Scholarship Repository

University of Minnesota Law School

Articles

Faculty Scholarship

1990

\title{
The United States-Dakota War Trials: A Study in Military Injustice
}

Carol Chomsky

University of Minnesota Law School, choms001@umn.edu

Follow this and additional works at: https://scholarship.law.umn.edu/faculty_articles

Part of the Law Commons

\section{Recommended Citation}

Carol Chomsky, The United States-Dakota War Trials: A Study in Military Injustice, 43 STAN. L. REV. 13 (1990), available at https://scholarship.law.umn.edu/faculty_articles/226.

This Article is brought to you for free and open access by the University of Minnesota Law School. It has been accepted for inclusion in the Faculty Scholarship collection by an authorized administrator of the Scholarship Repository. For more information, please contact lenzx009@umn.edu. 


\title{
The United States-Dakota War Trials: A Study in Military Injustice
}

\author{
Carol Chomsky*
}

Between September 28 and November 3, 1862, in southwestern Minnesota, nearly four hundred Dakota ${ }^{1}$ men were tried for murder, rape, and robbery. All but seventy were convicted, and 303 of these were condemned to die. ${ }^{2}$ After an official review of the trials, the sentences of thirty-eight were confirmed and, on December 26,1862, these thirty-eight were hanged in Mankato, Minnesota, in the largest mass execution in American history. On November 11, 1865, after three additional trials, two more Dakota followed them to the gallows.

The death penalty was not unusual in $1862,{ }^{3}$ and other American Indians have been tried and convicted in American courts. But the Dakota trials

* (C) 1990 by Carol Chomsky. Associate Professor, University of Minnesota Law School. I am grateful to numerous people who read earlier drafts of this article and offered many valuable suggestions: Gary Anderson, Milner Ball, Roger Buffalohead, Laura Cooper, Daniel Farber, Mary Louise Fellows, Philip Frickey, George Grossman, Robert Hudec, Robert Levy, Paul Murphy, Nell Newton, Suzanna Sherry, Avi Soifer, David Weissbrodt, and fo wiger. I am especially grateful to Chief Ernest Wabasha, Vernell Wabasha, Tribal Chair David Larsen, Dr. Chris Cavender, Reverend Gary Cavender, and James Whipple, members of the Mdewakanton Dakota community, for reading drafts and sharing their thoughts with me. Finally, Jaki Cottingham-Zierdt provided outstanding research assistance; more than that, she helped me understand the meaning and importance of the events I have described and led me to see them with new eyes. Steven Liss lived with this project daily for more than two years; he read not just one but every draft and was my best and most supportive critic.

Much of the source material for this article comes from primary documents contained in the collections of the National Archives and the Minnesota Historical Society. For ease of reference, I have used a standard set of abbreviations to refer to specific files on which I rely. These abbreviations appear in the Appendix beginning on page 96 infra.

I have, where possible, relied on events occurring before the trials and used sources and authorities in existence in 1862 in order to determine the legitimacy of the trials at the time they were conducted. However, when later events appear sufficiently part of a pattern to reflect attitudes in 1862 or where subsequent legal analysis seems particularly helpful-especially when little or no authority existed in 1862-I have made use of later materials. I have nonetheless tried to avoid anachronistic judgments.

1. The Dakota, along with the Lakota, comprise what is often called the Sioux Nation. In 1862, the Dakota occupied a small strip of land in southwestern Minnesota. See text accompanying and following note 5 infra.

2. Approximately ten Winnebagos were also tried, but acquitted. See note 87 infra. Oral tradition among the Dakota and other Indian nations suggests that members of other tribes were also tried and that some were executed. I have chosen, nonetheless, to refer to all the defendants as Dakota, except when discussing particular trials of members of other Indian nations, because the overwhelming majority of defendants were Dakota and the political ramifications of the trials and executions were felt primarily by that community. I do not mean to ignore the participation of members of other Indian nations in the events described here.

3. See generally Hugo AdAM Bedau, THe Death Penalty in AMERICA 3-9, 21-22 (1982). 
and executions were different. The Dakota were tried, not in a state or federal criminal court, but before a military commission. They were convicted, not for the crime of murder, but for killings committed in warfare. The official review was conducted, not by an appellate court, but by the President of the United States. Many wars took place between Americans and members of the Indian nations, but in no others did the United States apply criminal sanctions to punish those defeated in war.

The unique nature of these trials raises many questions. Why did this war, unlike others, result in trials? What meaning did the trials have for the Dakota and American communities? Were the proceedings conducted fairly and did they lead to just results? Was there historical precedent for conducting trials of this kind or legal authority for the jurisdiction exercised by the military court? What do these events suggest about the role of law in a pluralistic society in which all members do not share the same assumptions about justice and law?

The answers to these questions are of more than academic interest. Differing views about the war, the trials, and the executions-formative events in Dakota and Minnesota history-continue to divide the Dakota and nonDakota communities in Minnesota. Upon recommendation of some members of the Dakota community, the Governor of Minnesota declared 1987, the 125th anniversary of the war, to be the "Year of Reconciliation" in an effort to heal some of the remaining wounds. ${ }^{4}$ I hope that this detailed consideration of the trials will deepen the understanding of these events and contribute to the healing. By exploring the context of the trials and their impact on the Dakota and American communities, I also hope that this article will contribute to a greater understanding of the role and limits of law in a pluralistic society.

Part I of the article describes the war itself, the trials and official review of the proceedings, and the treatment of the accused and the rest of the Dakota community. The remainder of the paper explores the legitimacy of the trials and executions. Part II reviews the manner in which the trials were conducted. Part III questions whether, under American law, a military commission was the proper forum for trial of any offenses of which the Dakota might legitimately have been accused. Part IV examines the status of the Dakota in the context of the then-existing norms of warfare in international and American law to determine the standard by which the actions of the Dakota should have been judged. Part V reviews the evidence presented at the trials and considers whether it shows that any of the Dakota did, in fact, commit punishable offenses. Part VI addresses why this war, and no others, led to trials and executions.

The evidence demonstrates that the trials of the Dakota prisoners were objectionable in a number of respects. The speed of the proceedings, the nature of the evidence, and the identity of the judges all combined to pre-

4. Proclamation of Governor Rudy Perpich (Dec. 19, 1986) (on file with Stanford Law Review). 
clude judicious decisionmaking and to guarantee an unjust outcome. The commander who ordered the commission trials likely did not have the authority under prevailing statutes to convene the tribunal, and it is questionable whether a military commission had any lawful authority to try the Dakota.

More important, the commission tried the Dakota for the wrong crimes. Based on the historical and legal views prevailing in 1862 and the years that followed, the Dakota were a sovereign nation at war with the United States, and the men who fought the war were entitled to be treated as legitimate belligerents. The Dakota, therefore, should have been tried only on charges that they violated the customary rules of warfare, not for the civilian crimes of murder, rape, and robbery. Judged by those standards, few of the convictions are supportable. President Lincoln's commutation of all but thirtyeight death sentences may have been an effort to correct the trial verdicts to reflect the proper standard of responsibility, but the flaws in the proceedings make even his judgments questionable.

\section{The War and Its AFTERMath}

The Dakota people are part of what is often identified as the Sioux Nation, a group comprised of seven politically distinct tribes-the Seven Council Fires-that share family ties and a cultural value system, social organization, and language. The four tribes principally involved in the war-the Mdewakanton, Wahpekute, Sisseton, and Wahpeton-are among those that refer to themselves as Dakota. ${ }^{5}$

The Dakota people had once inhabited and controlled large areas of land in the upper Midwest. By 1862, however, the seven thousand Dakota occupied only a narrow strip of land-about one hundred twenty miles long and ten miles wide-along the Minnesota River in the southwestern part of Minnesota. The remainder of their land had been ceded to the United States in a series of treaties between 1805 and 1858 in return for cash payments and for money allocated to build facilities such as schools and mills. The Sisseton and Wahpeton tribes lived on the northwestern side of the reservation, with the Mdewakanton and Wahpekute tribes residing on the southeastern side. The reservation also contained two administrative centers established by the federal government, the Yellow Medicine or "Upper Sioux" Agency in the northwest and the Redwood or "Lower Sioux" Agency in the southeast.

\section{A. The War 6}

Despite the pledges of eternal peace and friendship in the treaties, by the

5. ElizABETH S. GROBSMTth, LAKOTA OF THE ROSEBUd 6-7 (1981). The other tribes among the Seven Council Fires are the Yankton, Yanktonai, and Teton. Id.

6. Until recently, the events described here were widely known as the "Sioux Uprising of 1862." Because "Sioux" is not the name by which the Dakota people refer to themselves and because "uprising" suggested an unjustified rebellion, the name more generally used now is the "Dakota Conflict." I have chosen instead to speak of these events as the "United States-Dakota War" to emphasize the international nature of the conflict. See Part IV infra. Since my purpose in this article 
summer of 1862 serious tension existed between the Dakota and American ${ }^{7}$ communities, fueled by a lengthening list of Dakota grievances against the United States. ${ }^{8}$ The treaties of 1851 had promised the Dakota lump sum payments in exchange for land, ${ }^{9}$ but eleven years later the Dakota people still had not received the funds. ${ }^{10}$ After 1851, American settlers began to move onto reservation land north of the Minnesota River; in the treaties of 1858 , a largely unwilling Dakota community was forced to relinquish that land. ${ }^{11}$ Restricted as they were to a small area, the Dakota could no longer support themselves in their traditional manner and so became increasingly dependent on the goods, services, and annuity payments promised in the treaties. When payments and delivery of goods were delayed, the Dakota suffered hunger and hardship. ${ }^{12}$

In 1857, the Indian Agent withheld the annuities in order to force the

is to explore the legal issues surrounding the war, not the war itself, the factual account that follows is brief. Additional background about the war is available from a variety of sources. Of primary importance is the oral history as told by the present-day members of the Dakota community. Other accounts by Dakota witnesses of the events are collected in Through Dakota EyEs: NARrative Accounts OF THE MINNESOTA INDIAN WAR OF 1862 (G. Anderson \& A. Woolworth ed. 1988) [hereinafter THROUGH DAKOTA EYES]. Several histories were published in the years immediately following the war, including CHARLEs S. BRYANT \& ABEL B. MURCH, A HISTORY OF THE GREAT MASSACRE BY THE SIOUX INDIANS IN MINNESOTA (2d ed. 1864 \& photo. reprint 1977) and ISAAC V.D. HEARD, HISTORY OF THE SIOUX WAR AND MASSACRES OF 1862 AND 1863 (1864 \& photo. reprint 1975). Other valuable sources include GARY CLAYTON ANDERSON, LITTLE CROW (1986); 1 BOARD OF COMMISSIONERS UNDER THE ACT OF APRIL 16, 1889, LEGISLATURE OF MINNESOTA, MINNESOTA IN THE CIVIL AND INDIAN WARS, 1861-1865, at 300-28, 347-69, 386-400, 416-38, 455$71,543-51,572-84,594-601,670-77,727-53$ (1890) [hereinafter MINNESOTA IN THE CIVIL AND INDIAN WARS]; KeNNETH CARLEY, THe SIOUX UpRISING of 1862 (2d ed. 1976); 2 WilliaM WATTS FOLWELl, A History OF MINNESOTA 109-264 (1926); ROY W. MEYER, HISTORY OF THE

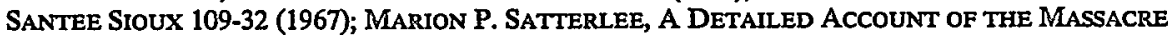
BY THE DAKOTA INDIANS OF MINNESOTA IN 1862 (1923).

7. Throughout this article, I most often refer to the men and women with whom the Dakota fought as "Americans" rather than as "whites" or "Minnesotans." I have chosen this terminology to emphasize the point, central to my thesis, that the Dakota fought as a sovereign nation against another nation, the United States. Most writers, both contemporaneous and modern, refer instead, to the "Indians" and "whites," emphasizing the racial division. Although the participants-especially the whites-may have viewed the conflict as a racial one, a full understanding of the war and its aftermath requires a shift in perspective in order to acknowledge the status of the Dakota as lawful belligerents. See Part IV infra.

8. See generally Through Dakota Eyes, supra note 6, at 19-33; C. Bryant \& A. MURCh, supra note 6, at 33-38; K. CARLEY, supra note 6, at 2-6; 2 W. FolwELL, supra note 6, at 212-41; I. HEARD, supra note 6, at 31-51; R. MEYER, supra note 6, at 109-16; M. SATTERLEE, supra note 6, at 2-9.

9. The Dakota signed two treaties in 1851: the Treaty of Traverse des Sioux, 10 Stat. 949 (1855), between the United States and the Sisseton and Wahpeton tribes, and the Treaty of Mendota, 10 Stat. 954 (1855), between the United States and the Mdewakanton and Wahpekute tribes.

10. See C. BRYANT \& A. MURCH, supra note 6, at 33-35. Most of the money was given directly to creditors, contrary to the treaty terms and to federal law. See id. at 35-38; R. MEYER, supra note 6 , at 80-81; note 15 infra and accompanying text.

11. See R. MEYER, supra note 6, at 103-08. Taoyateduta (Little Crow) lost much of his influence in the Dakota community because of his agreement to the Treaty of 1858 . See Big Eagle's Account, in Through DaKota EYeS, supra note 6, at 21, 23, 25; M. SATTERLEE, supra note 6, at 114-15; see also note 4i infra.

12. See Through Dakota Eyes, supra note 6, at 20; $\mathrm{K}$. CARLey, supra note 6, at 5; 1 . HEARD, supra note 6, at 44; M. SATTERLEE, supra note 6, at 7. 
Dakota to pursue and capture an outlaw band of Dakota, ${ }^{13}$ thereby punishing the whole group for the actions of a few individuals who were not part of the community. Later, the Agent began to divide the payments unequally among the Dakota to reward those who adopted American ways at the expense of those who maintained a traditional Dakota lifestyle. ${ }^{14}$ When annuities were distributed, the Agent often paid most or all of the money directly to the traders for goods already sold to the Dakota on credit, based on unverified claims that were probably padded and were viewed with great-and justified-suspicion by the Dakota. ${ }^{15}$

In the summer of 1862 , the annuity payments were late once again. $\mathrm{Ru}$ mors spread that, because of the American government's preoccupation with the Civil War, payments might be made in paper money rather than the stipulated gold, or might not be made at all. ${ }^{16}$ The traders were reported to have said that the payments, if ever made, would be the last. ${ }^{17}$ Because of past abuses by the traders, the Dakota made plans to demand payment of the annuities directly to the people rather than to the traders; when the traders learned of this, they refused to sell any more provisions on credit, though many of the Dakota were starving. ${ }^{18}$ When Indian Agent Thomas Galbraith met with the traders to try to resolve the impasse, Andrew Myrick, the spokesman for the traders, responded, "So far as I am concerned, if they are hungry, let them eat grass." 19

Thus, longstanding grievances over treaty violations and trader abuses, combined with worsening economic conditions and pressures created by the American drive to assimilate the Dakota, set the stage for war. An incident on Sunday, August 17, 1862, finally precipitated the conflict. Four young Dakota men returning from a hunting expedition killed five American settlers on two homesteads in Acton, Minnesota. ${ }^{20}$ The attack, apparently un-

13. G. ANDERSON, supra note 6, at 82-87; C. BRYANT \& A. MURCH, supra note 6, at 40-42; K. CARLEY, supra note 6, at 5; R. MEYER, supra note 6, at 100; M. SATTERLEE, supra note 6, at 6.

14. See Through DaKota EYES, supra note 6, at 19-20; Big Eagle's Account, supra note 11, at 21, 26; I. HEARD, supra note 6, at 43.

15. See I. HEARD, supra note 6, at 31, 33-34; R. MEYER, supra note 6, at 110-11 \& n.3. This kind of trader theft was rampant throughout the country. See DAVID A. NICHOLS, LINCOLN AND the Indians: Crvil War Policy and Polmics 5-24 (1978); Robert H. Utley, The Indian FRONTIER OF THE AMERICAN WEST 1846-1890, at 45-46, 78 (1984).

16. Big Eagle's Account, supra note 11, at 27; R. MEYER, supra note 6, at 112-13.

17. J.E. De C. Sweet, Mrs. J.E. de Camp Sweet's Narrative of Her Captivity in the Sioux Outbreak of 1862, in 6 COLLECTIONS OF THE MiNNESOTA Historical SOCIETY 354, 357 (1894).

18. Robert Hakewaste's Testimony, in Through Dakota Eyes, supra note 6, at 31-32; C. BRYANT \& A. MURCH, supra note 6, at 53 (quoting Major Galbraith); K. CARLEY, supra note 6, at 6; I. HEARD, supra note 6, at 48-49; M. SATTERLEE, supra note 6, at 9.

19. R. MEYER, supra note 6, at 116. Myrick was one of the first casualties of the war. When his body was found, his mouth had been stuffed with grass. Id. at 117; see also Big Eagle's Account, supra note 11, at 55-56; Joseph Coursolle's Story, in Through Dakota EYss, supra note 6, at 57, 59; K. CARLEY, supra note 6, at 11; M. SATTERLEE, supra note 6, at 9.

20. Most of the stories about the events at Acton come from the writings of non-Indian historians. K. CARLEY, supra note 6, at 7-9; 2 W. FOLWELL, supra note 6, at 415-17; 1. HEARD, supra note 6, at 52-56; R. MEYER, supra note 6, at 114-15. David Larsen, current Tribal Chair of the Lower Sioux Mdewakanton Community, suggests that all of these accounts are inaccurate, but that they have been repeated so many times that even some members of the Dakota community report them as though they were fact. Moreover, the focus on these reportedly unprovoked killings allows the spark 
provoked by any immediate act, was fueled by the increasing tensions between the Dakota and the American settlers. If serious grievances against the Americans had not built up over the previous several years, the Dakota might have delivered the four men to the Americans for punishment, and peace would have prevailed, at least temporarily. ${ }^{21}$ The incident then might have remained an isolated occurrence, one of many so-called "Indian depredations" on the frontier.

Instead, many of the young Dakota men urged their leaders to initiate war against the American settlers to try to drive them from the Minnesota Valley. Councils were held among the Dakota that night. ${ }^{22}$ Many of the leaders expressed reluctance or even opposition to war. Some felt sympathy with or had ties to the American community; others realized that a war against the superior numbers and firepower of the Americans could not be won, even though many of the Minnesota men had been sent east to fight the Civil War. ${ }^{23}$ The young men, however, hoped to recapture their lost land, drive the American settlers away, and return to their traditional way of life. ${ }^{24}$ Many also believed that the Americans would stop payment of the annuities and take vengeance upon the whole tribe in retaliation for the Acton killings, particularly because women were among the victims. They argued that the Dakota should strike first rather than wait for the inevitable. ${ }^{25}$ The Council decided on war.

The fighting began the next morning when a group of Dakota attacked the Redwood (Lower) Agency, a settlement populated by traders, the Indian agent, various government personnel and their families, farmer-Indians, and some other mixed and full bloods. ${ }^{26}$ Thirteen Americans were killed in the attack on the Agency, seven more were killed while fleeing from the settle-

that ignited the war to overshadow the long list of grievances that were the true cause of the conflict. Interview with David Larsen, Tribal Chair of the Lower Sioux Mdewakanton Community, in Morton, Minn. (July 23, 1989).

21. R. MEYER, supra note 6, at 115; cf. G. ANDERSon, supra note 6, at 85 (surrender by Sissetons of a tribal member who had stabbed American soldier). One observer reported that two of the Dakota who killed at Acton were shot in punishment by their own people. Good Star Women's Recollections, in Through DAKOTA EYEs, supra note 6, at 52-53.

22. As with other decisions, the decision to go to war would normally be made in Council. See text accompanying notes 436-437 infra. As reported by Wambditanka (Big Eagle), everyone at Shakopee's village heard of the killings at Acton, and the young men responsible for the killings were then taken to see Taoyateduta. A Council was held at Taoyateduta's village, and war was declared. Big Eagle's Account, supra note 11, at 35-36; see also K. CARLEY, supra note 6, at 10-12; R. MEYER, supra note 6 , at 117.

23. K. CARLEY, supra note 6, at 10-11; R. MEYER, supra note 6, at 117-18.

24. G. ANDERSON, supra note 6, at 130-31.

25. See Big Eagle's Account, supra note 11, at 35-36; see also G. ANDERson, supra note 6, at 130-31. There was reason for the Dakota to fear general retaliation against the tribe. In 1857, a renegade band of Wahpekutes led by Inkpaduta had killed more than forty Americans in Iowa in what became known as the Spirit Lake Massacre. These Wahpekutes were already outcasts of the tribe, having fled west to the Missouri River Valley after killing the recognized chief of the Wahpekutes in the 1840s. Nonetheless, the Americans insisted that the Dakota had responsibility for capturing and punishing Inkpaduta and withheld annuity payments to force them to do so. See note 13 supre and accompanying text.

26. See K. CARLeY, supra note 6, at 12-14; 2 W. Folwell, supra note 6, at 109-11; R. MEYER, supra note 6, at 117. 


\section{ment, and ten were captured. ${ }^{27}$}

Forty-seven settlers escaped from Redwood to Fort Ridgely, a federal army outpost garrisoned by Minnesota volunteer regiments that the United States government had mustered into federal service while the regular troops fought in the Civil War. ${ }^{28}$ After hearing the news of the attack, Captain John S. Marsh, the commander at Fort Ridgely, set out for the Redwood Agency with forty-six enlisted men and an interpreter. Despite warnings from fleeing settlers that he would be outnumbered, he continued toward the Agency. The Dakota attacked him and his men at the Redwood Ferry, killing twenty-four. The remaining soldiers retreated with some difficulty to Fort Ridgely. ${ }^{29}$

In the days that followed, the Dakota fought several different kinds of engagements with Americans. The Dakota fought two battles at New Ulm, a German settlement in a strategically significant lecation in the Minnesota Valley. ${ }^{30}$ In both battles, the town was defended by men who had volunteered to serve in the fight against the Dakota; ${ }^{31}$ these "citizen-soldiers" fought to protect themselves and more than a thousand women, children, and unarmed men barricaded in the center of town. ${ }^{32}$ Other battles involved only the military: ${ }^{33}$ attacks on Fort Ridgely, an attack on a party of soldiers at Birch Coulee, skirmishes in Meeker County, and the final battle at Wood Lake. ${ }^{34}$ The American forces were led by Colonel Henry H. Sibley, appointed on August 19 by Minnesota Governor Ramsey to be commander of the volunteer forces and named on September 29 by President Lincoln to be Brigadier General of United States Volunteers in charge of the U.S. Military District of Minnesota. ${ }^{35}$

27. K. CARLEY, supra note 6 , at 14.

28. See L.F. Hubbard, Narrative of the Fifth Regiment, in MINNESOTA IN THE CIVIL AND INDIAN WARS, supra note 6, at 243-44.

29. K. CARLeY, supta note 6, at 15-16; 2 W. FolWell, supra note 6, at 112-14; R. MEYER, supra note 6, at 118; Hubbard, supra note 28 , at 248-50.

30. See K. CARLEY, supra note 6, at 32-39; R. MEYER, supra note 6, at 118-19.

31. See J.H. Baker, Narrative of the Tenth Regiment, in MinNesota IN THE CIVIL AND INDIAN WARS, supra note 6, at 455, 455-56; Chas. E. Flandrau, The Indian War of 1862-1864, and Following Campaigns in Minnesota, in MINNESOTA IN THE CIVIL AND INDIAN WARs, supra note 6, at 727, 731-32. See generally 2 W. FoLWELL, supra note 6, at 135-44.

32. I. HEARD, supra note 6, at 80; see also K. CARLEY, supra note 6, at 33-39; 2 W. FolWELL, supra note 6 , at 134 .

33. The American soldiers were members of Minnesota volunteer regiments that were mustered into federal service as part of the Civil War effort. See C. C. Andrews, Narrative of the Third Regiment, in MINNESOTA IN THE CIVIL AND INDIAN WARS, supra note 6, at 147, 147; Hubbard, supra note 28, at 243-44; Charles W. Johnson, Narrative of the Sixth Regiment, in MinNesota in THE CIVII AND INDIAN WARS, supra note 6, at 300, 300-01; James T. Ramer, Narrative of the Seventh Regiment, in MINNESOTA IN THE CIVIL AND INDIAN WARS, supra note 6, at 347, 347-51. Most of Sibley's initial cavalry were volunteers from the Minneapolis-St. Paul area, organized as Northrup's Mounted Volunteers. Although Sibley tried to keep them in his command, most returned to their homes after the second battle of Fort Ridgely. M. SATTERLEE, supra note 6, at 12122.

34. Flandrau, supra note 31 , at 733-34, 736-40, 743-46; K. CARLEY, supra note 6, at 28-30, 4144, 62-63; 2 W. FolWeLL, supra note 6, at 131-32, 179-81; R. MEYER, supra note 6, at 119.

35. General Officers, in MINNESOTA IN THE CIVIL AND INDIAN WARS, supra note 6, at 701, 712; K. CARLEY, supra note 6, at 30-31, 67; 2 W. FolWELL, supra note 6, at 147-48. Sibley, elected 
From the outset the Dakota also attacked other American settlements and settlers who had not yet taken shelter behind the fortifications being constructed by the citizens of the towns. ${ }^{36}$ Many of the settlers were reportedly unarmed and taken by surprise. ${ }^{37}$ In most cases, the Dakota killed the men and took the women and children prisoners. ${ }^{38}$ Wild stories of mutilation by the Dakota in these encounters spread among the settlers, but historians have concluded that these reports were probably exaggerations of isolated instances of atrocities. ${ }^{39}$

Meanwhile, the disagreements evident at the initial Council continued, dividing those Dakota who supported the war from those who opposed it. The Sisseton and Wahpeton located at the Yellow Medicine (Upper) Agency at first declined to join the war, and some of them helped American settlers and missionaries escape attacks on the Agency.40 Some Mdewakanton opposed continuing the war and urged return of the women and children hostages. Colonel Sibley contacted Taoyateduta (Little Crow), ${ }^{41}$ the reluctant leader of the war, ${ }^{42}$ to attempt negotiation, but Sibley demanded the return of the hostages before beginning any discussions. ${ }^{43}$ The Dakota held Coun-

the first Governor of Minnesota in 1857 (by defeating Ramsey), had no previous military experience, but he knew the Dakota well from years of hunting and trading with them. 2 W. FoLweLL, supra note 6 , at $3,147-48$.

36. See K. CARLEY, supra note 6, at 45-50; 2 W. FolWELL, supra note 6, at 110-11, 115-16, 157-62; I. HEARD, supra note 6, at 68-71.

37. K. CARLeY, supra note 6, at 21-22; 2 W. Folwell, supra note 6 , at 123-24.

38. R. MEYER, supra note 6 , at 120.

39. Id. Meyer concludes that the stories of Dakota atrocities "can no longer be accepted by sober scholarship." Id. Carley suggests that when bodies were later recovered, "[i]t seems probable that the condition of the bodies, which had lain in the hot sun for nearly two weeks, gave rise to some false charges of mutilation." $K$. CARLEY, supra note 6 , at 42 . The doctor who accompanied one of the burial expeditions denied the existence of mutilations. R. MEYER, supra note 6, at 120 . Meyer also notes that not all the atrocities were committed by the Dakota. Id. On the other hand, some "mutilation" would occur from the use of weapons like the hatchet, knife, and war club, all standard parts of the Dakota arsenal. In addition, purposeful mutilation might have been directed at special enemies, such as the traders, to humiliate those who had treated the Dakota with particular disrespect. See Anthony McGinnis, Strike \& Retreat: Intertribal Warfare and the Powder River War, 1865-1868, 30 MONT. MAG. W. Hist. 30, 38 (1980); note 19 supra (treatment of Andrew Myrick). Some of the reports, then, were probably accurate, but wild rumors far exceeded the reality.

40. Samuel J. Brown's Recollections, in Through Dakota Eyes, supra note 6, at 169, 169-70; Gabriel Renville's Memoir, in Throvgh Dakota Eyes, supra note 6, at 186, 186-88; $\mathbb{K}$. CarLeY, supra note 6, at 17-20; 2 W. FoLWELL, supra note 6, at 116-20; I. HEARD, supra note 6, at 74-77.

41. Wherever possible, I have used the English transliteration of Dakota names for individual Dakota people. Originally, the Dakota language was exclusively oral, but early missionaries thought that it should have a written form as well. Transliterations from different sources may vary in spelling. When an individual has become generally known by an English translation, I have also included the English name upon the first use of the Dakota name.

42. Initially reluctant to participate in the war, Taoyateduta took leadership of the soldiers despite his belief that the war could not be won. Anderson suggests that Taoyateduta made the decision as a matter of honor-to give his life and die with the soldiers-as well as, perhaps, to regain some of the influence he had lost as a result of his support for the Treaties of 1858 and his accommodation to American ways. G. ANDERSON, supra note 6, at 133-34; see also Big Eagle's Account, supra note 11, at 23, 25; Little Crow's Speech, in Through DAKOTA EYES, supra note 6, at $39,40-42$.

43. Flandrau, supra note 31, at 741-42; see also K. CARLEY, supra note 6, at 61; I. HEARD, supra note 6, at 148, 150; Letter from Col. Henry Sibley to Mrs. Henry Sibley (Sept. 8, 1862), in Sibley Papers, roll 11, frame 666, MHS [microfilm]. 
cils to decide whether to negotiate. 44 Taoyateduta was loath to do so, believing that no mercy would be shown the Dakota, but two other leaders, Chiefs Wabasha and Taopi, 45 who had opposed the war from the outset, contacted Sibley to discuss a surrender. ${ }^{46}$

On September 23, scarcely a month after the war had begun, the Dakota fighting men returned to camp after the battle at Wood Lake to discover that the Dakota who opposed continuation of the war had taken control of the white captives. Support for the war was rapidly diminishing, and those who wished to continue fighting or opposed surrender moved out of camp with their families and belongings, leaving the others behind. Among those who fled north were three of the leaders of the war effort, Taoyateduta, Shakopee (Little Six), and Wakanozanzan (Medicine Bottle). The remaining Dakota then sent word to Sibley that he and his soldiers could "come up," which he proceeded to do. On September 26, Sibley set up Camp Release opposite the Dakota camp. ${ }^{47} \mathrm{He}$ entered the Dakota camp later that day and took some 1200 Dakota men, women, and children into custody. About 800 more surrendered in small groups over the next several weeks. ${ }^{48}$

In thirty-seven days of fighting, 77 American soldiers, 29 citizen-soldiers, approximately 358 settlers, ${ }^{49}$ and an estimated 29 Dakota soldiers ${ }^{50}$ had

44. See Gabriel Renville's Memoir, supra note 40, at 186-91; Paul Mazakutemani's Statement, in THROUGH DAKOTA EYES, supra note 6, at 194, 195-98; Samuel J. Brown's Recollections, supra note 40, at 175; Thomas A. Robertson's Reminiscences, in Throvgr DAKOTA EYEs, supra note 6, at 177, 178-79, 181-82; Victor Renville's Account, in ThROUGH DAKOTA EYEs, supra note 6, at 192, 192-94; 1. HEARD, supra note 6, at 151-52; R. MEYER, supra note 6, at 122; THROUGH DAKOTA EYEs, supra note 6 , at 168 . Heard quotes at length the speech of Hdainyanka, Wabasha's son-inlaw, in favor of continuing the war:

I am for continuing the war, and am opposed to the delivery of the prisoners. I have no confidence that the whites will stand by any agreement they make if we give them up. Ever since we treated with them their agents and traders have robbed and cheated us. Some of our people have been shot, some hung; others placed upon floating ice and drowned; and many have been starved in their prisons. It was not the intention of the nation to kill any of the whites until after the four men returned from Acton and told what they had done. When they did this, all the young men became excited, and commenced the massacre. The older ones would have prevented it if they could, but since the treaties they have lost all their influence. We may regret what has happened but the matter has gone too far to be remedied. We have got to die. Let us, then, kill as many of the whites as possible, and let the prisoners die with us.

I. HEARD, supra note 6 , at 151-52.

45. Both men held important positions in the Mdewakanton community. Wabasha was the principal chief of the Mdewakantons. Big Eagle's Account, supra note 11, at 25; K. CARLEY, supra note 6, at 12. Taopi was head of the farmer-Indians, appointed by Indian Agent Galbraith. Big Eagle's Account, supra note 11, at 93; R. MEYER, supra note 6, at 121.

46. R. MEYER, supra note 6 , at 121-22; 2 W. FolWELL, supra note 6, at 172-73; see also Thomas A. Robertson's Reminiscences, supra note 44, at 183.

47. K. CARLEY, supra note 6, at 64-65; 2 W. Folwell, supra note 6, at 182-85; see also Letter from Col. Henry Sibley to Mrs. Henry Sibley (Sept. 27, 1862), in Sibley Papers, roll 11, frame 670, MHS [microfilm].

48. K. CARIEY, supra note 6, at 67; see also I. HEARD, supra note 6, at 188; Letters from Col. Henry Sibley to Mrs. Henry Sibley (Oct. 5, Oct. 10, and Oct. 19, 1862), in Sibley Papers, roll 11, frames 672-74, MHS [microfilm].

49. Accounts vary regarding the number of settlers killed. Marion Satterlee, a journalist who has been called the "most thorough student" of casualties in the war, K. CARLEY, supra note 6, at 1 n. ${ }^{*}$, reported 413 settlers killed. M. SATTERLEE, supra note 6 , at 124 . Twenty-nine of the individuals 
been killed.

\section{B. The Trials}

When deciding whether to surrender themselves and their captives, $\mathrm{Da}$ kota leaders had expressed concern about the treatment their people would receive from the Americans, ${ }^{51}$ but Sibley had assured them that he sought only to punish the individuals who had committed the "murder and outrages upon the white settlers."52 As soon as Sibley gained custody of the 1200 Dakota at the camp, he took steps to initiate such punishment. On September 27 he reported to his commanding officer, Major General John Pope, ${ }^{53}$ that he had appointed a three-member military commission to examine all the Indian and mixed-blood men and to "sift the antecedents" of each man "so that if there are guilty parties among them they can be arrested and properly dealt with." 54 At this point, Sibley perhaps saw the Commission as what would formally be called a "court of inquiry," generally designed to collect information for later use in prosecution or other proceedings, but with no authority to enter judgments and sentences. ${ }^{55}$

Whatever Sibley's original intention, however, the order he issued on

included in Satterlee's total were citizen-soldiers killed in the battles at New Ulm and Birch Coulee. Id. at 65-66, 120. Twenty-six others died under circumstances not directly connected with the fighting in 1862: fifteen of them were killed in 1863, two in 1864, and six in 1865, id. at 59-61; one died, without having been wounded, six months after the war, id. at 36, and two "left [their homes] for a months [sic] trip to the Missouri river, on June 2nd, but were never heard from," $i d$. at 50 . Kenneth Carley, a historian of the War, variously lists 447 (based on Satterlee's account, including military losses) and 500 (based on Governor Ramsey's estimate). K. CARLEY, supra note 6, at $1 \mathrm{n} .{ }^{\circ}$.

50. M. SATTERLEe, supra note 6, at 107-08. But see $\mathbb{K}$. CARLEY, supra note 6, at $1 \mathrm{n} .{ }^{*}(21$ Dakota killed).

51. Those who did not surrender shared that concern. They made their decision to flee in part based on their belief that the Americans would retaliate against all Dakota for the killing. See, eg., Gabriel Renville's Memoir, supra note 40, at 189-90. Indeed, the war itself was fought partly because many of the young men argued that the entire nation would suffer for the actions of the men who killed the settlers in the incident that sparked the war. See note 25 supra and accompanying text.

52. Letter from Col. Henry Sibley to Those of the Half-Breeds and Sioux Indians Who Have Not Been Concerned in the Murder and Outrages upon the White Settlers (Sept. 13, 1862), reprinted in 13 UNITED STATES DEPARTMENT OF WAR, THE WAR OF THE REBELlion: A COMPILATION OF THE OFFICIAL RECORDS OF THE UNION AND CONFEDERATE ARMIES, SERIES I 632 (1885) [heteinafter WAR of THE REBellion, SER. I]; accord, Letter from Col. Henry Sibley to Ma-za-ka-tame [Mazakutemani], Toopee [Taopi], and Wa-ke-nan-nan-te (Sept. 24, 1862), reprinted in id. at 666-67; Letter from Col. Henry Sibley to Ta-tanka-nazin (Sept. 24, 1862), reprinted in id. at 667.

53. Major General John Pope was placed in command of the newly created Military Department of the Northwest on September 6, 1862. K. CARLEY, supra note 6, at 60. Pope had suffered a major defeat in the second Battle of Bull Run just a week earlier, resulting in his removal from command. He was "a major-general without a job" and was sent, in some disgrace, to direct the fight against the Dakota, in response to repeated requests from Governor Ramsey for federal assistance. Richard N. ElLIS, General Pope AND U.S. INDIAN Policy 6-7 (1970).

54. Letter from Col. Henry Sibley to Maj. Gen. John Pope (Sept. 27, 1862), reprinted in 13 WAR OF THE Rebellion, SER. I, supra note 52, at 679, 680; see Order No. 54, issued at Camp Release (Sept. 27, 1862), in Sibley Papers, roll 32, frame 109, MHS [microfilm]. The order named Colonel Crooks, Lieutenant-Colonel Marshall, and Captain Grant to a commission "for the purpose of examining into the participation of certain Indians and half breeds in the late murders and robberies committed on this frontier." Id. All three men served on the expanded commission appointed on September 28. See note 56 infra and accompanying text.

55. See note 308 infra. 
September 28 went beyond his reported plans. The order appointed a fivemember military commission and authorized it to "try summarily the $\mathrm{Mu}$ latto, and Indians, or mixed bloods, now prisoners, or who may be brought before them ... and pass judgement upon them, if found guilty of murders or other outrages upon the Whites, during the present State of hostilities of the Indians." 56 The Commission was to conduct trials and pass judgment, not simply to investigate. Sibley wrote to Pope again on the 28th, reporting that he had seized sixteen men in the camp suspected of being participants in the "late outrages" and appointed a commission to try them. ${ }^{57}$ The guilty, he said, would be executed immediately, despite his expressed doubt whether such action was within his authority. ${ }^{58}$ "An example is . . imperatively necessary," Sibley wrote, "and I trust you will approve the act, should it happen that some real criminals have been seized and promptly disposed of." 59

There seemed little question that Pope would approve Sibley's actions. Sibley's letter of September 28 to Pope crossed with one from Pope to Sibley, in which Pope disparaged the ability of the Dakota to live up to any agreements, cautioned Sibley against making any treaties with them, and concluded:

The horrible massacres of women and children and the outrageous abuse of female prisoners, still alive, call for punishment beyond human power to inflict. There will be no peace in this region by virtue of treaties and Indian faith. It is my purpose utterly to exterminate the Sioux if $I$ have the power to do so and even if it requires a campaign lasting the whole of next year. Destroy everything belonging to them and force them out to the plains, unless, as I suggest, you can capture them. They are to be treated as maniacs or wild beasts, and by no means as people with whom treaties or compromises can be made. 60

56. Order No. 55, issued at Camp Release (Sept. 28, 1862), reprinted in Trial Transcripts (contained in each transcript).

57. Letter from Col. Henry Sibley to Maj. Gen. John Pope (Sept. 28, 1862), reprinted in 13 WAR OF THE REBELLION, SER. I, supra note 52, at 686-87. The same statement appears in letters sent by Sibley from Camp Release to both his wife and Charles Flandrau on September 28. Letter from Col. Henry Sibley to Mrs. Henry Sibley (Sept. 28, 1862), in Sibley Papers, roll 11, frames 67071, MHS [microfilm]; Letter from Col. Henry Sibley to Col. Charles Flandrau (Sept. 28, 1862), in id. at roll 11, frame 688. Sibley's letter to Flandrau was reprinted in part, with an incorrect date of September 25, 1862, in Flandrau, supra note 31, at 746.

58. Letter from Col. Henry Sibley to Maj. Gen. John Pope (Sept. 28, 1862), reprinted in 13 WAR OF THE REBELLION, SER. I, supra note 52, at 687. Sibley expressed similar doubts in his letter to Flandrau: "If found guilty, they will be forthwith executed, although perhaps it will be a stretch of my authority. If so, necessity must be my justification." Letter from Col. Henry Sibley to Col. Charles Flandrau (Sept. 28, 1862), in Sibley Papers, roll 11, frames 670-71, MHS [microfilm].

59. Letter from Col. Henry Sibley to Maj. Gen. John Pope (Sept. 28, 1862), reprinted in 13 WAR OF THE ReBellion, SER. I, supra note 52, at 687.

60. Letter from Maj. Gen. John Pope to Col. Henry Sibley (Sept. 28, 1862), reprinted in 13 WAR OF THE REBELLION, SER. I, supra note 52, at 685-86. Pope's sentiments were shared by others on the scene. In his message to the state legislature on September 9, Governor Ramsey had called for the extermination of the Dakota or their removal from the state. Message of Governor Ramsey to the Legislature of Minnesota (Sept. 9, 1862) at 12, reprinted in MINNESOTA LegisLATURE, EXECUTIVE DOCUMENTS OF THE STATE OF MINNESOTA FOR THE YEAR 1862 (1863). 
The five members of the Commission Sibley appointed were LieutenantColonel William R. Marshall, Colonel William Crooks, Captain Hiram P. Grant, Captain Hiram S. Bailey, and Lieutenant Rollin C. Olin, the last designated as Judge Advocate. ${ }^{61}$ Sibley appointed Adjutant Isaac Heard of McPhail's Mounted Rangers as Recorder. ${ }^{62}$ All six men appointed to the Commission had fought in the war with the Dakota.

The trials began immediately on September 28,63 the day Sibley issued the Order. The charges were based on information collected by Reverend Stephen Riggs, a missionary from the American Board of Commissioners for Foreign Missions, who had worked with the Dakota since 1837. Riggs,

61. William Marshall was the most prominent member of the Commission. Before joining the Army, he had been a member of both the Wisconsin and Minnesota legislatures and had helpad to organize the Republican Party in the Minnesota Territory. Daniel S.B. Johnston, Minnesota Journalism from 1858-1865, in 12 COLlections OF THE MINNESOTA HISTORICAI SOCIETY 183, 219 (1908). One prominent Minnesota historian noted that "Minnesota had no citizen who more ardently loved justice and freedom." 1 WILLIAM WATTS FolWELL, A HISTORY OF MINNESOTA 375 (1921). Marshall, a pioneer newspaperman, founded the St. Paul Press on January 1, 1861, and remained its editor until his enlistment in the Army in 1862. Johnston, supra, at 219. He led five companies in the decisive battle at Wood Lake. Report from Col. Henry Sibley to Gov. Alexander Ramsey (Sept. 23, 1862), reprinted in 13 WAR OF THE REBELLION, SER. I, supra note 52, at 278-79. He was later to play an important role in several Civil War battles, and left the service a Brigadier General. JAMES H. BAKER, William Rainey Marshall, in 13 Collections of the MinNesota HISTORICAL SOCIETY 150, 152-53 (1908); Johnston, supra, at 220. Returning home a hero, he was elected Governor of Minnesota in the fall of 1865, and served until 1870. Id.

William Crooks, a graduate of West Point, commanded the 6th Minnesota Regiment at the battles of Birch Coulee and Wood Lake. 2 W. Folwell, supra note 6, at 150-55, 177-82. He later served as both a Representative and a Senator in the Minnesota State Legislature. Memorials of Deceased Members, 1905-1908, in 12 COLLECTIONS OF THE MINNESOTA HISTORICAL SOCIETY 767, 794 (1908).

The other members of the hearing panel were less well known. Captain Grant acted under Marshall's command at Wood Lake. Report from Col. Henry Sibley to Gov. Alexander Ramsey (Sept. 23, 1862), reprinted in 13 WAR OF THE REBELLION, SER. I, supra note 52, at 279. He commanded Company A of the 6th Minnesota Regiment in the Battle of Birch Coulee, selecting the camp location that proved disastrous for the Army. K. CARLEY, supra note 6, at 41-44. Grant took charge of the entire command after his superior officers were wounded. M. SATTERLEE, supra note 6, at 64. First Lieutenant Olin was second-in-command of the 3rd Minnesota Regiment at the batele of Wood Lake. Andrews, supra note 33, at 158-61. He later was named Assistant Adjutant General of the District of Minnesota.

Marshall sat as a member of the Commission for only 29 cases. I. HEARD, supra note 6, at 251. On October 15, Marshall was replaced by Major George Bradley of the 7th Minnesota Regiment, id., which had relieved the men under siege at Birch Coulee and fought in the Battle of Wood Lake. See Ramer, supra note 33, at 350-52. Isaac Heard reports Bradley to have been "rated among the first lawyers of the state." I. HEARD, supra note 6, at 268. Marshall, meanwhile, was placed in command of several companies of soldiers assigned to pursue a group of fleeing Dakota. Ramer, supra note 33 , at 352 .

62. Isaac V.D. Heard was a lawyer from St. Paul who had been for many years the prosecuting attorney of Ramsey County and was on Colonel Sibley's stafif at the time of the trials. Flandrau, supra note 31, at 747; 2 W. FolWELI, supra note 6, at 192 n.3. Heard later became the primary contemporary historian of the United States-Dakota War, authoring in 1864 a book entitled History of the Sioux War and Massacres of 1862 and 1863 (I. HEARD, supra note 6). Folwell states that the duties of the office of Judge Advocate were mainly performed by Isaac Heard, "erroneously" mentioned as the Recorder of the Commission. 2 W. Folwell, supra note 6, at 192 n.3. The trial transcripts, however, do list Heard as Recorder, see Trial Transcripts (early cases), a position associated with a court of inquiry rather than with a military commission or court martial. See note 308 infra.

63. See Trial Transcripts, Case Nos. 1-5, 7, 14-22, 27. 
whom Heard described as "the Grand Jury of the court," had assembled in a tent the mixed-bloods and "others possessed of means of knowledge" of the war and had interrogated them to determine who was implicated in the fighting. ${ }^{64}$

It appears that the Commission tried sixteen men on that first day. ${ }^{65}$ Ten were convicted and sentenced to be hanged; six were acquitted and apparently released. ${ }^{66}$ Sibley continued to apprise General Pope of the progress of the trials and his plans for those convicted, ${ }^{67}$ and Pope, in turn, informed his own superior, General Halleck. 68 On October 2, Pope responded to Sibley that he "altogether approve[d] of executing the Indians who have been concerned in these outrages" and reiterated his distrust of all the Indians, whether or not they professed to be friendly. ${ }^{69}$ Indeed, he later warned Sibley that he would not sanction any treaty with the Indians ${ }^{70}$ and that he had enough troops to "exterminate them all, if they furnish the least occasion for it."71

64. I. HEARD, supra note 6, at 251. Heard said Riggs was eminently qualified for this role because of his familiarity with the Dakota language and because of his long acquaintance with the Dakota, their character, and their habits, which "enabl[ed] him to tell almost with certainty what Indians would be implicated and what ones not, either from their disposition or their relatives being engaged." Id.

65. The trial transcripts contain a separate written charge for each of the 392 trials. Fifteen of the charges were dated September 28-cases numbered 1-5, 7, 14-18, 20-22, and 27-and one, case number 19, was dated simply September. As the case numbers of those so dated were not continuous, it is possible that not all of these trials were actually held on September 28, but that the date was copied incorrectly from earlier charges used as models for later trials. That error is particularly likely in case number 27, in which the charge contained the name of a different defendant, which was crossed out by hand with another name substituted. For lack of better information, however, I have relied upon the dates written on the transcripts to specify the dates of trials.

66. The six acquittals are reported as Case Nos. 7, 16, 17, 20, 21, and 27.

67. See Letter from Col. Henry Sibley to Maj. Gen. John Pope (Sept. 30, 1862), reprinted in 13 WAR OF THE REBELIION, SER. I, supra note 52, at 694; Letter from Col. Henry Sibley to Maj. Gen. John Pope (Oct. 3, 1862), reprinted in id. at 707, 708; Letter from Col. Henry Sibley to Maj. Gen. John Pope (Oct. 4, 1862), reprinted in id. at 710; Letter from Col. Henry Sibley to Maj. Gen. John Pope (Oct. 5, 1862), reprinted in id. at 711, 712; Letter from Brig. Gen. Henry Sibley to Maj. Gen. John Pope (Oct. 7, 1862), reprinted in id. at 717.

68. See Letter from Maj. Gen. John Pope to Gen.-in-Chief Henry Halleck (Oct. 2, 1862), reprinted in 13 WAR OF THE REBELLION, SER. I, supra note 52, at 705, 706; Letter from Maj. Gen. John Pope to Gen.-in-Chief Henry Halleck (Oct. 7, 1862), reprinted in id. at 716; Letter from Maj. Gen. John Pope to Gen.-in-Chief Henry Halleck (Oct. 9, 1862), reprinted in id. at 722; Letter from Maj. Gen. John Pope to Gen.-in-Chief Henry Halleck (Oct. 10, 1862), reprinted in id. at 724; Letter from Maj. Gen. John Pope to Gen.-in-Chief Henry Halleck (Oct. 13, 1862), reprinted in id. at 733.

69. Letter from Maj. Gen. John Pope to Brig. Gen. Henry Sibley (Oct. 2, 1862), in Letters Rec'd-Adj. Gen., NARG 94 (M619, roll 483).

70. Sibley, too, rejected any notion of settling the conflict by treaty. See Letter from Col. Henry Sibley to Adj. Gen. Oscar Malmros (Sept. 4, 1862), in Sibley Papers, roll 11, frame 683, MHS [microfilm]. Rumors were circulating that a treaty would be concluded, and both Sibley and Pope apparently responded with assurances that they had no such intention. Id.

71. Letter from Maj. Gen. John Pope to Brig. Gen. Henry Sibley (Oct. 6, 1862), in Letters Rec'd-Adj. Gen., NARG 94 (M619, roll 483). Pope repeated similar sentiments on October 10 when he wrote to Sibley that all who were guilty in any way in the outbreak should be hanged. Letter from Maj. Gen. John Pope to Brig. Gen. Henry Sibley (Oct. 10, 1862), in Letters Rec'd-Adj. Gen., NARG 94 (M619, roll 483). He went on to say:

We have now the means to make a final settlement with all these Indians. The opportunity may not occur again. . . . Let me again say to you that I regard the destruction of every thing that can sustain life between Fort Ridgely and Big Stone Lake as very important.... 
Sibley expected another group of Dakota-those who had fied north with Taoyateduta but later abandoned him-to surrender shortly, and he decided not to order any executions of the convicted until after the surrender so as not to deter the others from returning. ${ }^{72}$ If the "other Indians" surrendered, he planned to take the men prisoner and march them to Fort Ridgely to be tried by the Commission. ${ }^{73}$ While Sibley still talked of separating the guilty from the innocent, he indicated that he thought most of the men were "deeply implicated in the late outrages" and warned those returning that if any more of the young men went off to war against the whites he would "fall upon their camp and cut them to pieces, without regard to age or sex."74 When several hundred more Dakota surrendered, Sibley informed Pope that he expected to imprison all the men except the very old and that the Dakota would "receive but small mercy" at his hands. Indeed, although he had not yet reviewed the proceedings of the Commission, which had by October 7 already condemned twenty Dakota to death, Sibley informed Pope that he probably would approve the results and "hang the villains" although the proceedings might not be "exactly in form."75

Between October 7 and 10, Pope wrote several times to General Halleck informing him that trials were in progress and that many of the Dakota who participated in the "late horrible outrages" would be executed. ${ }^{76}$ On October 13, Pope expressed his first doubt that he and Sibley were proceeding correctly, asking Halleck if they needed any further authority to execute those condemned by the Commission. 77

In accordance with earlier instructions received from Pope, Sibley had

All annuity Indians must be notified that hereafter they will not be permitted on any pretext to leave their reservation, that all the soldiers have orders to shoot them wherever they are found, and citizens are authorized to do the same.

Letter from Maj. Gen. John Pope to Brig. Gen. Henry Sibley (Oct. 10, 1862), supra.

72. Letter from Col. Henry Sibley to Maj. Gen. John Pope (Oct. 3, 1862), reprinted in 13 WAR of THE Rebellion, SER. I, supra note 52, at 708; see also Letter from Brig. Gen. Henry Sibley to Mrs. Henry Sibley (Oct. 5, 1862), in Sibley Papers, roll 11, frame 672, MHS [microfilm].

73. Letter from Col. Henry Sibley to Maj. Gen. John Pope (Oct. 4, 1862), reprinted in 13 WAR OF THE REBELLION, SER. I, supra note 52, at 710.

74. Letter from Col. Henry Sibley to Maj. Gen. John Pope (Oct. 5, 1862), reprinted in 13 WAR OF THE REBELlion, SER. I, supra note 52, at 711-12; see also Letter from Brig. Gen. Henry Sibley to Mrs. Henry Sibley (Oct. 10, 1862), in Sibley Papers, roll 11, frames 672-73, MHS [microfilm].

75. Letter from Col. Henry Sibley to Maj. Gen. John Pope (Oct. 7, 1862), reprinted in 13 WAR OF THE REBELLION, SER. I, supra note 52, at 717.

76. Letter from Maj. Gen. John Pope to Gen.-in-Chief Henry Halleck (Oct. 7, 1862), reprinted in 13 WAR OF THE REBELLION, SER. I, supra note 52, at 716; Letter from Maj. Gen. John Pope to Gen.-in-Chief Henry Halleck (Oct. 9, 1862), reprinted in id. at 722; Letter from Maj. Gen. John Pope to Gen.-in-Chief Henry Halleck (Oct. 10, 1862), reprinted in id. at 724.

77. Letter from Maj. Gen. John Pope to Gen.-in-Chief Henry Halleck (Oct. 13, 1862), reprinted in 13 WAR OF THE REBELLION, SER. I, supra note 52, at 733. In fact, a federal statute required the President's approval. Article of War 65 provided that, in time of peace, sentences involving loss of life could not be executed until laid before the President for his approval. Act of Apr. 10,1806 , ch. 20, $\S 1$, art. 65, 2 Stat. 359, 367. By Act of Dec. 24, 1861, Congress provided that, in time of war, approval was necessary only from the general commanding the army in the field or colonel commanding a separate department. Ch. 3, 12 Stat. 330. In July 1862, however, Congress specified that no sentence of death should be carried out until approved by the president. Act of July 17, 1862, ch. 201, § 5, 12 Stat. 597, 598. 
planned to send the convicted Dakota and the other disarmed men to Fort Snelling and to continue the trials there. On October 15, Sibley received new orders from Pope, instructing him to proceed with the trials, to execute those found guilty, and to send only the remainder to Fort Snelling. ${ }^{78}$

Meanwhile, on October 14, General Pope's report on the trials and planned executions was read at President Lincoln's cabinet meeting in Washington. Lincoln and his cabinet, apparently disturbed by the report and the planned executions, moved to prevent any precipitous action. ${ }^{79}$ On October 17, Pope wrote to Sibley that "[t]he President directs that no executions be made without his sanction." 80 By the time Sibley received that dispatch on October 21, he had reported to Pope that the Commission had tried more than 120 cases, with nearly 300 remaining. ${ }^{81}$

By November 3, the last day of trials, the Commission had tried 392 Dakota, with as many as 42 tried in a single day. ${ }^{82}$ Most were charged with murder, and a few were also charged with robbery or rape. ${ }^{83}$ Below each charge, the transcript listed "specifications." These specifications sometimes detailed particular murders, robberies, or rapes in which the prisoner was alleged to have been involved. But almost uniformly the specifications included the statement (or a close variation) that the prisoner "did, between the 19th of August and the 28th day of September, join and participate in various murders and outrages committed by the Sioux Indians on the Minnesota Frontier." 84 Often, the general statement of participation in the fighting was the only specification to the charge.

78. See Letter from Brig. Gen. Henry Sibley to Maj. Gen. John Pope (Oct. 15, 1862), reprinted in 13 WAR OF THE REBellioN, SER. I, supra note 52, at 740-41 (confirming that Sibley received Pope's two communications which modified his previous instructions).

79. D. Nichols, supra note 15, at 95-96.

80. Letter from Maj. Gen. John Pope to Brig. Gen. Henry Sibley (Oct. 17, 1862), in Letters Rec'd-Adj. Gen., NARG 94 (M619, roll 483).

81. Letter from Brig. Gen. Henry Sibley to Maj. Gen. John Pope (Oct. 21, 1862), reprinted in 13 WAR OF THE REBELLION, SER. I, supra note 52, at 756, 757.

82. Trial Transcripts, Case Nos. 275-316 (42 defendants tried on Nov. 1, 1862).

83. The description of the trials, unless otherwise noted, is drawn from the written transcripts made at the time of the trials. Isaac Heard, as Recorder, probably made most of the record. The transcripts are handwritten notes of the charges, evidence, and decisions. The arraignment page of the transcript in each case includes a list of the Commission members, case number, charges and specifications, the defendant's name, and the trial date. In many transcripts, that page appears to have been prepared in advance-identical in each case, with blank spaces for name and date to be added at the trial. See, e.g., Trial Transcripts, Case No. 13 (trial of O-Ton-Ka; the space for defendant's name is followed by the phrase, "a Sioux Indian," which was crossed out since O-Ton-Ka was a Winnebago), Case No. 6 (trial of Hin-han-shoon-ko-yag-ma-ne; name was shorter than blank space, so a long dash was placed to take up excess space); see also Trial Transcripts, Case Nos. 14, 22, 27 (the name Te-he-hdo-ne-cha is crossed out in each and the correct defendant's name (Sna-mani, Do-wan-sa, and Tu-wan-u-tak respectively) is written in. Te-hdo-ne-cha was the defendant in Case No. 2.). Trial dates were treated similarly. See note 65 supra. The transcripts contain more than one handwriting, so probably not all notes were taken by the same individual. The transcript appears to be a largely verbatim record, though one must expect that there are gaps because of the manner of recording. However, since the Commission received much of the testimony, from both prisoners and prosecution witnesses, through a translator, the testimony would have been given relatively slowly. It is therefore likely that the record is more complete than one might otherwise expect with hand transcription.

84. See Trial Transcripts. 
In each case, the members of the Commission were duly sworn, and the written charges were then read to the prisoner through an interpreter. The Commission gave the defendant an opportunity to speak and, if necessary, called witnesses against him. ${ }^{85}$ Some of the testimony against the prisoners was given by white women who had witnessed particular attacks or who had been held captive and had observed the men leaving and returning to camp, apparently after engaging in fighting. Most of the evidence that convicted the defendants, however, was provided either by the defendants themselves or by mixed-bloods who had been swept up in the war effort and who claimed that they had been forced to participate in the fighting. ${ }^{86}$

All defendants found to have participated in any fighting, whether against soldiers or against settlers, whether in a pitched battle or in a raid, were convicted and sentenced to be hanged. Those found to have participated only in plundering were found guilty and sentenced to terms of imprisonment ranging from one to ten years. Of the 392 men tried, the Commission convicted 323. Of those convicted, the Commission sentenced 303 to be hanged; only 20 were sentenced to terms of imprisonment. The Commission acquitted the remaining 69 prisoners. Eight of these were released during the early days of trial, but the rest remained imprisoned with the other men at the ironically named Camp Release. ${ }^{87}$

85. Apparently the Commission formed a pool of witnesses from which it could draw when evidence was needed. For example, Wakenyawashtay was listed as a witness in 92 trials, but testified in only 32 of them; Thomas Robertson was listed as a vitness in 66 trials, but testified in only 33 of them; Alex Graham was listed as a witness in 61 trials, but testified in only 16 of them. See Trial Transcripts. On several occasions the Commission called witnesses from the pool whose only testimony was that they knew nothing about the defendant's participation or actions. See, eg., Trial Transcripts, Case No. 49 (both David Faribault and Alex Graham knew nothing of defendant's actions); Case No. 55 (Thomas Robertson had no information about the defendant); Case No. 76 (Alex Graham and David Faribault did not know anything about the defendant's actions).

86. See text accompanying notes $224-246$ infra.

87. A week after the conclusion of the trials of the Dakota, the Military Commission tried about a dozen Winnebagos who had participated in the fighting along with the Dakota. The Mankato Record reported that a Winnebago, Hoonkhoonokaw (Little Chief or Little Priest) was found to have been present "at the massacre at the Upper Agency" and to have stabbed Andrew Myrick after Myrick was shot. Mankato Rec., Nov. 15, 1862, at 2, col. 1. The newspaper also noted that a Dakota witness proved that Maznopinki was present at the battle at Wood Lake, riding on the same horse as the witness. Id. Another witness against the Winnebagos may have been Otanka, a Winnebago who had married a Dakota woman and was living with his family at the time of the War. The Commission tried and acquitted him on October 4 and held him as a vitness after he testified that he had heard that nine Winnebagos were at the battle of the Redwood Agency. See Trial Transcripts, Case No. 13.

Despite this evidence, which would have been sufficient to convict Dakota defendants, the Commission acquitted all or all but one of the Winnebagos, and there is no indication that any Winnebagos were imprisoned or executed. THOMAS HUGHES, INDIAN CHIEFS OF SOUTHERN MiNNESOTA 152-53, 181 (1969). I was unable to find transcripts of the Winnebago trials to compare the results with the verdicts against the Dakata. The Mankato Record reported that "[a]n unusual effort was made by Indian officials and sympathisers to save [the Winnebago] necks," Mankato Rec., supra, suggesting one possible reason for the seemingly different treatment.

There were also reports that the Commission tried one Dakota woman, but acquitted her. Letter from Rev. Stephen R. Riggs to Martha Riggs (Nov. 4, 1862), in Riggs Papers, MHS. 


\section{Presidential Review of the Trials}

Prevailing federal statutes required the President's approval before the sentences of death could be carried out, ${ }^{88}$ although Sibley and his immediate superiors had initially been unaware of that requirement. ${ }^{89}$ By November 10, Major General Pope had forwarded to Lincoln the names of the condemned men; Lincoln responded by requesting "the full and complete record of their convictions" and "a careful statement" indicating "the more guilty and influential of the culprits." 90 Pope forwarded the transcripts on November 15 , preceded by a letter in which he urged the President to execute all of the condemned, claiming that "the only distinction between the culprits is as to which of them murdered most people or violated most young girls." $1 \mathrm{He}$ warned that the people of Minnesota, perhaps combined with some of the soldiers, would take matters into their own hands and kill "all the Indiansold men, women, and children," if the President did not allow all the executions to go forward. ${ }^{92}$ If the President proved reluctant to decide, he suggested, the condemned could be turned over to the state government.93 Minnesota Governor Ramsey left no doubt what decision he would make if given the opportunity, writing to Lincoln to urge execution of all the condemned.94

A great public outcry arose in Minnesota in response to reports that Lincoln might not carry out the full sentence of the military commission. ${ }^{95}$ The Stillwater, Minnesota Messenger demanded extermination of the Dakota: "DEATH TO THE BARBARIANS! is the sentiment of our people."96 Minnesota's Senator Morton Wilkinson and Representatives Cyrus Aldrich and William Windom wrote to Lincoln reciting stories of rapes and mutilation "well known to our people" and protesting any decision to pardon or reprieve the Dakota. ${ }^{97}$ If the President did not permit the executions, they said, "the outraged people of Minnesota would dispose of these wretches without law. These two peoples cannot live together. We do not wish to see mob law inaugurated in Minnesota, as it certainly will be, if you force the

88. See Act of July 17, 1862, ch. 201, $\S 5,12$ Stat. 597, 598; note 77 supra.

89. See texts accompanying notes $57-59$, \& 77 supra.

90. Letter from Pres. Abraham Lincoln to Maj. Gen. John Pope (Nov. 10, 1862), reprinted in 13 WAR OF THE REBELLION, SER. I, supra note 52, at 787.

91. Letter from Maj. Gen. John Pope to Pres. Abraham Lincoln (Nov. 11, 1862), reprinted in 13 WAR OF THE REBELLION, SER. I, supra note 52, at 788.

92. Id.

93. Letter from Maj. Gen. John Pope to Pres. Abraham Lincoln (Nov. 12, 1862), in Abraham Lincoln Papers, Minnesota Historical Society, quoted in D. NICHOLS, supra note 15, at 101.

94. Letter from Gov. Alexander Ramsey to Pres. Abraham Lincoln (Nov. 10, 1862), reprinted in 13 WAR OF THE REBELLION, SER. I, supra note 52, at 787 . In a proclamation to the people of Minnesota, Ramsey had already promised revenge on the Dakota and threatened to convict them in state court if Lincoln did not allow the executions. St. Paul Pioneer, Dec. 7, 1862, at 1, col. 3.

95. See D. Nichols, supra note 15 , at 101-11.

96. Stillwater Messenger, Nov. 11, 1862, at 1, col. 1.

97. Letter from Sen. Morton Wilkinson, Rep. Cyrus Aldrich, and Rep. William Windom to Pres. Abraham Lincoln (Nov. 1862), reprinted in S. ExEc. Doc. No. 7, 37th Cong., 3d Sess. 2, 3 (1862). 
people to it."98 An open letter to the President from "the citizens of St. Paul" called the actions of the Dakota "wanton, unprovoked and fiendish cruelty," predicting further violence by "these Indians" if an example were not made by executing the convicted, and predicting vengeance by the settlers if the government did not act.99

Others expressed doubt about the proper response. Commissioner of Indian Affairs William P. Dole, visiting in Minnesota, suggested that execution of the sentence would partake "more of the character of revenge than of punishment."100 Reverend Riggs and Bishop Henry Whipple urged clemency for men involved in battles or plundering rather than in murdering women and children. ${ }^{101}$ Some in the East, more removed from the scene, expressed sympathy for the imprisoned Dakota. ${ }^{102}$

Lincoln was apparently torn between the cries for vengeance and his concerns about potential injustice to the accused. ${ }^{103}$ On December 1, he wrote to Judge Advocate General Joseph Holt, asking his legal opinion whether "if I should conclude to execute only a part of them, I must myself designate which, or could I leave the designation to some officer on the ground?'104 Holt replied that the decision to pardon could not be delegated.105 On December 5, hoping to force the President's hand and prevent sympathetic appeals from "shak[ing] his purposes," Minnesota Senator Wilkinson introduced a resolution requesting that the President give an account to the Senate of the events in Minnesota and the evidence upon which the Commission ordered execution. ${ }^{106}$

Meanwhile, Colonel Stephen Miller, commanding officer of the regiment holding the condemned prisoners, repeatedly reported unrest among the citizens and soldiers, which he feared would lead to mob violence against the Dakota. Indeed, as the wagon train of prisoners moved through $\mathbb{N e w} \mathrm{Ulm}$ on its way from Camp Release to Mankato, a crowd of men, women, and children pelted the shackled Dakota with bricks and other missiles, seriously injuring some prisoners and guards. ${ }^{107} \mathrm{~A}$ mob attacked the rest of the $\mathrm{Da}-$

98. Id. at 4 .

99. Id. at 4-6.

100. Report of the Comm'r of Indian Affairs, William Dole, to Sec'y of the Interior Caleb Smith (Nov. 26, 1862), reprinted in H.R. ExEc. Doc. No. 1, 37th Cong., 3d Sess. 169, 177 (1862).

101. D. Nichols, supra note 15, at 103-04.

102. See CONG. GIOBE, 37th Cong., 3d Sess. 13 (1862) (remarks of Sen. Wilkinson). In his memoir of the life of Sibley, J. Fletcher Williams later charged that President Lincoln prevented execution of the condemned "at the earnest solicitation of some pseudo humanitarians at the East." J. Fletcher Williams, Henry Hastings Sibley: A Memoir, in 6 Collections OF THE MINNESOTA HISTORICAL SOCIETY 257, 291 (1894).

103. D. Nichols, supra note 15 , at $99-100$.

104. Letter from Pres. Abraham Lincoln to J. Adv. Gen. Joseph Holt (Dec. 1, 1862), reprinted in 5 Collected Works of ABRAHAM LINCOLN 537-38 (R. Basler ed. 1954).

105. Letter from J. Adv. Gen. Joseph Holt to Pres. Abraham Lincoln (Dec. 1, 1862), in Letters Sent-JAG, NARG 153 (Entry 1).

106. CoNG. GloBE, 37th Cong., 3d Sess. 13 (1862).

107. Letter from Brig. Gen. Henry Sibley to Mrs. Henry Sibley (Nov. 12, 1862), in Sibley Papers, roll 11, frame 679, MHS [microfilm]. The crowd was driven back by a bayonet charge, and some 15 men were arrested, marched with the wagon train to camp, reprimanded, and released. Id. Two of the prisoners reportedly died as a result of the attack, "the guard refusing or neglecting to 
kota-the "friendly" community-on their way to Fort Snelling; one baby was snatched from its mother's arms and beaten to death. ${ }^{108}$

After being moved from Camp Release, the prisoners were held in an open field near Mankato, where they were easy objects of attack. On November 16, Miller reported the existence of an "extensive secret organization including men of character in all this upper country, and many soldiers" who would attempt to take charge of the prisoners unless they were executed within a week. "I was informed only yesterday," Miller said, "that the Sheriff was very busy exciting the citizens upon this subject."109 On the 22nd, 23rd, and 26th, Miller warned again of possible mob violence, particularly if word spread that the prisoners were to be moved from Mankato or pardoned. "[ $[\mathrm{t} t$ is daily hinted to me," he went on, "that too many of the Soldiers participate in this feeling and determination."110 Miller was making plans to build a log prison to hold the men more securely and thought that he could "get the prisoners safely into town, but to get them out would require a small army."111

At 11 P.M. on December 4, several hundred civilians, armed with clubs, hatchets, and knives, attacked the new camp. Miller reported that the mob had planned to meet with 2000 other people the next day and intended to murder the prisoners. ${ }^{112}$ The soldiers surrounded, arrested, and disarmed the civilians, then permitted them to return to Mankato after receiving promises of good behavior. The soldiers had acted rapidly to put down the attack, with good results, ${ }^{113}$ but Miller continued to warn of a "general, fearful and bloody demonstration" if the prisoners were moved or if a gen-

keep the mob off." Letter from Rev. Thomas Williamson to S.B. Treat (Dec. 1, 1862), in ABCFM Papers, MHS.

108. Daniel Buck, Indian Outbreaks 222-23 (1904) (published 1965).

109. Letter from Col. Stephen Miller to Brig. Gen. Henry Sibley (Nov. 16, 1862), in Letters Rec'd, NARG 393 (Entry 346).

110. Letter from Col. Stephen Miller to Brig. Gen. Henry Sibley (Nov. 22, 1862), in Letters Rec'd, NARG 393 (Entry 346); Letter from Col. Stephen Miller to Brig. Gen. Henry Sibley (Nov. 23,1862 ), in id.

111. Letter from Col. Stephen Miller to Ass't Adj. Gen. Rollin Olin (Nov. 26, 1862), in Letters Rec'd, NARG 393 (Entry 346).

112. Letter from Col. Stephen Miller to Ass't Adj. Gen. Rollin Olin (Dec. 5, 1862), in Letters Rec'd, NARG 393 (Entry 346).

113. Second letter from Col. Stephen Miller to Ass't Adj. Gen. Rollin Olin (Dec. 5, 1862), in Letters Rec'd, NARG 393 (Entry 346). Miller issued a proclamation commending the soldiers who helped to defeat the attackers. The proclamation acknowledged the soldiers' own desire for "the prompt and universal execution of the guilty savages," but cautioned agitators that the soldiers would do their duty "so long as the avenues of government point to the final and certain vindication of right and justice." Gen. Order No. 6 (Dec. 6, 1862), enclosed in Letter from Col. Stephen Miller to Ass't Adj. Gen. Rollin Olin (Dec. 6, 1862), in Letters Rec'd, NARG 393 (Entry 346). Not all soldiers were so dutiful. There were several reports that members of the state militia were instrumental in urging the attack on the camp and that some had participated in it in civilian clothing, possibly using arms belonging to the state. See Letter from 1st Lt. E. Kennedy to Col. Stephen Miller, enclosed in Letter from Col. Stephen Miller to Ass't Adj. Gen. Rollin Olin (Dec. 9, 1862), in Letters Rec'd, NARG 393 (Entry 346); Letter from Col. Stephen Miller to Ass't Adj. Gen. Rollin Olin (Dec. 11, 1862), in id. Major Brant, of the militia, was reported to be one of the ringleaders; the night before the attack he had been heard to say, "Tonight I hold in my left hand a glass of lager Beer but tomorrow night will hold in my right hand an Indian scalp." Letter from 1st Lt. E. Kennedy to Col. Stephen Miller, supra. 
eral pardon were issued. ${ }^{114}$

In response to the attack on the camp, Governor Ramsey issued a proclamation urging the people of Minnesota to act with restraint and to obey the law. The proclamation was a double-edged sword, however; it suggested that Lincoln ultimately would agree to execute the prisoners and warned that the state courts and legislature would take action if the federal government did not. ${ }^{115}$

On December 6, Lincoln finally issued his decision. In his message to the Senate, he explained that he had been "[a]nxious to not act with so much clemency as to encourage another outbreak, on the one hand, nor with so much severity as to be real cruelty, on the other."116 He had, accordingly, ordered a review of the transcripts with the intention of ordering the execution of only those who had been "proved guilty of violating females."117 Lincoln indicated that, contrary to his expectations, only two men had been convicted of rape, so he determined to draw the line by executing those who had participated in "massacres," as distinguished from those who had participated in "battles."118 Of the forty men fitting this description, he said, one had been recommended by the Commission for clemency, ${ }^{119}$ leaving

114. Letter from Col. Stephen Miller to Ass't Adj. Gen. Rollin Olin (Dec. 9, 1862), in Letters Rec'd, NARG 393 (Entry 346); see also Letter from Col. Stephen Miller to Ass't Adj. Gen. Rollin Olin (Dec. 7, 1862), in id. (stating that although prominent citizens promised support, they thought that "an attempt to remove the Indians below would be a proper excuse for respectable citizens to interfere"); Letter from Col. J. Baker to Brig. Gen. Henry Sibley (Dec. 7, 1862), in id. (reporting "a concerted movement for the forcible seizure of those prisoners" and a paper signed by 400 who pledged to murder the prisoners if the President refused to order their execution); Telegram from Brig. Gen. Henry Sibley to Brig. Gen. Elliott (Dec. 8, 1862), in Letters and Telegrams Sent, NARG 393 (Entry 343) (requesting that the President, should he decide to pardon the condemned, keep the decision secret so the military could prepare for the expected onslaught).

115. Proclamation of Gov. Alexander Ramsey (Dec. 6, 1862), in Lincoln Papers, roll 45, Library of Congress [microfilm], quoted in D. Nichols, supra note 15, at 111.

116. S. ExEc. Doc. No. 7, 37th Cong., 3d Sess. 1 (1862).

117. Id. at 1-2.

118. Id. The distinction between "massacres" and "battles" was suggested to Lincoln earlier in communications from Reverend Riggs and Bishop Whipple. Riggs agreed that the execution of "the great majority" of the condemned was necessary but suggested distinguishing "grades of guilt from the man who butchered women and children to the man who simply followed with a party for the purpose of taking away spoils from the homes of settlers who had fled." Letter from Rev. Stephen Riggs to Pres. Abraham Lincoln (Nov. 17, 1862), in Lincoln Papers, roll 44, Library of Congress [microfilm], quoted in D. Nichols, supra note 15, at 103. Whipple offered a similar opinion:

[T]here is a broad distinction be[t]ween the guilt of men who went through the country committing fiendish violence, massacreing [sic] women \& babes with the spirit of demons $\&$ the guilt of timid men who received a share of the plunder or who under threat of death engaged in some one battle where hundreds were engaged.

Letter from Bishop Henry Whipple to the Editor of the Republican Pioneer (undated, probably Nov. 1862), in Whipple Papers, MHS.

119. S. EXEc. Doc. No. 7, supra note 116, at 2. The prisoner recommended for clemency was Godfrey, also called Otakle, the first of the defendants to be tried. He was the "mulatto" mentioned in Sibley's order organizing the Commission. He had lived near the Redwood (Lower) Agency for five years and was married to a woman from Wabasha's band of Mdewakanton Dakota. I. HEARD, supra note 6 , at 189,191 . According to Heard, the members of the court were prejudiced against Godfrey at the outset but were impressed by his presentation and inclined to believe his testimony might be accurate. Id. at 254 . Ultimately the court found him not guilty of the original charges of murdering seven white men, women, and children, but convicted him of participating in the fighting and sentenced him to be hanged. The court's "sympathy" was reflected in a recommendation that 
thirty-nine to be executed on December 19. He ordered that the remaining prisoners be held "subject to further orders, taking care that they neither escape, nor are subjected to any unlawful violence."120

\section{The Executions}

Officials in Minnesota worried that a violent reaction would follow the President's decision to execute only thirty-nine prisoners. Sibley immediately requested that Lincoln postpone the execution for one week, ${ }^{121}$ writing to Miller that he needed "time for due preparation and for the concentration of the troops necessary to protect the other Indians and ... to prevent a fearful collision between the U.S. forces and the citizens." 122

As of December 17, the prisoners had apparently not been told of the President's decision. On that date, Reverend Augustin Ravoux wrote to Sibley requesting that he separate the condemned men from the others and inform them of their fate at least one day before the planned execution to let them prepare themselves "for the awful judgement of God."123 The condemned men were finally moved on December 22. Later reports suggest that, because of the similarity of several of the Dakota names, some errors were made in identifying the thirty-nine condemned individuals from the larger group of those convicted, ${ }^{124}$ but Sibley denied this claim. ${ }^{125}$

the sentence be commuted to 10 years imprisonment because he had testified against many other prisoners. See Trial Transcripts, Case No. 1 (memorandum by the Commission to Brig. Gen. Henry Sibley, Nov. 5, 1862); text accompanying notes 224-229 infra.

120. Letter from Pres. Abraham Lincoln to Brig. Gen. Henry Sibley (Dec. 6, 1862), reprinted in 5 COLLECTED WORKS OF ABRAHAM LINCOLN, supra note 104, at 542-43.

Sibley believed that the President would probably order further executions. In a letter to Miller, Sibley suggested that the order to retain the remaining prisoners should satisfy the people that the President did not intend to release any of them. "It is probable there will be an order issued for further executions," he wrote, "but of course that is but conjectural." Letter from Brig. Gen. Henry Sibley to Col. Stephen Miller (Dec. 15, 1862), in Letters and Telegrams Sent, NARG 393 (Entry 343). Sibley received some support for this notion from Assistant Secretary of the Interior John Usher, who wrote to Sibley on December 10 that "I do not understand from [the President] that he has determined not to approve of the finding of the Court in more of the cases, but he finds some difficulty in doing so, because of the meagre manner in which the evidence has been reported to him." Letter from Ass't Sec'y of the Interior John Usher to Brig. Gen. Henry Sibley (Dec. 10, 1862), in Letters Rec'd, NARG 393 (Entry 346). Olin expressed a similar sentiment in a letter to Miller three days later:

[B]e particular to represent the sentiments of the President so far as can be judged of his

order, which is specific as to the safe custody, intimating thereby, that the punishment of the thirty-nine may be followed by a like disposition of all or a portion of the remainder, or

the infliction of such other penalty as he deem it necessary to prescribe.

Letter from Ass't Adj. Gen. Rollin Olin to Col. Stephen Miller (Dec. 18, 1862), in Letters and Telegrams Sent, NARG 393 (Entry 343).

121. Telegram from Brig. Gen. Henry Sibley to Pres. Abraham Lincoln (Dec. 15, 1862), in Letters and Telegrams Sent, NARG 393 (Entry 343).

122. Letter from Brig. Gen. Henry Sibley to Col. Stephen Miller (Dec. 15, 1862), in Letters and Telegrams Sent, NARG 393 (Entry 343).

123. Letter from Rev. Augustin Ravoux to Brig. Gen. Henry Sibley (Dec. 17, 1862), in Letters Rec'd-Adj. Gen., NARG 94 (M619, roll 483); see also Bruce David Forbes, Evangelization and Acculturation Among the Santee Dakota Indians, 1834-1864, at 292 (1977) (unpublished doctoral dissertation, Princeton Theological Seminary).

124. R. MEYER, supra note 6, at 130; M. SATTERLEE, supra note 6, at 17. One such error may have been the hanging of Chaska, who had done much to save the life of Sarah Wakefield, one of the 
After the division was made, Reverend Riggs addressed the condemned prisoners, translating to them the President's order and a statement apparently prepared by Miller:

Their Great Father at Washington, after carefully reading what the witnesses testified to in their several trials, has come to the conclusion that they have each been guilty of wantonly and wickedly murdering his white children. And for this reason he has directed that they each be hanged by the neck until they are dead, on next Friday; and that order will be carried into effect on that day, at ten o'clock in the forenoon:

That good ministers are here, both Catholic and Protestant, from amongst whom each one can select a spiritual adviser, who will be permitted to commune with them constantly during the few days that they are yet to live:

-...

Say to them now that they have so sinned against their fellow men, that there is no hope for clemency except in the mercy of God, through the merits of the blessed Redeemer and that I earnestly exhort them to apply to that, as their only remaining source of comfort and consolation. ${ }^{126}$

The prisoners received the news of their impending execution with equanimity, according to Dakota tradition:

Several Indians smoked their pipes composedly during the reading, and we observed one in particular who, when the time of execution was designated, quietly knocked the ashes from his pipe and filled it afresh with his favorite kinnekinnick; while another was slowly rubbing a pipefull of the same article in his hand, preparatory to a good smoke. ${ }^{127}$

On December 23, the President suspended the execution of one of the condemned men, Tatimima, after Sibley telegraphed that new information led him to doubt the prisoner's guilt.128 Preparations proceeded to hang the remaining thirty-eight. The settlers in the region took great interest in the hanging, and Colonel Miller feared violence from many of those arriving, uninvited, to view the execution. To help keep the peace, Miller declared martial law would be in effect from the morning of December 25 , the day

white captives. The military officials claimed he was mistakenly hanged instead of Chaskadon (number 121), who was convicted of killing a pregnant woman. Wakefield believed that no mistake had been made: Chaska's protection of her led to stories that she had become his wife during the captivity, and she believed he was hanged to punish him for engaging in such a relationship with a white woman. Nick Coleman \& John Camp, The Great Dakota Conflict, Part III, St. Paul Pioneer Press Dispatch, Oct. 11, 1987, at 5G, col. 3 (citing SARAH F. WAkefield, Sxx Wreks IN THE SIOUX TEEPEES (1864)). Thomas Robertson reported that one 18-year-old without full mental faculties was mistakenly hanged instead of another man with the same name. Reminiscences of Thomas $A$. Robertson 32, in Sioux Uprising Collection, MHS.

125. Letter from Brig. Gen. Henry Sibley to Bishop Henry Whipple (Mar. 11, 1863), in Whipple Papers, MHS.

126. Letter from Col. Stephen Miller to Ass't Adj. Gen. Rollin Olin (Dec. 22, 1862), in Letters Rec'd-Adj. Gen., NARG 94 (M619, roll 483); St. Paul Daily Press, Dec. 28, 1862, at 1, cols. 3-4.

127. St. Paul Daily Press, Dec. 28, 1862, at 1, col. 4.

128. Telegram from Brig. Gen. Henry Sibley to Pres. Abraham Lincoln (Dec. 22, 1862), in Letters and Telegrams Sent, NARG 393 (Entry 343); Letter from Brig. Gen. Henry Sibley to Col. Stephen Miller (Dec. 23, 1862), in Letters and Telegrams Sent, NARG 393 (Entry 343). 
before the scheduled execution. 129 Meanwhile, the troops constructed a scaffold large enough to hang all thirty-eight at one time.

Having apparently accepted their fate, the condemned prepared themselves for the execution. On the evening of December 23, the prisoners danced and sang together, probably to demonstrate their calmness and to honor each other and their relatives. ${ }^{130}$ On the 24 th, they were permitted to meet with male relatives and friends also confined at the camp in order to say goodbye and send messages and words of comfort to their families. These meetings were reported to be "sad and affecting," with many of the prisoners moved to tears. ${ }^{131}$ Tatimima, not yet informed that his execution had been stayed, sent word to his relatives not to mourn him, that he died innocent of any white man's blood, and hoped his friends would thus consider his death as simply a removal to a better world. ${ }^{132}$ Reflecting a belief that more of the prisoners would later be executed, Tazoo said:

[T] ell our friends that we are being removed from this world over the same path they must shortly travel. We go first, but many of our friends may follow us in a very short time. I expect to go direct to the abode of the Great Spirit, and to be happy when I get there; but we are told that the road is long and the distance great; therefore, as I am slow in all my movements, it will probably take me a long time to reach the end of the journey, and I should not be surprised if some of the young, active men we will leave behind us will pass me on the road before I reach the place of my destination. ${ }^{133}$

On the 25th, Christmas Day, the condemned met with female relatives who had been working as cooks for the prisoners. These interviews were reported to be less sad. The prisoners sent messages to their relatives and friends, advising them to "bear themselves with fortitude and refrain from great mourning"; they also distributed personal items and locks of hair for the women to give to those outside. ${ }^{134}$

Shortly before the time for execution, Hdainyanka (Rattling Runner) ${ }^{135}$ dictated a letter to Wabasha, his father-in-law, one of the leaders who had counseled against the fighting and had helped negotiate the surrender to Sibley:

WABASHA $],-Y o u$ have deceived me. You told me that if we followed the advice of General Sibley, and gave ourselves up to the whites, all would be well; no innocent man would be injured. I have not killed, wounded, or

129. Gen. Order No. 21, Dec. 24, 1862, reprinted in I. HeARD, supra note 6, at 277.

130. Apparently the authorities feared the celebration was the prelude to an escape attempt and thereafter fastened the prisoners' chains to the floor. I. HEARD, supra note 6, at 284. A reporter present thought the condemned were probably singing death songs. Id. (quoting "written account" of Mr. Riggs).

131. Id. at $284,286$.

132. Id. at 285 .

133. Id. at 285-86.

134. Id. at 286-87.

135. "Rdainyanka" is the spelling usually appearing in written accounts, but "Hdainyanka" is a more correct spelling. Interview with Dr. Chris Cavender, Coordinator of the Dakota Studies Committee, in Minneapolis, Minn. (Sept. 29, 1989). 
injured a white man, or any white persons. I have not participated in the plunder of their property; and yet to-day I am set apart for execution, and must die in a few days, while men who are guilty will remain in prison. My wife is your daughter, my children are your grandchildren. I leave them all in your care and under your protection. Do not let them suffer; and when my children are grown up, let them know that their father died because he followed the advice of his chief, and without having the blood of a white man to answer for to the Great Spirit.

My wife and children are dear to me. Let them not grieve for me. Let them remember that the brave should be prepared to meet death; and I will do as becomes a Dakota. ${ }^{136}$

Several of the Christian missionaries stayed with the condemned through that night. They reported that the prisoners were "cheerful and contented" and had asked the missionaries to tell their wives and children how "cheerful and happy they all had died, exhibiting no fear of this dread event."137

At 7:30 A.M. on December 26, the iron manacles were removed and cords were used to secure the prisoner's arms. The men continued their songs and conversation, and each shook hands with the soldiers and reporters present to wish them goodbye. ${ }^{138}$ Father Ravoux led them in prayer, after which white hoods, rolled up to reveal their face paint, were placed on the prisoners in preparation for the execution. The head coverings were a source of shame - the Dakota would have wanted to show that they faced death without flinching ${ }^{139}$ - and after being hooded, the men became more subdued. ${ }^{140}$ At exactly 10:00 A.M., soldiers led the men out of the prison and to the scaffold. The condemned maintained their composure to the end, walking "eagerly and cheerfully, even crowding and jostling each other to be ahead." 141 As they ascended the scaffold, watched by a throng of spectators, they began to sing loudly what was variously reported as a death song or a hymn. ${ }^{142}$ One of the men sang of his deeds in battle, mocking the crowd

136. I. HEARD, supra note 6, at 284. Hdainyanka's sense that he had been misled into surrendering was no doubt shared by Chief Wabasha III and the other chiefs. Before the cessation of fighting, Sibley had assured the chiefs that he sought to punish only those who had been involved in the "murder and outrages upon the white settlers," see text accompanying notes 51-52 supra, but the Commission tried and convicted many, like Hdainyanka, who had fought only in battles, see text accompanying notes 205-246 infra.

Despite his sense of betrayal, Hdainyanka committed his family to Chief Wabasha's protection. The family ties between Hdainyanka and Wabasha only partially explain this action. Chief Wabasha had traditionally provided for and taken under his protection widows, orphans, and others in his band who required such support. His father and grandfather before him played the same role. Interview with Ernest Wabasha, hereditary Chief Wabasha VII, Lower Sioux Mdewakanton Community, in Morton, Minn. (July 23, 1989).

137. I. HEARD, supra note 6 , at $287,288$.

138. Id. at 288-89.

139. See, e.g., VINE Deloria, JR., GOD is RED 177-81 (1973).

140. I. HEARD, supra note 6, at 289-90.

141. Id. at 290.

142. A St. Paul Press reporter viewing the execution stated that the men were singing a death song. I. HEARD, supra note 6 , at 284,290 . A death song is a special song sung by a person facing certain death. It acts "as a benedictory statement by the individual to summarize and conclude his time of existence." V. DELORIA, supra note 139, at 180. For the Dakota, "it was the final affirmation of the meaning of individual existence, for it glorified the personal integrity of the person. It individ- 


\section{with reference to a mutilated body at New Ulm. ${ }^{143}$}

Three drum beats signaled the moment of execution. Many of the men clasped the hands of their neighbors. As the rope was cut, and the bodies fell, a single prolonged cheer arose from the soldiers and citizens watching the spectacle. Then the soldiers cut down the bodies and the crowd dispersed. The crowd was orderly, probably due in large part to the preparations of Colonel Miller and the declaration of martial law. The bodies were buried in a single grave four feet deep on the edge of town. ${ }^{144}$

\section{E. The Survivors}

The Dakota convicted by the Commission but not executed continued to be held as prisoners, since no general pardon was issued. The rest of the Dakota community also remained under restraint, most of them in an internment camp at Fort Snelling. ${ }^{145}$ Beginning shortly after the trials concluded and extending well into 1863, Sibley and others continued to collect evidence to determine if they should bring any other Dakota to trial or have any more of the sentences carried out, ${ }^{146}$ but no further executions or trials

ualized his tribal membership in a manner bringing credit and meaning to his life as a tribal member." Id.

At least one oral tradition suggests the song was a Christian hymn sung in the Dakota language. Rev. Sidney Byrd, Comments at the Year of Reconciliation: Symposium Commemorating the United States-Dakota Conflict of 1862, Humphrey Institute of Public Affairs, Univ. of Minn. (Nov. 13-14, 1987).

143. I. HEARD, supra note 6, at 291. A song taunting the enemies who were about to kill the singer is one traditional form of death song. V. DELORIA, supra note 139, at 180 .

144. I. HEARD, supra note 6, at 291-95. On December 28, Miller reported that each night some of the bodies were being removed and left exposed, and that he daily reinterred them. Letter from Col. Stephen Miller to Ass't Adj. Gen. Rollin Olin (Dec. 28, 1862), in Letters Rec'd, NARG 393 (Entry 346). In reply, Sibley ordered that "every possible measure be taken to prevent the removal, or exposure" of the bodies. Letter from Ass't Adj. Gen. Rollin Olin to Col. Stephen Miller (Dec. 31, 1862), in Letters and Telegrams Sent, NARG 393 (Entry 343). Apparently these efforts were not entirely successful. Later reports indicate that many of the bodies had been exhumed by local doctors, who used them as cadavers for research. K. CARLEY, supra note 6, at 75; R. MEYER, supra note 6 , at 130 .

145. The winter had been hard on the prisoners at Mankato. Three of them died even before the executions. See Report of Major Joseph Brown (Dec. 31, 1862), in Letter from Col. Stephen Miller to Brig. Gen. Henry Sibley (Jan. 5, 1863), in Letters Rec'd, NARG 393 (Entry 343). At least six more died of consumption, pleurisy, and other ailments during the next six weeks. See Certification by Surgeon H. Seigneuret, in Indian Prisoners, NARG 94 (Entry 173). Meyer reports a total of 13 deaths. R. MEYER, supra note 6, at 136. Meanwhile, conditions were no better at Fort Snelling, where about 130 of 1,600 Dakota died. Id. at 136.

146. See Letter from Maj. Joseph Brown to Brig. Gen. Henry Sibley (Nov. 16, 1862), in Indian Prisoners, NARG 94 (Entry 173) (reporting new evidence from Mazasha (Red Iron) that Wateanna participated in the second battle of New Ulm and the battle at the Big Woods); Letter from Col. William Crooks to Brig. Gen. Henry Sibley (Dec. 27, 1862), in id. (reporting new evidence from Michael Renville that Waundan had killed Dickinson at the battle of Birch Coolie and from Kanvisapa that Pijivota had killed nine persons near Beaver Creek); Letter from Col. Stephen Miller to Ass't Adj. Gen. Rollin Olin (Dec. 30, 1862), in id. (reporting new evidence from Mr. Covell that Toonkontoecheyayda had murdered a white woman in his presence); "Charges Against We-yu-hama-ne" (Mar. 25, 1863), in id. (recorded statement of Hapan reporting that Weyuhamane had told her he killed four women and two children at Beaver Creek and that witnesses saw him kill another woman in her presence); see also D. Nichols, supra note 15, at 112 \& n.43 (in January and February 1863, Sibley sent more evidence to Lincoln and sought the execution of 50 more prisoners). 
occurred. In February 1863, John Nicolay, President Lincoln's Secretary, wrote to Sibley requesting his opinion about what to do with the remaining condemned men. ${ }^{147}$ Sibley apparently still hoped for further executions but suggested that the government send those not hanged to military prison in Illinois or in some other way remove them from Minnesota, where public sentiment still ran strongly against them. ${ }^{148}$ Finally, in late March, the decision was made to send the convicted men to Camp McClellan in Davenport, Iowa. ${ }^{149}$

Meanwhile, Congress had enacted a statute providing for the removal of all members of the four bands of Dakota from Minnesota, leaving the President to select an appropriate place for a new reservation. ${ }^{150}$ In April 1863, the men who had been acquitted and the fifteen or twenty women who had served at the prison in Mankato were reunited with the sixteen hundred Dakota still held at Fort Snelling. The convicted prisoners were transported to a new prison camp in Iowa, ${ }^{151}$ while the rest of the community was moved to a reservation at Crow Creek in South Dakota. ${ }^{152}$

147. Letter from John Nicolay to Brig. Gen. Henry Sibley (Feb. 7, 1863), in Letters Rec'd, NARG 393 (Entry 346).

148. Letter from Brig. Gen. Henry Sibley to Ass't Adj. Gen. R. Selfridge (Feb. 9, 1863), in Letters and Telegrams Sent, NARG 393 (Entry 343); Letter from Brig. Gen. Henry Sibley to Ass't Adj. Gen. R. Selfridge (Mar. 9, 1863), in id.; Letter from Brig. Gen. Henry Sibley to Ass't Sec'y of the Interior John Usher (Mar. 14, 1863), in id.

149. Letter from Ass't Adj. Gen. Rollin Olin to Col. Stephen Miller (Mar. 25, 1863), in Letters and Telegrams Sent, NARG 393 (Entry 343); Letter from Ass't Adj. Gen. Rollin Olin to Col. Stephen Miller (Apr. 12, 1863), in id. Sibley was apparently concerned that the prisoners would attempt to escape when they were moved. He cautioned those transperting the Indians to "exercise the most rigid surveillance over the Indians by day as well as by night. The manacles of the Indians should be examined three or four times during the day, and as often during the night. They must never be left in the dark for a single moment." Letter from Brig. Gen. Henry Sibley to Capt. William Burt (Apr. 11,1863 ), in $i d$. The military was also concerned, once again, about violence from local mobs, so the plans to move the prisoners were kept secret until the last possible moment. R. MEYER, supra note 6, at 143.

150. An Act for the Removal of the Sisseton, Wahpaton, Medawakanton, and Wahpakoota [Wahpekute] Bands of Sioux or Dakota Indians, and for the Disposition of their Lands in Minnesota and Dakota, 12 Stat. 819 (1863). As Meyer notes, this was the first time the United States had chosen to remove Indians unilaterally by statute, without even the semblance of agreement by treaty. R. MEYER, supra note 6, at 141.

151. R. MEYER, supra note 6, at $142-44$. A few women from the community accompanied the men to serve at the new prison camp. Id. at 143-44.

152. The land chosen for the Crow Creek Reservation was completely unsuitable. In the three years the Dakota spent there, many people starved because of scarce game, unsuitable soil, extended drought, and alkaline water. See I. HEARD, supra note 6, at 295. Others, weakened by near starvation, succumbed to disease. Some died from exposure because the government failed to supply adequate clothing, blankets, and shelter. See R. MEYER, supra note 6, at 146-53. In the spring of 1866, because of continued desperate conditions, the government moved the residents of Crow Creek to a new reservation in Nebraska Territory near the Niobrara River. There they were reunited with newly pardoned family members who had survived imprisonment at Camp McClellan in Davenport. See id. at 155-57. In 1863 when the prisoners were moved to Iowa and the rest of the community was sent to Crow Creek, a few Dakota were allowed to stay in Minnesota. Those remaining included mixed-blood scouts and their families, individuals who had testified against their fellow countrymen in the trials, and people who had never moved onto the reservations and were not involved in the war. See id. at 258-59. Over a period of several years many of the exiled Dakota gradually returned to their Minnesota homeland. Id. at 273. Some fled the horrors of Crow Creek almost immediately. Id. at 148. Travel was difficult. By the summer of 1863 , Minnesota had a $\$ 200$ bounty on Dakota 
Between the time of the executions in December 1862 and his death, President Lincoln received and granted requests to pardon a number of the remaining prisoners. Sibley himself submitted the first request in January 1863. He asked for the pardon of David Faribault, Jr., a mixed-blood who claimed to have participated in the fighting under duress, an assertion made by many of those convicted. Lincoln pardoned Faribault on May 11, 1863, "on evidence that he acted with the Indians under duress, and that he was not engaged in the massacre of women and children."153 At the same time, Lincoln pardoned Toonwanwakinyachatka, on the recommendation of the Judge Advocate General, because the record "was altogether too imperfect to justify the government in carrying the sentence into execution."154

On April 7, 1864, Reverend Riggs requested pardons for four prisoners who he believed had not participated in the fighting. ${ }^{155}$ Sibley concurred, noting that there was "reasonable doubt of the guilt of the prisoners named from circumstances that have transpired since their trial by the Military Commission, and ... they are entitled to the benefit of that doubt."156 Lincoln granted the pardon on April 19, 1864.157 On April 30, 1864, at the urging of Reverend Thomas Williamson, the President issued an order par-

scalps which, combined with revenge motives, made Dakota travel in Minnesota extremely dangerous. Dakota people who wished to return home to one of a few remaining safe havens had to travel by night and hide in ditches under cover during the day. Interview with Mrs. Vernell Wabasha, Lower Sioux Mdewakanton Community, in Morton, Minn. (July 23, 1989).

153. Gen. Order No. 120, May 11, 1863, in Military Orders, NARG 94; Letter from Brig. Gen. Henry Sibley to Pres. Abraham Lincoln (Jan. 26, 1863), accompanied by endorsements of J. Adv. Gen. Joseph Holt (Feb. 16, 1863) and pardon by Pres. Abraham Lincoln (May 11, 1863), in Letters and Telegrams Sent, NARG 393 (Entry 343) (also available in Court Martial Cases, NARG 153, File NN3132).

154. Gen. Order No. 120, May 11, 1863, in Military Orders, NARG 94; see Trial Transcripts, Case No. 105; Annotation of Recommendation of J. Adv. Gen. Joseph Holt, in Court Martial Cases, NARG 153, File NN3132. The evidence at trial consisted solely of the defendant's statement that he had fired one shot at the battle of Fort Ridgely and two shots at the battle of New Ulm. Yet nothing distinguishes this case from many others that resulted in convictions and death sentences. See, e.g., Trial Transcripts, Case No. 106 (only evidence was defendant's testimony that he fired one shot at the first battle of Fort Ridgely and two shots at Birch Coulee); Case No. 111 (only evidence was defendant's testimony that he took a few turnips at the Big Woods); Case No. 190 (only evidence was defendant's testimony that he fired two shots at the second battle of Fort Ridgely); Case No. 191 (only evidence was defendant's testimony that he fired one shot at the battle of New Ulm). There is no indication why Toonwanwakinyachatka was singled out for a pardon at this early date.

155. Letter from Rev. Stephen Riggs to Brig. Gen. Henry Sibley (Apr. 7, 1864), in Court Martial Cases, NARG 153, File NN3132. Riggs requested pardons for Eyojanjan (No. 237), Tahohpewakan (No. 238), Tapeytatanka (No. 95), and Weeyacha (No. 102). Eyojanjan and Tahoipewakan had been with Narcisse Freniere (No. 236)-who was acquitted-in a group "not shown to have been near to where any white man was killed, or to have participated at all in the massacres." Id. Tapeytatanka had testified at his trial that he had saved some escaping missionaries by preventing a group of Dakota from following their trail. The Commission had not believed him and had sentenced him to hang. Riggs confirmed that Tapeytatanka had told the truth. Id. Weeyooha had been acquitted by the Commission and released but had afterwards been condemned on evidence which Riggs said appeared "to have been vindictive in its character." Id.

156. Notation by Brig. Gen. Henry Sibley (Apr. 8, 1864), in Court Martial Cases, NARG 153, File NN3132.

157. Notation by Pres. Abraham Lincoln (Apr. 19, 1864), in Court Martial Cases, NARG 153, File NN3132. 
doning twenty-six more prisoners, ${ }^{158}$ and on August 27, 1864, the commander of the Camp in Davenport received an order pardoning Tatememah, apparently the same prisoner saved from the gallows just days before the execution. ${ }^{159}$ The pardon of one prisoner, Wambditanka (Big Eagle), was delayed by official skepticism of the pardon document, a penciled note from Lincoln on the back of a letter. ${ }^{160}$ Apparently the confusion was resolved because Wambditanka was later released. ${ }^{161}$

Beginning as early as July 1865, after two years of imprisonment at Camp McClellan, there was discussion about releasing the remaining prisoners, in part "because of the expense of feeding them and guarding them."162 General Pope expressed some reluctance about releasing the men and allowing them the freedom to join with what he termed other "hostile Indians" near the Crow Creek Reservation. ${ }^{163}$ Nevertheless, orders arrived in late September to transport the men as soon as spring navigation opened. Finally, on March 22, 1866, President Johnson ordered remission of the sentences of death and release of the 177 remaining prisoners. ${ }^{164}$ They, along with the community from Crow Creek, were transported to the Niobrara Reservation, newly appropriated for them in the northeast corner of the Nebraska Territory. ${ }^{165}$

\section{F. Later Trials}

The Army convened additional military commissions in 1863 and 1864 to try three more Dakota captured well after the fighting ended in September

158. Order for Pardon of Sioux Indians, Apr. 30, 1864, reprinted in 7 COLLECTED Worus of ABRAham Lincoln, supra note 104, at 325-26. Despite the official pardons, these and other pardoned Dakota had difficulty returning to their families. Once released, the men apparently were not eligible to receive further supplies from the Army and had no way to support themselves locally or to travel to reunite with their families. If they could somehow provision themselves for that journey, they were then in danger of being killed on the trip. Three prisoners were held as long as eight months after being pardoned because no provision was made for them once released. Letter from Rev. Thomas Williamson to Brig. Gen. Henry Sibley (Dec. 15, 1864), in Indian Prisoners, NARG 94 (Entry 173); Letter from Capt. George Judd to Brig. Gen. Henry Sibley (Aug. 27, 1864), in id.

159. See text accompanying note 128 supra. The spellings of the names differed, but the release order probably referred to the same individual.

160. On October 26, 1864, President Lincoln met with one George Dow, who must have inquired about Wambditanka. Lincoln wrote, in pencil, on the back of Dow's letter of introduction, "Let the Indian 'Big Eagle' now confined at Davenport, Iowa be discharged at once." When Dow presented this pardon to the commander of the camp in Davenport, he and the order were treated "with much rudeness and contempt." Letter from George Dow to Maj. Gen. John Pope (Oct. 31, 1864), in Indian Prisoners, NARG 94 (Entry 173).

161. See Letter from Rev. Thomas Williamson to Brig. Gen. Henry Sibley (Dec. 15, 1864), in Indian Prisoners, NARG 94 (Entry 173).

162. Letter from Congressman H. Price to Sec'y of War Edwin Stanton (July 8, 1865), in Letters Rec'd-Adj. Gen., NARG 94 (M619, roll 483).

163. Letter from J. Adv. Gen. Joseph Holt to Sec'y of War Edwin Stanton (Sept. 22, 1865), in Court Martial Cases, NARG 153, File NN3132 (also available in Letters Rec'd-Adj. Gen., NARG 94 (M619)).

164. Gen. Ct. Martial Order No. 86, Mar. 22, 1866, in Military Orders, NARG 94.

165. See note 152 supra. 
1862. These later trials and their review differed significantly from the trials conducted in 1862 .

The first to be tried was Wowinape, the sixteen-year-old son of Taoyateduta. After the end of the fighting in September 1862, Taoyateduta and a small group of followers had fled north, but he, his son, and several others later returned to the vicinity of Mankato. ${ }^{166}$ On July 3, 1863, Taoyateduta and Wowinape were surprised by two settlers while picking berries. The settlers shot and killed Taoyateduta; 167 Wowinape temporarily escaped, but was captured several weeks later. ${ }^{168}$ On August 22, 1863, Sibley ordered the formation of a military commission at Fort Abercrombie to try Wowinape. 169

Wowinape was tried on the general charge of participating in the murders and massacres between August 18 and September 23, 1862, and for attempted murder and horse stealing at frontier settlements near Devil's Lake in May, June, or July $1863 .{ }^{170}$ Mixed-blood witnesses testified that Wowinape had been present at the second battle of New Ulm, as well as at fighting in the Big Woods and Hutchinson. ${ }^{171}$ Others described Wowinape's capture and his statement that he and his father had come to steal horses. 172 The trial concluded on September 28, 1863, with a guilty verdict and a sentence of death by hanging. ${ }^{173}$ Sibley, as the officer convening the Commis-

166. See generally G. ANDERSON, supra note 6, at 164-77. Taoyateduta and 16 of his followers returned to Minnesota in June 1863. K. CARLEY, supra note 6, at 83-84; M. SATTERLEE, supra note 6 , at 81. Taoyateduta told several people he was returning to kill more Americans but told his son that he was returning to steal horses that they needed to maintain their existence on the plains. G. ANDERSON, supra note 6, at 176-77.

167. The desire for revenge and a bounty on Dakota scalps motivated violence against the Dakota. See note 152 supra.

168. Transcript of the Commission Proceedings in Trial of Wo-we-na-pa, in Court Martial Cases, NARG 153, File NN3132 (also available in Sioux War Trials, MHS P1423).

169. Spec. Order No. 300, Aug. 22, 1863, in Court Martial Cases, NARG 153, File NN3132. The order specified trial of three prisoners in addition to Wowinape, but I have found a record only of Wowinape's trial.

170. Transcript of the Commission Proceedings in Trial of Wo-we-na-pa, in Court Martial Cases, NARG 153, File NN3132.

171. Among the witnesses was David Faribault, Jr., who had been convicted in the first trials and had only recently been pardoned by the President. See text accompanying note 153 supra. During Wowinape's trial, Faribault was asked by a member of the Commission where he had been during the battle of Wood Lake; had Faribault answered, he might have incriminated himself. The transcript reflects that the Commission then went into private session and determined that the question should not be answered. See Transcript of the Commission Proceedings in the Trial of Wo-wena-pa, in Court Martial Cases, NARG 153, File NN3132.

172. Transcript of the Commission Proceedings in the Trial of Wo-we-na-pa, in Court Martial Cases, NARG 153, File NN3132.

173. The Commission recessed from August 25, 1863 to September 23, 1863 to move its proceedings from Fort Abercrombie to Fort Snelling in order to hear from witnesses more readily available there. Spec. Order No. 303, Aug. 25, 1863, in Court Martial Cases, NARG 153, File NN3132. Nathan Lamson, one of the settlers who had discovered Wowinape and Taoyateduta, served as a witness against Wowinape. Lieutenant Colonel Jennison had previously written to Sibley suggesting that the Commission hear Lamson's testimony because, according to Jennison, Lamson claimed that Wowinape had shot at him just as he shot at Taoyateduta. Jennison suggested that this proved "the "boy' to be no such innocent lad as might otherwise be believed." Letter from Lt. Col. Samuel Jennison to Brig. Gen. Henry Sibley (Sept. 8, 1863), in Letters Rec'd, NARG 393 (Entry 346). Lamson ultimately testified only that he thought that all the shots fired at him could not have been fired by 
sion, approved the sentence. ${ }^{174}$

To this point, Wowinape's trial closely resembled the earlier trials, but the subsequent review took an unusual turn. After Sibley indicated his approval of the finding and sentence, Major General Pope forwarded the proceedings to the Secretary of War and then to Judge Advocate General Holt. Instead of reviewing the trial, however, these officials returned the transcript to Pope with a reference to army regulations and to a statute effective December 24, 1861, that required the General Commanding the Army in the Field (Pope, in this case) to confirm or disapprove the proceedings. Pope's neutral "referral" was not enough. ${ }^{175}$ The same statute and regulations had been in effect in November 1862, but no one sought Pope's official approval at that time.

Given Pope's vociferously expressed intention to exterminate the Dakota or drive them out entirely, ${ }^{176}$ one would have expected him to confirm the proceedings without hesitation. Instead, with a sudden display of concern for legal nicety, Pope found a "technical difficulty" that prevented him from confirming the proceedings. ${ }^{177}$ Article 65 of the Articles of War, as amended in 1830, specified that an officer otherwise authorized to convene a court-martial could not do so if he were also the "accuser or prosecutor."178 An officer was the "accuser" if he either originated the charge or adopted and became responsible for it, unless he acted solely in an official capacity to order an investigation after facts warranting such an investigation were brought to his attention. ${ }^{179}$ The amendment to article 65 was designed to avoid the impropriety or the appearance of impropriety that exists when the individual passing on a court-martial proceeding might be biased because he also brought the charges. ${ }^{180}$ Although article 65 referred by its terms only to courts-martial, and not to military commissions, Pope suggested that it

one man, although Wowinape, in his statement, had claimed that his father was the only one who had fired. The adjournment also permitted testimony from mixed-bloods who were serving as scouts for Sibley's 1863 expedition against the Dakota who had fled north after the war. See Letter from 1st Lt. and J. Adv. Frank Pratt to Lt. Col. Samuel Jennison, Pres. of the Military Comm'n (Aug. 25, 1863), in Court Martial Cases, NARG 153, File NN3132.

174. See Endorsements to Wowinape Trial Transcript (Oct. 1, 1863) (Sibley's approval), in Court Martial Cases, NARG 153, File NN3132.

175. See id. at Oct. 8, 1863 (Pope's referral to the President); id. at Oct. 11, 1863 (forwarded by General-in-Chief Halleck to Secretary of War Stanton); id. at Oct. 12, 1863 (referred to Judge Advocate General Holt by Secretary of War); id. at Oct. 13, 1863 (returned to Secretary of War with Holt's remarks on requiring confirmation); id. at Oct. 16, 1863 (returned to General Pope by the Secretary of War with remarks of Judge Advocate General).

176. See text accompanying note 60 supra.

177. Letter from Maj. Gen. John Pope to J. Adv. Gen. Joseph Holt (Oct. 29, 1863), in Court Martial Cases, NARG 153, File NN3132. Pope developed greater sympathy for the Indians as he became more familiar with their condition and treatment, and he advocated substantial reforms in federal policy towards them. R. ELIIS, supra note 53, at 39-44. Perhaps this new-found perspective sensitized him to the plight of the Dakota by the time he was asked to review the trial of Wowinape, though it did not prevent him from approving the later trials of Wakanozanzan and Shakopee. See text accompanying notes $198-200$ infra.

178. Act of May 29, 1830, ch. 179, § 1, 4 Stat. 417.

179. 1 W. WINTHROP, MiLITARY LAW 68-69 (1886).

180. Id. at $67 \&$ n.4. 
might apply here, too, by analogy. Believing that the proceedings against Wowinape were "in violation of the spirit of the 65th Article of War, but [that] there ... [was] a possible doubt," he submitted the matter for decision to Judge Advocate General Holt. ${ }^{181}$ Holt agreed that article 65 had been violated in spirit, ${ }^{182}$ and Pope thereafter disapproved the proceedings. ${ }^{183}$

Upon hearing of Pope's disapproval of Wowinape's trial, Sibley wrote to Holt to justify his own actions. He noted, quite accurately, that "a precisely similar condition of things existed in 1862, when nearly four hundred Indian warriors, taken prisoners by the forces under my command, were tried and the greater number condemned to death by a Military Commission ordered by me upon charges and specifications preferred by myself." 184 If Wowinape's trial was irregular and subject to disapproval, so, too, were the earlier trials. Sibley argued that the provision was designed only to protect inferior officers from the prejudice their superiors might feel toward them, and such hostility could not be "pre-supposed to exist" where the defendants were enlisted men or prisoners of war. ${ }^{185}$ Sibley's superiors disagreed. Despite the disapproval of the proceedings, however, Wowinape was not released but was sent to Camp McClellan to be confined with the other prisoners "until the President shall act upon the case."186

The other two Dakota tried by military commission in 1864 were less fortunate. Wakanozanzan and Shakopee, both chiefs who had fled north with Taoyateduta, were kidnapped from Canadian soil in January 1864 by British soldiers. ${ }^{187}$ In May the two prisoners were taken to Fort Snelling, where, on November 14, Sibley convened a military commission. ${ }^{188}$ On November 25 , the Commission formally charged Wakanozanzan with murdering Philander Prescott and "sundry white men[,] women and children whose names are unknown," and with participating in the "murders[,] massacres

181. Letter from Maj. Gen. John Pope to J. Adv. Gen. Joseph Holt (Oct. 29, 1863), in Court Martial Cases, NARG 153, File NN3132.

182. J. Adv. Gen. Joseph Holt to Maj. Gen. John Pope (Nov. 3, 1863), inscribed on back of Letter from Maj. Gen. John Pope to J. Adv. Gen. Joseph Holt (Oct. 29, 1863), supra note 177. Holt agreed that the Articles of War did not, by their own terms, apply to the trial of Wowinape but that "the reasons for the law" would nonetheless support its applicability. He concluded that "sufficient ground is established to justify a disapproval of the proceedings." Id. 177.

183. Letter from Maj. Gen. John Pope to J. Adv. Gen. Joseph Holt (Oct. 29, 1863), supra note

184. Letter from Brig. Gen. Henry Sibley to J. Adv. Gen. Joseph Holt (Dec. 7, 1863), in Sioux War Trials, MHS P1423.

185. Id.

186. See Endorsements to Wowinape Trial Transcript (Nov. 13, 1863), in Court Martial Cases, NARG 153, File NN3132 (also available in Sioux War Trials, MHS P1423).

187. See 2 W. Folwell, supra note 6 , at $293,443-44$. The British soldiers acted at the behest of Major Edwin Hatch, who had been authorized, over the objections of both Pope and Sibley, to raise an independent battalion to fight the remaining Dakota who had fled north and had engaged in skirmishes with American settlers. Hatch had no authority to cross onto Canadian soil to capture the two Dakota, so he resorted to soliciting the unofficial aid of the British soldiers. Id. 290, 293, 443-44.

188. Folwell suggests that the delay in convening the Commission was due to the absence of many of Sibley's troops and the consequent difficulty in finding sufficient numbers of commissioned officers to serve on the panel. Id. at 445. 
and other outrages committed by the Sioux Indians upon the white settlers of the State of Minnesota."189 In a departure from the earlier trials, each specification recited that Wakanozanzan was "a Sioux Indian of a band under the protection ... of the United States," perhaps reflecting an awakened sensibility to the sovereignty questions raised by the trials. ${ }^{190}$ At the outset, Wakanozanzan asked for permission to introduce counsel. The request was granted, but only after a day's adjournment to seek guidance from headquarters. The proceedings were then continued for two days at the defendant's request. When the court reconvened, Wakanozanzan still did not have counsel present but said that he was ready to proceed. ${ }^{191}$

Five witnesses testified against Wakanozanzan-one American woman and four Dakota - none of whom actually had seen the defendant kill anyone. Witnesses testified that Wakanozanzan had favored killing whites, that he willingly had gone out with war parties and had led some of them, that he had boasted of killing whites, that he had threatened "civilized" and "friendly" Indians if they didn't join the fight, and that he was a member of the group that had killed Philander Prescott. ${ }^{192}$

The defendant offered no evidence but requested time to prepare a final defense. The Commission adjourned for two days, at which time Wakanozanzan submitted a written statement prepared by two attorneys, ex-Governor Willis A. Gorman and future Senator and Governor Cushman $\mathbb{K}$. Davis. ${ }^{193}$ The statement challenged the jurisdiction of the court because Wakanozanzan had been seized from a foreign state, and it denied that he

189. Transcript of the Commission Proceeding in the Trial of Tahtaechashnahmanne, in Court Martial Cases, NARG 153, File NN3132. The transcript refers to the defendant as "Tahta-e-chashnah-manne alias Medicine Bottle." It is unclear why the Dakota name used in the transcript differs from the one by which the defendant was generally known (Wakanozanzan).

190. See generally Part IV infra.

191. Transcript of the Commission Proceeding in the Trial of Tahtaechashnahmanne, in Court Martial Cases, NARG 153, File NN3132; Letter from J. Adv. Morrison to Ass't Adj. Gen. Rollin Olin (Nov. 25, 1864), in Indian Prisoners, NARG 94 (Entry 173).

192. Transcript of the Commission Proceeding in the Trial of Tahtaechashnahmanne, in Court Martial Cases, NARG 153, File NN3132. A member of the Commission demonstrated a special concern for the status of the Dakota by asking one Dakota witness if Wakanozanzan and his band were under the protection of the United States. The witness acknowledged that they were "annuity Indians" and under such protection. "Annuity Indian" referred to those Dakota who received annual payments pursuant to the Treaties of 1851 and 1858, in which the Sisseton, Wahpeton, Wahpekute, and Mdewankanton sold large tracts of land in exchange for lump sum and annual payments to the bands, to be distributed to individual tribe members. See text following note 5 supra.

193. Transcript of the Commission Proceeding in the Trial of Tahtaechashnahmanne, in Court Martial Cases, NARG 153, File NN3132. Gorman was better known than Davis, having served as territorial governor of Minnesota from 1853 to 1857 and as a delegate to the state constitutional convention. He had dealt with the Dakota earlier when they were removed to the Redwood and Yellow Medicine Reservations after the treaty of 1851. Baker, supra note 61, at 51-53; Life and Public Services of Hon. Willis A. Gorman, in 3 Collections of THE MinNesota Historical SOCIETY 314, 318-21 (1880). Gorman's prior experiences suggest some of his motivations in assisting both Wakanozanzan and Shakopee, an act probably unpopular in the Minnesota community. While serving as commander of a military division in Arkansas during the Civil War, Gorman established "a sort of court of civil jurisdiction, which was ordered to proceed according to . . . the common law," apparently in an effort to subordinate the military to the civil law. Baker, supra note 61, at 57. At the time of Gorman's death, Davis noted in his eulogy that Gorman had always favored civilian law over military power. Life and Public Services of Hon. Willis A. Gorman, supra, at 329. In repre- 
had participated in the events charged or that he told anyone that he had been connected with Prescott's death. The Commission returned guilty verdicts on both charges-murder and participation in the fighting-but found Wakanozanzan not guilty of the specification of killing United States soldiers. ${ }^{194}$

The proceedings against Shakopee began immediately after Wakanozanzan's trial concluded. ${ }^{195}$ Shakopee, too, asked for time to introduce counsel, and the Commission granted a one-day adjournment. When the proceedings resumed, Shakopee stated that Mr. Gorman had agreed to defend him, but would not be available until December 9, six days later. Shakopee asked for another adjournment until that date, but the Commission denied the request. Shakopee was then tried on charges of murder and "general participation in the murders[,] massacres and other outrages." The specifications charged various acts of killing, with an "unknown murderous weapon," various unidentified white men, women, and children. As with Wakanozanzan, the specifications recited that Shakopee acted "with other Indians of the same tribe under the protection of the United States." At the outset of their testimony, each of the six witnesses, all Dakota, stated that Shakopee was an "annuity Indian" and under the protection of the United States, an issue previously raised only in the trial of Wakanozanzan. As in the trial of Wakanozanzan, none of the witnesses had actually seen Shakopee do anything, but each repeated what Shakopee had told others about various killings. Shakopee submitted a written statement denying that he had fought against the whites or had claimed to have killed any of them. The Commission then issued its verdict, finding him guilty of both charges-murder and general participation in the fighting - but, as with Wakanozanzan, not guilty of the two specifications charging him with shooting at and killing soldiers. ${ }^{196}$

The Commission sentenced both Wakanozanzan and Shakopee to be hanged. Sibley confirmed the sentences on December 14, 1864, and set execution for January 20, 1865. He forwarded the proceedings to Judge Advocate General Holt with a notation that the two were "chiefs of two of the bands most deeply implicated" in the war, that it was a matter of notoriety that these men "not only [led] in instigating their people to attack the whites, but in personal participation in the indiscriminate butchery of men, women and children." He noted that British subjects, not American soldiers or citi-

senting Wakanozanzan and Shakopee, Gorman apparently was continuing his efforts to subordinate military authority to civil law.

194. Transcript of the Commission Proceeding in the Trial of Tahtaechashnahmanne, in Court Martial Cases, NARG 153, File NN3132.

195. Transcript of the Commission Proceeding in the Trial of Shakopee, in Court Martial Cases, NARG 153, File NN3132.

196. Id. The verdict also struck from the charges and specifications the allegation that Shakopee had acted "in company with other Indians of the same tribe," the indication of the counties in which certain acts had occurred, the statement that one family Shakopee killed had "three or more" women and children, and the description that Shakopee's participation in the "murders, massacres and other outrages" had been "general." Id. No explanation was given for the changes. 
zens, had kidnapped the defendants and that the escape of these two from punishment "would have a very bad effect upon the Indians generally."197

Two weeks later, on December 27, 1864, Holt returned the proceedings to General Pope for his confirmation in order to comply with the requirement, first noted after the trial of Wowinape, that the general commanding the army in the field confirm or disapprove the proceedings. ${ }^{198}$ Pope confirmed the judgments on January 20,1865,199 ignoring the defect that had caused him to disapprove Wowinape's trial, though these trials suffered from the same infirmity. ${ }^{200}$ In March, Holt reviewed the transcripts and the challenge to jurisdiction, and he strongly recommended to President Lincoln that the executions be carried out. ${ }^{201}$

On August 29, 1865, President Johnson, who had taken office after Lincoln's assassination, approved the sentences. The executions were scheduled for October 11, but Johnson postponed them the day before on the recommendation of the Secretary of the Interior, who had received a plea from Bishop Grace of St. Paul. ${ }^{202}$ Holt again recommended execution, pointing to the major part these individuals had played in the fighting as described in Sibley's earlier letter. ${ }^{203}$ The two Dakota were hanged at Fort Snelling on November 11, 1865.204

\section{Fairness of the Proceedings}

\section{A. Procedural and Evidentiary Defects}

\section{Rapidity of the trials.}

It has become a commonplace observation that the United States-Dakota war trials were unfair. ${ }^{205}$ The Commission conducted the trials very rapidly,

197. Letter from Brig. Gen. Henry Sibley to J. Adv. Gen. Joseph Holt (Dec. 14, 1864), in Court Martial Cases, NARG 153, File NN3132 (also available in Sioux War Trials, MHS P1423).

198. Letter from J. Adv. Gen. Joseph Holt to Maj. Gen. John Pope (Dec. 27, 1864), in Court Martial Cases, NARG 153, File NN3132; see text accompanying note 175 supra.

199. Endorsement to Transcript of the Commission Proceeding in the Trial of Shakopee, in Court Martial Cases, NARG 153, File NN3132.

200. See text accompanying notes 176-183 supra. The record contains no explanation of the different results and no indication that Pope or his superiors even detected the parallel. Perhaps sympathy for the position of the 16-year-old Wowinape, who had done no more than fight in battles, may have been a factor leading to Pope's disapproval on technical grounds; no such sympathy would have attached to those seen as leaders of the war.

201. Letter from J. Adv. Gen. Joseph Holt to Pres. Abraham Lincoln (Mar. 25, 1865), in Court Martial Cases, NARG 153, File NN3132. With respect to Shakopee, Holt noted particularly that "the prisoner is shown to have been one of a tribe of Indians receiving an annuity from the government of the United States," id., again obliquely raising the issue of sovereignty status.

202. Letter from Sec'y of the Interior James Harlan to Sec'y of War Edwin Stanton (Oct. 10, 1865), in Court Martial Cases, NARG 153, File NN3132; Letter from Pres. Andrew Johnson to Sec'y of War Edwin Stanton (Oct. 10, 1865), in $i d$.

203. Letter from J. Adv. Gen. Joseph Holt to Sec'y of War Edwin Stanton (Nov. 7, 1865), in Court Martial Cases, NARG 153, File NN3132 (quoting Letter from Brig. Gen. Henry Sibley to J. Adv. Gen. Joseph Holt (Dec. 14, 1864), supra note 197).

204. Letter from Ass't Adj. Gen. H. Clay Wood to Sec'y of War Edwin Stanton (Nov. 20, 1865), in Court Martial Cases, NARG 153, File NN3132.

205. See, e.g., G. ANDERSON, supra note 6, at 164-65; K. CARLEY, supra note 6, at 69; M. SATTERLEE, supra note 6 , at $17,79$. 
with as many as thirty or forty trials in a single day. After hearing the evidence, the Commission would clear the room, deliberate for a few minutes, and announce the verdict. With the exception of the first case, it appears that the Commission had little trouble reaching its verdicts. Isaac Heard, the Recorder for the Commission, attempted to justify the speed: "The trials," he said, "were elaborately conducted until the commission became acquainted with the details of the different outrages and battles, and then, the only point being the connection of the prisoner with them, five minutes would dispose of a case."206

Even Reverend Riggs, who assisted the Commission by securing information from the Dakota, was appalled at the speed of the trials. In a letter to the St. Paul Daily Press, he wrote, "Many of those that are tried and condemned, are doubtless guilty of participation in the murders and outrages committed on the Minnesota frontiers-some of them as guilty as Satan himself, and richly deserving the punishment of death. ... [Nonetheless, a] military commission, where the cases of forty men are passed upon in six or seven hours, is not the place for the . . clear bringing out of evidence and securing a fair trial to every one."207 Bishop Whipple wrote to the Secretary of the Interior that "[o]fficers of the highest character who were present at the trial have assured me that ... [the Commission] could not and did not make a careful examination." 208 Reverend J.P. Williamson noted that "400 have been tried in less time than is general[ly] taken in our courts with the trial of a single murderer."209

\section{Cultural misunderstanding and deficiencies of the evidence.}

To say, as many have, that the trials were unfair because they were conducted too quickly only skims the surface of the imperfections. A detailed look at the trial transcripts produces a more precise understanding of the nature of the unfairness. In most of the first few cases, the defendants were charged with attacking individual wagons of settlers and murdering one or more of the men in the wagons. Among the witnesses called were women who had been in those wagons, had witnessed the attacks, and had been held captive in the Dakota camp until released with all the American prisoners at the end of September. ${ }^{210}$ This evidence was the best sort presented-eyewitness testimony to particular acts of killing.

As the trials progressed, however, there was less and less of such evi-

206. I. HEARD, supra note 6, at 25455. Although the first few cases appeared to take longer than many of those that followed, one could hardly call them "elaborate." The length of the trial seemed to depend more upon the length of the statement made by the defendant than on the nature of the other evidence presented.

207. St. Paul Daily Press, Nov. 29, 1862, at 1, col. 4.

208. Letter from Bishop Henry Whipple to Ass't Sec'y of the Interior John Usher (Apr. 21, 1863), in Whipple Papers, MHS. MHS.

209. Letter from Rev. John Williamson to S.B. Treat (Nov. 5, 1862), in ABCFM Papers,

210. See, eg., Trial Transcripts, Case No. 2 (Tehehdonecha), Case No. 3 (Wechankwashtodopee). 
dence. Many defendants admitted to being at a battle, and that evidence alone was enough to bring a conviction. Others admitted that they were with a group when another individual killed a settler, and that, too, brought conviction. Testimony from other witnesses tended to be short, serving merely to identify the prisoner as having been present at particular battles or when particular individuals were attacked, but the witnesses often had no direct knowledge of who struck the fatal blows. In many cases, the only evidence against the defendant was testimony from the white women captives or mixed-bloods that the defendant had appeared to go willingly into battle, "whooping around" with the rest, and had boasted afterward about the number of people he had killed in the fighting. ${ }^{211}$

Although evidence of the prisoners' boastful statements was admissible as a confession, ${ }^{212}$ the reliability of such remarks is highly suspect in ways that were never suggested at the trials. Boasting about exploits, exaggerated as well as real, would have been an expected part of the aftermath of any battle. Such exaggeration was particularly likely to occur in this war, because the Dakota disagreed about whether to go to war and many men might have desired to prove their loyalty by describing and embellishing their exploits. ${ }^{213}$ Special acts of bravery, such as touching an armed soldier during battle or sneaking into an enemy camp to steal or release horses, were considered "counting coup,"214 and might have been boasted of in a manner suggesting that killings had occurred.215 Moreover, according to Dakota custom, the man who struck the mortal blow was not the only one entitled to claim a kill in battle. "It was considered most honorable to be the first to

211. See, e.g., Trial Transcripts, Case No. 1 (Godfrey).

212. Hearsay was generally excluded from use in courts-martial, but voluntary confessions were admissible. $1 \mathrm{~W}$. WINTHROP, supra note 179 , at $459,463$.

213. See, e.g., St. Paul Pioneer, Oct. 14, 1865, at 2, col. 1 (suggesting that Shakopee had a "motive ... for ... telling an untruth" in saying that he had killed white settlers in response to Taoyateduta's question "[W]here have you been all day?"); Trial Transcripts, Case No. 1 (Godfrey) (defendant testified that he was told that those who did not go out on raids would be killed), Case No. 3 (Wechankwashtodopee) (defendant said he had "snapped gun" at victim because another asked if he was afraid), Case No. 6 (Hinhanshoonkoyagmane) (defendant testified that he was told that he would be killed if he didn't go to battle), Case No. 8 (Charles Crawford) (defendant testified that Taoyateduta said that every mixed-blood and Indian must go to battle or be killed). One example of the pressure to embellish exploits was recounted by Thomas A. Robertson (Case No. 135), a mixed-blood who was tried and acquitted on the charge of killing a man at Fort Ridgely. Robertson reported later that he was instructed by a member of the soldiers' lodge to shoot a burning arrow in order to start a fire and felt he must comply. A friend, apparently seeking to protect him, "nudged me and pointing out of the window said, 'There goes a man[] shoot and I will say you killed him." " Robertson fired, and the friend declared " "He shot him down. He shot him down." " Reminiscences of Thomas A. Robertson, supra note 124, at 25.

214. 2 George Bird Grinneld, The Cheyenne Indians $29-38$ (1923); M. Satterlee, supra note 6, at 118-19; Robert F. Spencer, Jesse D. Jennings, Charles E. Dibble, Elden Johnson, ARDEN R. King, THEODORE Stern, KenNeTH STEWART \& William J. WALlis, The NATIVE AMERICANS 346 (2d ed. 1977).

215. See, e.g., Trial Transcripts, Case No. 383 (Wakinyanna) (witness testified that defendant said he killed two boys with his war lance in house near Traveller's Home; defendant testified only that he might have "done it"-he touched one with his "flute" but did not use his lance), Case No. 333 (Hataninkoo) (witness testified that the defendant said he killed someone with an axe; defendant testified that others shot the man and he struck the victim only after he was dead). 
touch an enemy, but the three next following were accounted as having helped kill him, though he might be dead before they reached him."216 The man who first touched an enemy was also credited with having killed him, even if the actual killing was done by another, and the one who first entered a house where people were later killed by any of the group was given credit for all the killings. ${ }^{217}$

Thus, when individuals boasted of killings, they might have been exaggerating or they might have meant no more than that they were present at the time of a killing and had performed acts of valor. ${ }^{218}$ In many of the cases, moreover, the testimony about the defendants' "confessions" came from Americans captured in the early days of the war, witnesses who may not have understood these distinctions, even assuming they understood the Dakota language well enough to interpret the defendants' remarks correctly. At trial, then, a defendant might truthfully have denied-as many didactually killing anyone, but the court would likely have considered the response untruthful in view of the testimony about the defendant's own "confession." Because no one suggested the potential for such cultural misunderstanding at the time of the trials, however, the Commission made no effort to explore the possible meanings of the defendants' statements.

Nonetheless, many of the defendants admitted at least that they were present when individuals were killed by other Dakota. If the Commission regarded those particular killings as murders, it might conclude that all members of the group present were equally liable, analogizing to the common law doctrine of felony murder. ${ }^{219}$ Evidence might then be sufficient to convict even though it failed to distinguish between the one who struck the blow and others who were present. But it is not clear how, if at all, the felony-murder doctrine should apply to acts committed during a time of war: If a group could, under the laws of war, legitimately set out with weapons to kill soldiers and to run settlers off strategic land, ${ }^{220}$ particular killings by members of the group would not have been done in the commission or attempted commission of a felony, a requirement of the felony-murder doctrine.221 Again, however, these questions were not raised at the trials.

216. Samuel W. Pond, The Dakota or Sioux in Minnesota As Thex Were In 1834, at 128 (1986); see also 2 G. GRINNELI, supra note 214, at 30 (when an enemy was killed, many would try to be the first to touch him, and those following would also strike the body).

217. I. HEARD, supra note 6, at 189. Godfrey, whose Dakota name, Otakle, was reported to mean "he who kills many," testified that he had been given that name because many people were killed in a house that he entered first, but he had only struck one man on his shoulder with the back of a hatchet. See Trial Transcripts, Case No. 1.

218. Reverend Stephen Riggs reported that most of the condemned prisoners denied committing acts warranting a death sentence. "But their ideas of this are very strange," he said. "One man, who acknowledges he helped kill a number says if he had killed one all himself he would think it right that he should die." Letter from Rev. Stephen R. Riggs to Mary Ann Riggs (Dec. 23, 1862), in Riggs Letters, WPA-Chippewa County Project, MHS. One wonders if those "strange ideas" reflected the distinction between counting coup and actual killing.

219. See generally Wayne R. LaFave \& Austin W. ScotT, JR., Criminal Law $622-41$ (1986).

220. See Part IV infra.

221. See W. LAFAVE \& A. ScotT, supra note 219 , at 632-37. 
If the Commission had considered whether the evidence it heard could point to different levels of involvement and guilt, it might at least have concluded that different forms of participation warranted different punishments. Instead, Sibley expressly instructed the Commission to consider solely whether the individual voluntarily participated in the fighting. "The degree of guilt was not one of the objects to be attained."222 The Commission likewise ignored mitigating evidence that particular defendants had acted to protect the victims of attack from being raped or killed.223

\section{Self-interest of the witnesses.}

Much of the evidence in the trials came from individuals who were themselves on trial for their lives, mostly mixed-bloods and others who had adopted American ways. The most often mentioned of these defendantsturned-witnesses was Godfrey, also called Otakle, the "Mulatto" specifically described in the order forming the Commission. ${ }^{224}$ In his own trial, Godfrey claimed that he had been forced into battle by threats against his family and had not actually killed anyone. Although Godfrey was the first to be tried, the Commission held his case open for some time, asked for his testimony in subsequent cases, and suspended imposition of his sentence until it completed the trials.

Godfrey gave evidence in fifty-five of the cases; of the thirty-eight Dakota who were ultimately hanged, he testified in the trials of eleven.225 Reverend Riggs noted that Godfrey "was convicted among the first batch. But he was everywhere in all the battles and ... [later wanted] to convict everyone else."226 The Commission also questioned subsequent prisoners and witnesses about Godfrey, but found "no person who saw him kill anyone."227 Ultimately, the court found him not guilty of the charge of murdering seven unknown whites, but convicted him of participating in the fighting and sentenced him to be hanged. The court's gratitude for Godfrey's cooperation

222. Letter from Brig. Gen. Henry Sibley to Ass't Sec'y of the Interior John P. Usher (Dec. 19, 1862), in Letters and Telegrams Sent, NARG 393 (Entry 343). Sibley went on to note that "it would have been impossible to devote" sufficient time to ascertain the degree of guilt in each of so many cases. Id.

223. See, e.g., Trial Transcripts, Case No. 24 (defendant testified that he saved Miss Williams' life; corroborated by witness), Case No. 356 (defendant testified that he saved the lives of many women because they had treated him well; witness testified that defendant saved a woman, two children, and oxen), Case No. 359 (defendant testified that he saved a voman's life; corroborated by witness). All three of these defendants were sentenced to hang, and defendants numbered 24 and 359 were among the 38 executed on December 26, 1862.

224. See text accompanying note 56 supra. Godfrey was the son of a French Canadian and a black woman who had been a servant in the family of Alex Bailly, a fur trader. He was raised in the Bailly family. I. HEARD, supra note 6, at 191; THROUGH DAKOTA Eyes, supra note 6, at 85.

225. See Trial Transcripts, Case Nos. 10, 22, 35, 115, 210, 254, 327, 359, 377, 382, 383.

226. Letter from Rev. Stephen Riggs to Mary Ann Riggs (Oct. 20, 1862), in Riggs Letters, WPA-Chippewa County Project, MHS.

227. I. HEARD, supra note 6, at 254 (emphasis in original). The absence of eyewitness accounts of killing did not prevent the court from convicting and ordering the execution of many other prisoners based solely on testimony that witnesses had overheard the defendants boast of killings or participation in battles. See text accompanying note 211 supra. 
was reflected in a recommendation to the President that the sentence be commuted to ten years' imprisonment because he had given evidence against many other prisoners. Without his testimony, the Commission wrote, "a large number of men of the very worst character would have gone unpunished."228 The President agreed and spared Godfrey's life. ${ }^{229}$

Godfrey was the most noted witness, but others played similar roles. Thomas Robertson testified in fifty-five of the trials, including those of five of the thirty-eight executed, ${ }^{230}$ and was found not guilty in his own trial. ${ }^{231}$ Charles Crawford testified in eight trials ${ }^{232}$ and was himself tried twice and found not guilty each time. ${ }^{233}$ Wakanhdehota testified in seven trials, including one for a defendant who was hanged; ${ }^{234}$ his own first trial resulted in a sentence of death by hanging but that was later reduced to imprisonment for three years. ${ }^{235}$ Wechahpenompa testified in six trials, ${ }^{236}$ Louis LaBelle in four, ${ }^{237}$ Louis Frenier ${ }^{238}$ and Tazoo ${ }^{239}$ in three, and Henry Millard and Baptiste Campbell in one each. ${ }^{240}$ The Commission found all of these men guilty in their own trials, ${ }^{241}$ and the last three were hanged. David Faribault, Jr., described by one of the missionaries as a mixed-blood "of bad character, strongly suspected of instigating the Indians to these murders," 242 testified in many of the trials-the precise number is impossible to determine ${ }^{243}$-and was later pardoned.

The self-interest of these witnesses, and their anger and distress at being drawn into the war and forced to choose sides in the long-standing conflict between the "farmer Indians" and the traditional Dakota, suggest reasons to doubt their credibility. Their testimony was not always crucial to the outcome, as the defendants often had already admitted to acts of war that would have led to guilty verdicts. Still, the witnesses often were responsible

228. Trial Transcripts, Case No. 1, Memorandum by the Court to Brig. Gen. Henry Sibley (Nov. 5, 1862).

229. See S. ExEc. Doc. No. 7, supra note 116, at 2.

230. See, e.g., Trial Transcripts, Case Nos. 178, 279, 333, 342.

231. Trial Transcripts, Case No. 135.

232. Trial Transcripts, Case Nos. 50, 84, 102, 103, 157, 158, 169, 220.

233. Trial Transcripts, Case Nos. $8,136$.

234. Trial Transcripts, Case Nos. 278, 298, 309, 310, 313, 377, 378.

235. Trial Transcripts, Case Nos. 181, 277. Both of Wakanhdehota's trials appear to have occurred before he began to testify, but five of the trials in which he testified were held on the same day as his second trial, in which the Commission imposed a lesser sentence.

236. Trial Transcripts, Case Nos. $168,173,194,195,246,334$. Only one of these defendants was found guilty.

237. Trial Transcripts, Case Nos. 176, 236, 237, 238.

238. Trial Transcripts, Case Nos. $159,160,174$.

239. Trial Transcripts, Case Nos. 9, 24, 115.

240. Trial Transcripts, Case No. 13 (Henry Millard), Case No. 115 (Baptiste Campbell).

241. Trial Transcripts, Case No. 282 (Wechahpenompa), Case No. 139 (Louis LaBelle), Case No. 131 (Louis Freniere), Case No. 4 (Tazoo), Case No. 115 (Henry Millard), Case No. 138 (Baptiste Campbell). MHS.

242. Letter from Rev. Thomas Williamson to S.B. Treat (Nov. 21, 1862), in ABCFM Papers,

243. Both David Faribault, Sr. and David Faribault, Jr. testifed at the trials. The transcripts frequently do not specify which man testified, but "David Faribault" is listed as a witness in 84 of the trials. See Trial Transcripts passim. 
for evidence of the defendants' participation in attacks on individual settlers, which apparently led to their inclusion on Lincoln's execution list for having engaged in "massacres." 244

The testimony of these witnesses may, of course, have been truthful, but their own self-interest in avoiding punishment and their positions in the disputes within the Dakota community must lead to questions about their veracity-questions that the Commission itself never asked. Indeed, the Commission may have found these witnesses trustworthy precisely because they did cooperate and were therefore "good Indians" or "friendlies,"245 although the Commission nonetheless convicted some of them for their own participation in the fighting. Moreover, most of the regular witnesses were mixed-bloods, more likely to be believed than the full-blood defendants. In a letter to the St. Paul Pioneer, Reverend Riggs complained that the Commission might believe a mixed-blood who claimed he was forced to go into battle and, therefore, reduce his sentence; the Commission would not accept such a defense from a full-blood. ${ }^{246}$

\section{Defendants' misunderstanding and absence of counsel.}

It seems likely that the prisoners understood little about the nature and purpose of the trials. David Faribault, Jr., a mixed-blood, was a United States citizen, had been raised and educated among the whites, and was fluent in both English and French as well as Dakota. Nonetheless, in his request for pardon he stated that he had not understood the nature of the proceedings. He believed, he said, that the object of the Commission was "merely to ascertain what parties should be held for a regular trial to be had at some future time in the Courts of the country," and he did not know that he was on trial for his life. ${ }^{247}$ The rest of the Dakota prisoners, even more unfamiliar with American customs, almost surely did not know more. ${ }^{248}$ The exchange of communications between Father Ravoux and Sibley, and the message to the condemned delivered on December $22,{ }^{249}$ four days before the executions, suggest that not until that late date did the Dakota know the nature of the Commission's deliberations. Nor would the Dakota

244. See text accompanying note 118 supra.

245. See K. CARLeY, supra note 6, at $61,64,81$; M. SATterlee, supra note 6 , at $75,77$.

246. St. Paul Pioneer, Dec. 14, 1862, at 4, col. 3. Racism alone could probably account for the distrust of the full-bloods. In addition, the Commission members would have had more natural affinity for the mixed-bloods, who had usually been raised and educated in the white community.

247. Affidavit of David Faribault, Sr., in Court Martial Cases, NARG 153, File NN3132 (writing of his son's statements to him); see also Affidavit of Lt. Col. L.H. Fowler, id. (supporting Faribault's request for pardon). Faribault's belief is consistent with what Sibley may have first set out to do when he convened the Commission. See text accompanying notes 52-55 supra.

248. If the defendants did not know they were on trial, they might also have been unaware of just how much they were at the mercy of the Commission. Such a conclusion may lessen the strength of my suggestion that the testimony of those defendants who cooperated was suspect. See text accompanying notes 224-243 supra. On the other hand, the defendants probably knew that they were likely to be punished for their actions, especially as the trials progressed; they simply did not know the extent of the penalty being considered or that punishment was being determined by this Commission.

249. See text accompanying notes 123-126 supra. 
have been familiar with American trial procedures. Reverend John Williamson reported: "[The defendants know] nothing of the manner of conducting trials[,] if a mistake occurs they are unable to correct it. And often not understanding the English language in which the trial is conducted, they very imperfectly understand the evidence upon which they are convicted."250

The prisoners' lack of understanding might have been alleviated if counsel had been present to represent or advise them. Although the military considered the presence of defense counsel a privilege, not a right, ${ }^{251}$ courtsmartial generally admitted counsel as a matter of course. ${ }^{252}$ The Commission did not follow that rule here. St. André Durand Balcombe, government agent to the Winnebagos, apparently attempted to intervene and introduce counsel on behalf of ten or twelve Winnebagos tried in November 1862 for participating in the fighting with the Dakota; ${ }^{253}$ the Mankato Record reported that General Sibley "very respectfully but firmly replied that these were 'military trials," ' intimating that he would not comply with the request. ${ }^{254}$

Of the Dakota, only Wakanozanzan and Shakopee, tried in late 1864, requested permission to introduce counsel at their trials. The Commission granted the requests, but only after consulting with Sibley, ${ }_{2}^{255}$ who apparently had a change of heart since the Winnebago trials. The bulk of the Dakota prisoners, unfamiliar with American proceedings, probably did not think of seeking counsel; they likely would have been unable to find counsel even if Sibley would have permitted it. In the absence of counsel, the Judge Advocate was responsible both for prosecuting the case and assisting the accused in preparing his case. Even in a normal court-martial this assistance was recognized as inadequate. ${ }^{256}$ Relying on the prosecutor to act as counsel for the accused is yet more problematic where, as here, the Judge Advocate fought in the battles that led to the charges. Certainly the transcripts do not reflect that the Judge Advocate provided any protection or assistance to the defendants in these cases.

\section{Contemporaneous recognition of trial defects.}

Local missionaries and officials who reviewed the trial transcripts for President Lincoln voiced some of these criticisms at the time of the trials. Assistant Secretary of the Interior John P. Usher wrote to Sibley as early as December 10,1862, complaining about the "meagre manner in which the MHS.

250. Letter from Rev. John Williamson to S.B. Treat (Nov. 5, 1862), in ABCFM Papers,

251. See $1 \mathrm{~W}$. Winthrop, supra note 179, at 220; William C. De HaRT, ObServations on Military LaW, and the Constitution and Practice of Courts Martial 132 (1846 \& photo. reprint 1973 of 1859 printing).

252. 1 W. WINTHROP, supra note 179 , at 220 ; W. DE HART, supra note 251 , at 132.

253. See note 87 supra.

254. Mankato Rec., Nov. 15, 1862, at 2, col. 1.

255. See Letter from J. Adv. J. Morrison to Ass't Adj. Gen. Rollin Olin (Nov. 25, 1864), in Indian Prisoners, NARG 94 (Entry 173).

256. 1 W. WINTHROP, supra note 179 , at $266-70$. 
evidence... [had] been reported" to Lincoln. ${ }^{257}$ Reverend Thomas Williamson wrote that he had:

only read the testimony in four cases ... but am satisfied in my own mind from the slight evidence on which these are condemned that there are many others in that prison house who ought not to be there; and that the honor of our Gov[ernment] and the welfare of the people of Minnesota as well as that of the Indians requires a new trial before unprejudiced judges. ${ }^{258}$

Sibley vehemently defended the Commission, although in so doing he admitted to many of the weaknesses of the proceedings:

[I]t should be borne in mind that the Military Commission appointed by me were instructed only to satisfy themselves of the voluntary participation of the individual on trial, in the murders or massacres committed, either by his voluntary concession or by other evidence and then to proceed no further. The degree of guilt was not one of the objects to be attained, and indeed it would have been impossible to devote as much time in eliciting the details in each of so many hundred cases, as would have been required while the expedition was in the field. Every man who was condemned was sufficiently proven to be a voluntary participant, and no doubt exists in my mind that at least seven-eighths of those sentenced to be hung have been guilty of the most flagrant outrages, and many of them concerned in the violation of white women and the murder of children. ${ }^{259}$

In a letter to Bishop Whipple, Sibley likened the proceedings to a drum-head court-martial, a court-martial held in the field under the pressures of war, which is "not expected to enter into details of a technical character."260 But drum-head courts-martial-officially termed "garrison" or "regimental" courts-martial-are not authorized to try capital cases, or even to order imprisonment for more than one month, ${ }^{261}$ no doubt for the very reason that they are not able to grant full and fair trials under exigent circumstances.

\section{B. Commission Prejudice}

The potential for unfairness described above was compounded by the

257. Letter from Ass't Sec'y of the Interior John Usher to Brig. Gen. Henry Sibley (Dec. 10, 1862), in Letters Rec'd, NARG 393 (Entry 346).

258. Letter from Rev. Thomas Williamson to Rev. Stephen Riggs (Nov. 24, 1862), in Riggs Papers, MHS; see also Letter from Rev. Thomas Williamson to Rev. Stephen Riggs (Nov. 17, 1862), in Riggs Papers, MHS (asking Riggs to "look over" some of the testimony with General Pope "and point out to him its utter inconclusiveness"); Letter from Rev. Thomas Williamson to S.B. Treat (Nov. 21, 1862), in ABCFM Papers, MHS:

I doubt whether the whole state of Minnesota can furnish 12 men competent to sit as jurors

in their trial. . . . From our Governor down to the lowest rabble there is a general belief that all the prisoners are guilty, and demand that whether guilty or not they be put to death as a sacrifice to the souls of our murdered fellow citizens.

259. Letter from Brig. Gen. Henry Sibley to Ass't Sec'y of the Interior John Usher (Dec. 19, 1862), in Letters and Telegrams Sent, NARG 393 (Entry 343). As I describe below, see Part V infra, the evidence did not establish the charge that many were "concerned in the violation of white women and the murder of children." Perhaps Sibley referred not to the charges proved, but more generally to what he was sure the convicted had done during the war.

260. Letter from Brig. Gen. Henry Sibley to Bishop Henry Whipple (Dec. 7, 1862), in Whipple Papers, MHS.

261. Act of Apr. 10, 1806, ch. 20, $\S 1$, arts. 66, 67, 2 Stat. 359, 367. 
composition of the Commission itself. All members of the Commission were local residents, likely to react as vehemently as any other Minnesotan to the events of the war. The military commanders noted the strength of the soldiers' sympathy with the citizenry regarding the desire to punish the Da$\mathrm{kota}$; the officers feared that the soldiers would support an attempt by mob violence to accomplish what Lincoln might not be prepared to do. ${ }^{262}$ Reverend Thomas Williamson suggested: "[I]f the members of the court who try them think and feel as do a majority of those whom I hear speak of the Dakotas and the editorial corps of Minnesota[,] universally so far as I know[] innocence will be no guaranty of safety."263

The trials began immediately after hostilities ceased; they were held near the scene of the fighting while passions were most inflamed and fears remained of renewed fighting by the Dakota who had fled. The Commission members had themselves fought in the battles and thus had been under attack by the very individuals on whom they now passed judgment. ${ }^{264}$ It is inconceivable that they came to their task with open minds. William Marshall, who served on the Commission through the early trials, admitted as much, saying that "his mind was not in a condition to give the [ ] men a fair trial." 265 Reverend John Williamson described the trial proceedings by stating that each defendant was "first prejudged guilty of any charge ... the court ... [ [chose] to prefer against him and then if he denies he is cross examined with all the ingenuity of a modern lawyer to see if he cannot be detected in some error of statement."266 Reverend Riggs, who was present at many of the trials, wrote to the St. Paul Pioneer about the attitudes of the members of the Commission:

I have a very high regard for all the gentlemen who composed the military commission. I count them individually among my personal friends. But they were trying Indians; and my sense of right would lead me to give Indians as fair and full a trial as white men. This was the difference between us. ${ }^{267}$

262. See text accompanying note 110 supra.

263. Letter from Rev. Thomas Williamson to Rev. Stephen Riggs (Oct. 25, 1862), in Riggs Papers, MHS.

264. All five Commission members had been at the most recent Battle of Wood Lake, and three of them were at the attack at Birch Coulee, where loss of life on the American side had been particularly heavy. Approximately 200 Dakota soldiers surrounded the American encampment at Birch Coulee and kept it under siege for 31 hours until Colonel Sibley arrived with his troops. The Americans had used their bayonets to dig shallow trenches for protection and were without food and water during most of the siege. When Sibley arrived 'he found a 'sickening sight.' Thirteen men and no less than ninety horses lay dead, forty-seven men were severely wounded, and many more were less seriously hurt.... The stench of decaying bodies was overwhelming. The survivors were weak and exhausted ...." K. CARLEY, supra note 6, at 44 . Although military commissions were often composed of individuals who had more of a stake in the outcome of the trial than typical civilian jurors, the members were rarely as personally involved in the events leading to the charges being tried as were the Commission members here. See notes 297-303, 311-319, \& 324-334 infra and accompanying texts.

265. Letter from Bishop Henry Whipple to Ass't Sec'y of the Interior John Usher (Apr. 21, 1863), in Whipple Papers, MHS (quoting Marshall's statement). MHS.

266. Letter from Rev. John Williamson to S.B. Treat (Nov. 5, 1862), in ABCFM Papers,

267. St. Paul Pioneer, supra note 246. 
Isaac Heard, attempting to defend the Commission, admitted that he believed there was "[n]early universal complicity" in the war; in the absence of evidence of innocence, "the inference was very logical and natural, that the defendant being an Indian, with the sentiments, inclinations, attachment and revengeful impulses of an Indian, did not fall within the exception, but acted as the vast majority of the other Indians did."268

\section{Authority to Convene the Commission}

The composition of the Commission was thus problematic, but probably lawful. More serious difficulties are presented by Colonel Sibley's role in the proceedings. The statutes governing courts-martial-applicable by army order to military commissions as wel1269-suggest that Colonel Sibley did not, in fact, have authority to convene the Dakota trials.

I have already identified one difficulty in discussing the review of Wowinape's trial. ${ }^{270}$ Because the officer who convenes a court-martial is the first to review the proceedings for error, it is important that he be free from bias or the appearance of bias. Article of War 65 therefore expressly provided that an officer who was the "accuser" of an inferior officer could not himself convene the court-martial to try the junior officer. ${ }^{271}$ Both General Pope and Judge Advocate General Holt concluded that Sibley was the accuser in the Dakota trials, ${ }^{272}$ and Sibley did not disagree. Sibley himself noted that the Dakota were tried based on "charges and specifications preferred by" him. ${ }^{273}$ Article of War 65 therefore suggests that he should not also have acted to convene and subsequently review the proceedings. ${ }^{274}$

Sibley argued that article 65 should not be applied to military commission trials because it was designed solely to protect inferior officers from the prejudice their superiors might feel towards them. ${ }^{275}$ In a formalistic sense, Sibley was correct: By its express terms, article 65 only limited the authority of an officer to convene courts-martial to try his inferior officers. A literal

268. St. Paul Pioneer, Dec. 11, 1862, at 1, col. 4 (letter from "H."-presumably Isaac Heard. The writer identified himself as having been present at the trials and gave details similar to those published in I. HEARD, supra note 6).

269. Although the Articles of War in 1862 nowhere mentioned military commissions or the procedures to be followed in establishing them, the Army had determined, at least by January 1, 1862 , that military commissions were to be "ordered by the same authority, be constituted in a similar manner, and their proceedings be conducted according to the same general rules as courtsmartial, in order to prevent abuses which might otherwise arise." See, eg., Gen. Order No. 1, HQ, Dept. of the Missouri, Jan. 1, 1862, reprinted in 8 WAR OF THE REBELLION, SER. I, supra note 52, at 476. Similar orders were issued in other Departments. See 2 W. WINTHROP, supra note 179, at 74.

270. See text accompanying notes 175-183 supra.

271. $1 \mathrm{~W}$. WINTHROP, supra note 179 , at 68-69. As described earlier, the officer is an "accuser" if he either originates the charge or adopts and becomes responsible for it, unless he is acting solely in an official capacity by ordering an investigation after facts warranting such an investigation are brought to his attention.

272. See text accompanying notes 181-183 supra.

273. Letter from Brig. Gen. Henry Sibley to J. Adv. Gen. Joseph Holt (Dec. 7, 1863), in Sioux War Trials, MHS P1423.

274. 1 W. WINTHROP, supra note 179 , at 69 .

275. See text accompanying note 185 supra. 
reading of the statute would not prevent an officer from ordering and then reviewing courts-martial of enlisted men or military commission trials of enlisted men or civilians. In the absence of any statutes establishing procedures for military commissions, however, the military had already determined that a commission trial should be conducted in the same manner as a court-martial. ${ }^{276}$ As both General Pope and Judge Advocate General Holt agreed, the same potential for actual or perceived bias and prejudgment exists whenever an individual both prefers charges and reviews the outcome of a trial on those charges, whatever the tribunal may be called. ${ }^{277}$

The trials of the Dakota are a prime example of such bias and prejudgment. Sibley's correspondence, both before and after the trials, clearly shows that he had precisely the kind of bias that inspired the rule preventing him from playing both roles. On August 24, 1862, while still pursuing the Dakota, Sibley called them "the fiends, the devils in human shape! . . . [M]y heart is hardened against them beyond any touch of mercy."278 His communications with General Pope, quoted earlier, display his assumption that most of the Dakota men were implicated. ${ }^{279}$ Before reviewing any of the trials, Sibley had already told Pope that he would probably approve the results. ${ }^{280}$ As he wrote to Bishop Whipple in December 1862:

I approved the proceedings; because I had no reason to doubt the criminality of every man that has been condemned. On the contrary, I sent back many cases where men had been acquitted for lack of evidence for revision, and in several of these, additional testimony was adduced, and the Indians sentenced to be hung. 281

While Sibley might have permitted an acquittal where there was truly no evidence of participation, and he noted one instance in which he remitted a sentence because the evidence was inconclusive, ${ }^{282}$ a pattern of prejudice is

276. See note 269 supra.

277. In at least one other instance, in 1866, the Army agreed that article 65 should apply to trial by military commission. $1 \mathrm{~W}$. WINTHROP, supra note 179, at 67 n.3. Congress, too, thought that the same protection against bias or the appearance of bias should extend beyond inferior officers accused by their superiors. In 1884, Congress amended article 65 to forbid an officer from ordering a commission to try "any officer under his command." Act of July 5, 1884, ch. 224, 23 Stat. 121. In 1913, it was amended once again to forbid an officer to be both accuser and convener of a trial of any person. Act of Mar. 2, 1913, ch. 93, 37 Stat. 722.

278. Letter from Brig. Gen. Henry Sibley to Mrs. Henry Sibley (Aug. 24, 1862), in Sibley Papers, roll 11, frame 664, MHS [microfilm].

279. See text accompanying notes 74-76 supra; see also Letter from Brig. Gen. Henry Sibley to Mrs. Henry Sibley (Oct. 17, 1862), in Sibley Papers, roll 11, frame 674, MHS [microfilm] (describing the surrender of thirteen lodges and noting that there were "twenty two men, most of them desperate rascals who ... [ [would] be hung").

280. Letter from Brig. Gen. Henry Sibley to Maj. Gen. John Pope (Oct. 7, 1862), reprinted in 13 WAR OF THE REBELLION, SER. I, supra note 52, at 717.

281. Letter from Brig. Gen. Henry Sibley to Bishop Henry Whipple (Dec. 7, 1862), in Whipple Papers, MHS.

Sending the proceedings back for further testimony violated military procedures, see $1 \mathrm{~W}$. WINTHROP, supra note 179 , at 645 , as well as the fifth amendment prohibition against double jeopardy, U.S. CONST. amend. V.

282. See Letter from Brig. Gen. Henry Sibley to Bishop Henry Whipple (Dec. 7, 1862), in Whipple Papers, MHS. The case is that of the brother of Other Day. Sibley also displayed some sensitivity towards fairness and due process when he informed Lincoln that Tatimima had been 
clear. Although he claimed that "no one could have acted with a more conscientious regard to truth and justice ... in deciding the cases which were brought before me,"283 it is unlikely that his judgments could have remained unaffected by his own involvement in the war and in bringing the charges.

Practically, of course, the effect of any prejudgment by Sibley or the Commission members may have been attenuated by the subsequent review of the trials by individuals who were not accusers themselves. As the military itself determined in the case of Wowinape and in at least one other, unrelated trial, however, ${ }^{284}$ the appearance of impropriety alone was sufficient to warrant disapproval.

A second reason exists why Sibley may not have had proper authority to convene these commission trials. Under the Articles of War, only a general officer commanding an army or a colonel commanding a separate department could convene a general court-martial, which alone had the power to conduct trials for capital offenses. ${ }^{285}$ Sibley was not in charge of either an army or a separate department, but a district. At the end of 1861, Congress enacted a provision that permitted the commander of a division or a separate brigade to appoint a general court-martial in time of war, ${ }^{286}$ but Sibley's command was neither. ${ }^{287}$ Not until 1913 did Congress give the commander of a district the power to appoint general courts-martial, and then only "when empowered by the President."288

By the Army's own rulings, only those officers who were permitted by statute to convene a general court-martial had the authority to order a military commission that could issue death sentences. ${ }^{289}$ Indeed, in December 1861, General-in-Chief Halleck-in a letter to Brigadier General Pope, then in command of volunteers in the Mississippi Valley-declared null and void the proceedings of a military commission ordered by a colonel commanding a regiment on the express ground that only the General-in-Chief of the army or a general commanding a department had authority to order a military

convicted on incorrect testimony, see text accompanying note 128 supra, and when he supported pardons for a few of the convicted in the years following the executions, see text accompanying note 153 supra. Nonetheless, Sibley's correspondence and public statements leave the firm impression that he had largely prejudged the defendants.

283. Letter from Brig. Gen. Henry Sibley to Bishop Henry Whipple (Mar. 11, 1863), in Whipple Papers, MHS.

284. See 1 W. WINTHROP, supra note 179 , at 67 n.3.

285. Act of Apr. 10, 1806, ch. 20, art. 65, 2 Stat. 359, 367. Inferior officers commanding a regiment, corps, garrison, fort, or barracks could appoint a court-martial for non-capital offenses, but could impose at most a fine of one month's pay or imprisonment for one month. Id. arts. 66-67.

286. Act of Dec. $24,1861, \mathrm{ch} .3,12$ Stat. 330 . The Act provided that the general commanding the army in the field would have to confirm any death sentence. It further provided that if the division or brigade commander was the accuser or prosecutor, the next higher commander would convene the court-martial. Id.

287. See $1 \mathrm{~W}$. WINTHROP, supra note 179 , at 77-78 (officers sometimes erroneously convened courts-martial when their commands were not properly divisions or separate brigades; that "was peculiarly the case with the commands known as 'districts' ").

288. Act of Mar. 2, 1913, ch. 93, 37 Stat. 722.

289. See, e.g., Gen. Order No. 1, HQ, Dept. of the Missouri, Jan. 1, 1862, reprinted in 8 WAR OF THE REBELLION, SER. I, supra note 52, at 476. 
commission. ${ }^{290}$ Sibley himself expressed some doubts about whether he had authority to order the commissions, but nonetheless expected Pope to approve his acts afterwards. ${ }^{291}$

In August 1864, recognizing that district commanders like Sibley lacked authority to convene general courts-martial, the War Department granted permission to commanding officers of departments or armies to designate a district as a "separate brigade"; 292 since a brigade commander could order a general court-martial under the 1861 statute, ${ }^{293}$ such a designation would empower the district commander to do likewise. Two months later, just before Sibley convened the Commission to try Wakanozanzan and Shakopee, General Pope issued such an order, declaring the district of Minnesota, under Sibley's command, to be a separate brigade. ${ }^{294}$ As a brigade commander in 1864, Sibley could convene a commission under the 1861 amendment. As a district commander in 1862, he could not.

Again, these requirements serve only as technical objections to the trials. In reality, this limitation probably would not have changed the result since Pope-who wrote repeatedly to Sibley encouraging him to execute the guilty if not exterminate the whole tribe 295 _had the authority to order the trials anyway. If the reviewing authorities had disapproved the Dakota trials based on the failure to convene them properly, however, the resulting delay in punishment might have allowed some lessening of the anger and fear caused by the war. Renewed proceedings might then have been conducted more fairly and judiciously.

Moreover, the army's own record establishes precedent for sustaining such technical objections. The history of military commission trials of Confederate soldiers and Northern sympathizers during the same period suggests that the Dakota were not the only victims of the military's "rough justice." Throughout the Civil War, military commanders made many arrests, some for serious offenses, others for more frivolous acts or for simply speaking out against the war effort. Prisoners were often held without trial, a practice legitimized by President Lincoln's suspension of the writ of habeas corpus in September 1862.296

When military trials were held, the proceedings were marred by irregularities in trial procedure and overzealousness in prosecuting and sentencing. As with the Dakota trials, many of the Civil War military commissions

290. Letter from Gen.-in-Chief Henry Halleck to Brig. Gen. John Pope (Dec. 31, 1861), reprinted in 8 WAR OF THE REBELLION, SER. I, supra note 52, at 822; accord Gen. Order No. 1, HQ, Dept. of the Missouri, Jan. 1, 1862, reprinted in id. at 476.

291. Letter from Brig. Gen. Henry Sibley to Maj. Gen. John Pope (Sept. 28, 1862), reprinted in 13 WAR OF THE REBELLION, SER. I, supra note 52, at 687.

292. $1 \mathrm{~W}$. WINTHROP, supra note 179 , at 78.

293. See note 286 supra; and accompanying text.

294. Gen. Order No. 38, HQ, Dept. of the Northwest, Oct. 25, 1864, in Court Martial Cases, NARG 153, File NN3132.

295. See note 71 supra text accompanying note 60 supra.

296. See J.G. Randall, Constitutional Problems Under Lincoln 157-63 (1951). 
failed to follow mandated procedures, ${ }^{297}$ convicted on inadequate evidence, ${ }^{298}$ and ordered executions for acts not warranting such extreme punishment. ${ }^{299}$ Military justice during the war was criticized for its "looseness and inconsistency." 300 Contemporaneous military communications related to courts-martial and other military trials suggest that much of the irregularity can be attributed to ignorance of the system of military justice and to pressing responsibilities that distracted officers from remembering and applying the instructions issued from headquarters. No doubt the exigencies and passions of war also contributed.

Like the Dakota, then, many other individuals were ordered imprisoned or executed after deficient military trials. But when the defendant was a Confederate soldier or northern Confederate sympathizer, the President and the War Department often acted as a check on precipitous action by the commanders in the field, particularly as the war progressed and the proper procedures became better defined. Many proceedings-including death sentences-were disapproved for irregularities as minor as failing to administer the oath to the members of the commission or court-martial or failing to ask the defendant if he wished to challenge any members of the tribunal. ${ }^{301}$ Indeed, one such order of disapproval noted that "[i]n a proceeding involving life, such irregularities [as failing to read the convening order to the prisoner or present the charges to him in writing] are wholly inexcusable, and make the execution of the death sentence legally impossible." ${ }^{302}$ In

297. See, eg., Opinion of J. Adv. Gen. Joseph Holt to Pres. Abraham Lincoln (Sept. 26, 1862), in Letters Sent-JAG, NARG 153 (Entry 1) (sentence disapproved because judge advocate not sworn); Opinion of J. Adv. Gen. Joseph Holt to Maj. Gen. Benjamin Butler (Nov. 4, 1862), in id. (sentence disapproved because records forwarded to Judge Advocate General were copies only, not originals as required); Opinion of J. Adv. Gen. Joseph Holt to Maj. Gen. Benjamin Butler (Dec. 16, 1862), in id. (sentence disapproved because record did not show that prisoners were permitted to object to panel members or were read charges against them, or that witnesses were sworn, and because record did not contain cross-examination of witnesses); Gen. Order No. 255, Aug. 1, 1863, in id. (death sentence disapproved because record did not show that order convening Commission was read in presence of prisoner or that privilege of challenge was offered or that commission members were sworn); Gen. Order No. 151, May 26, 1863, in id. (death sentence disapproved because Commission and judge advocate not sworn on the record); Opinion of J. Adv. Gen. Joseph Holt to Brig. Gen. Arboth (Nov. 7, 1863), in id. (proceedings disapproved because phrase endorsed, "Respectfully forwarded," was not in conformity with regulation).

298. See, e.g., Gen. Order No. 346, Oct. 22, 1863, in Military Orders, NARG 94 (death sentence for alleged spy disapproved).

299. See, e.g., Gen. Order No. 135, May 18, 1863, in Military Orders, NARG 94 (execution ordered for aiding others to plunder and harboring stolen U.S. wagon, commuted to one year imprisonment; execution ordered for stealing horse from boy, commuted to six months imprisonment; execution ordered for aiding rebels to rob citizens, commuted to hard labor for duration of war; execution ordered for passing the lines dressed as a civilian and lurking near a fort, commuted to imprisonment for duration of war); Gen. Order No. 157, May 28, 1863, in Military Orders, NARG 94 (death sentence for associating with party in arms against U.S. government and violation of oath of allegiance; sentence commuted to one year imprisonment).

300. Military Courts, 5 U.S. SERV. MAG. 214, 214-17 (1866).

301. See note 297 supra.

302. Gen. Order No. 257, Aug. 1, 1863, in Military Orders, NARG 94; accord Opinion of J. Adv. Gen. Joseph Holt to Maj. Gen. Benjamin Butler (Dec. 16, 1862), in Letters Sent-JAG, NARG 153 (Entry 1) ("The record of all trials, especially when the punishment is death, should be full, complete and perfect."). 
many other cases the President reduced death penalties to terms of imprisonment ranging from six months to the duration of the war. ${ }^{303}$

The political situation facing Lincoln prevented him from responding in like fashion to the Dakota trials. Public outcry in Minnesota resulted in enormous pressure on the President to punish the Dakota for the war. No matter how the President might otherwise have reacted to the record laid before him, he apparently felt compelled to compromise by permitting a limited number of executions despite the unsatisfactory nature of the proceedings. ${ }^{304}$ In calmer times, would the reviewing authorities have recognized the procedural and substantive deficiencies and disapproved the results as they did in Civil War commission trials? The treatment of Wowinape supports this possibility. Pope's discovery of a "technical difficulty" barring confirmation of Wowinape's trial, a flaw that undermined all 326 convictions, suggests that the reviewing authorities recognized the weakness of the Commission proceedings and might have disapproved all of the Dakota trials, had that result seemed politically possible in December 1862 .

\section{MilitaRy COMMISSION AUTHORITY AND JURISDICTION}

In Part II, I described a number of deficiencies in the Dakota trial proceedings. The form of the trials-the use of a military commission to try American Indians for apparent acts of war-raises another, more fundamental question: Was a military commission a legitimate forum for the trials? In this Part, I trace the history of military commissions and their source of legal authority in an effort to answer that question.

\section{A. Statutory Provisions}

In 1862 , as today, there were three types of military tribunals. Courtsmartial were established by federal statute primarily to try soldiers, and civilians serving with the armed forces in the field, for offenses enumerated in the Articles of War, including striking an officer, failing to obey an order, and missing duty. ${ }^{305}$ In addition, the Articles authorized a court-martial of any person, whether soldier or civilian, charged with giving intelligence to, assisting, or harboring the enemy, ${ }^{306}$ and of any person charged with spying in time of war or rebellion. ${ }^{307}$ Courts of inquiry, also creatures of statutory

303. See note 299 supra.

304. See text accompanying notes $95-99$ supra.

305. The statutory provisions were contained in the Articles of War enacted in 1806. Act of Apr. 10, 1806, ch. 20, § 1, 2 Stat. 359. Between 1806 and December 1862, there were only 12 amendments to the Articles. See Frederick C. BRIGHTLY, ANALYTICAL Digest OF THE LAWS OF THE UNITED STATES, 1789-1857, at 83 (1858); Frederick C. BRightLy, ANALYTICAL Digest OF THE LAWS OF THE UNITED STATES, 1857-1863, at 1101-03 (1863). I discuss in the text all the amendments relevant to the questions raised here.

306. Article 56 made it an offense to "relieve the enemy with money, victuals, or ammunition, or [to] knowingly harbor or protect an enemy." Art. 56, 2 Stat. 359, 366 (1862). Article 57 established the offense of "holding correspondence with or giving intelligence to the enemy either directly or indirectly." Id. art. 57.

307. Act of Feb. 13, 1862, ch. 25, $\S 4,12$ Stat. 339, 340. The original Articles of War prohib- 
law, could be convened to collect information that might later be used in a court-martial proceeding or to explore allegations such as cowardice in battle. ${ }^{308}$

Determining the source of authority for the military commission, the type of military tribunal used in the Dakota trials, is more problematic. Until July 1862, the United States Congress had not recognized any form of military tribunal other than the court-martial and the court of inquiry. In the fall of 1862 , when most of the Dakota were tried, the only statutory reference to military commissions appeared in an off-hand reference about recordkeeping in a provision establishing the position of Judge Advocate General of the Army. ${ }^{309}$ In contrast to the very specific enumeration of offenses triable by court-martial, the statutory law provided no guidance regarding the validity and proper use of military commissions. As the Civil War progressed, Congress specifically authorized trial by military commission for various offenses, ${ }^{310}$ but in 1862 there was virtually no congressional recognition of that form of tribunal. Thus, although the military commission later evolved to become a statutorily authorized "war court," at the time of the Dakota trials it was simply an exercise of executive or military authority.

ited only spying "in time of war." $\$ 2,2$ Stat. 359, 371 (1862). The prohibition on spying during time of rebellion was added in February 1862, presumably to permit the military to try Confederates found spying within any part of the United States declared by the President to be in a state of insurrection. See 12 Stat. 339, 340.

308. See arts. 91-92, 2 Stat. 359, 370. Courts of inquiry could be used to "examine into the nature of any transaction, accusation or imputation against any officer or soldier." Id. art. 91, at 370. The statute provided that only the president or an accused could order a court of inquiry, as courts of inquiry could be "perverted to dishonourable purposes, and may be considered as engines of destruction to military merit, in the hands of weak and envious commandants." Id. art. 92, at 370. Since a court of inquiry did not sit in judgment of an accused, it required only a recorder "to reduce the proceedings and evidence to writing" rather than a judge advocate to act as prosecutor. See id. art. 91 , at 370 .

309. See Act of July 17, 1862, ch. 36, § 5, 12 Stat. 597, 598 ("the President shall appoint ... a judge advocate general ... . to whose office shall be returned, for revision, the records and proceedings of all courts-martial and military commissions, and where a record shall be kept of all procedings had thereupon").

310. See, e.g., Act of Mar. 3, 1863, ch. 75, $\S 30,12$ Stat. 731, 736 (murder, manslaughter, robbery, larceny, and certain other crimes, when committed by military persons in time of var or rebellion, punishable by court-martial or military commission); id. §38, 12 Stat. 737 (spies to be triable by military commission or court-martial); Act of July 4, 1864, ch. 253, § 6, 13 Stat. 394, 397 (civil officials of quartermaster department amenable to trial by military commission or court-martial for neglect of duty and fraud). In each of these statutes, Congress simply stated that cases triable by court-martial under statutory authority could also be tried by a military commission. Since military commissions and courts-martial were conducted in the same manner, see note 269 supra, there seems no basis for distinguishing the two forms of trial. In 1864, Congress enacted the first statute that specified trial by military commission for offenses not triable by court-martial. Act of July 2, 1864 , ch. $215, \S 1,13$ Stat. 356 (commanders of departments and armies authorized to execute sentences imposed by military commissions upon guerrillas for violation of the laws and customs of war). In the debate in the Senate preceding passage of the Act, however, Senator Lyman Trumbull, committee member and floor manager of the bill, repeatedly stated that the bill would not confer any new authority on military tribunals but would simply permit sentences of such tribunals to be carried out without the delay caused by having to seek presidential approval. CONG. GLOBE, 38th Cong., 1st Sess. 3030, 3416-17 (1864). 


\section{B. Military Commissions in the Mexican War}

Despite the absence of congressional authorization, the army began to use military commissions during the Mexican War as a way of conducting what the commanding officers viewed as necessary trials involving individuals and offenses not specified by statute as being subject to court-martial. In 1847, after invading central Mexico, General Winfield Scott declared martial law and issued General Order 20, announcing that certain crimes against soldiers committed by Mexican civilians-including murder, malicious stabbing, maiming, malicious assault and battery, robbery, and theft-would be subject to trial by military commission. ${ }^{311}$ General Scott also had some difficulty controlling his own troops but had authority under the Articles of War to try the soldiers only for enumerated offenses, most of them involving breaches of army discipline. ${ }^{312}$ General Order 20 therefore announced that the same crimes, if committed by his own soldiers against other soldiers or against civilians, would also be subject to trial by military commission. ${ }^{313}$

Pursuant to this declaration, Generals Scott, Wool, and Taylor convened military commissions to try soldiers and followers of the army for offenses such as theft, receiving stolen property, ${ }^{314}$ assault with a deadly weapon, ${ }^{315}$ and murder of a soldier. ${ }^{316}$ Military commissions were also ordered to try

311. Gen. Order No. 20, HQ Army at Tampico, Feb. 19, 1847, in Military Orders-Mexican War, NARG 94 (Entry 134). The complete list of offenses in the General Order was "[a]ssassination, murder, malicious stabbing, or maiming, rape, malicious assault and battery, robbery, theft, the wanton desecration of churches, cemeteries or other religious edifices and fixtures and the destruction except by order of a superior officer of public or private property." Id. Some of these offenses referred to acts committed not by civilians but by soldiers, who were also included in the order establishing military commissions. See text accompanying notes 313-316 infra.

312. On its face, Article of War 99 appears to provide ample authority to try soldiers for many acts not expressly made unlawful by the statute:

All crimes not capital, and all disorders and neglects which officers and soldiers may be guilty of, to the prejudice of good order and military discipline, though not mentioned in the foregoing articles of war, are to be taken cognizance of by a general or regimental court-martial, according to the nature and degree of the offence, and be punished at their discretion.

Act of Apr. 20, 1806, ch. 20, $\S 1$, art. 99, 2 Stat. 359, 371. In practice, however, the army had not viewed this provision as a grant of authority to try soldiers for acts such as rape, murder, robbery, arson, and assault with intent to kill. See Caldwell v. Parker, 252 U.S. 376, 381-83 (1920). Congress later remedied this problem by providing for military trial for such offenses by soldiers. Act of Mar. 3,1863 , ch. 75, § 30,12 Stat. 731, 736.

313. Gen. Order No. 20, HQ Army at Tampico, Feb. 19, 1847, in Military Orders-Mexican War, NARG 94 (Entry 134). In fact, individuals brought before these commissions were sometimes tried for offenses not expressly included in the list enumerated in General Order 20. For example, the orders convening military commissions listed such offenses as burglary, picking pockets, carrying a concealed weapon, riotous conduct, and attempting to pass counterfeit money, none of which were contained in General Order 20. 1 W. WINTHROP, supra note 179, at 59-60.

314. Order No. 5, Mar. 13, 1848, in Military Orders-Mexican War (Puebla), NARG 94 (Entry 134); Order No. 36, May 21, 1848, in id; Order No. 176, June 14, 1847, in Military Orders-Mexican War (Gen. Scott), NARG 94 (Entry 134). 134).

315. Order No. 5, Mar. 13, 1848, in Military Orders-Mexican War (Puebla), NARG 94 (Entry

316. Gen. Order No. 97, Apr. 7, 1847, in Military Orders-Mexican War (Gen. Scott), NARG 94 (Entry 134). 
Mexican citizens for offenses such as theft $\mathrm{f}^{317}$ and selling liquor to soldiers. ${ }^{318}$ These instances were the first in which the army convened tribunals actually called "military commissions." Military commissions were used in a similar manner during the Civil War to provide a system of justice following the capture of rebel territory. 319

In essence, these military commissions replaced the civilian criminal courts in occupied, hostile territory after the declaration of martial law. ${ }^{320}$ The Supreme Court in 1857 confirmed that the President had the authority to establish such tribunals, ${ }^{321}$ but lower courts held that trial by these military commissions could continue only while military necessity demanded it and only during actual hostilities.322 At the time of the United States-Dakota War, martial law was declared only for the day on which the executions took place. Although tensions still ran high in September when the trials began, and both the settlers and the military feared renewed hostilities if the fleeing Dakota returned, actual fighting had ceased. Those Dakota who had not surrendered had fled. Moreover, although the settlements in Minnesota

317. Order No. 30, HQ Dept. of Puebla, May 17, 1848, in Military Orders-Mexican War (Puebla), NARG 94 (Entry 134); Order No. 33, HQ Dept. of Puebla, May 19, 1848, in id.

318. Order No. 17, HQ Dept. of Puebla, May 3, 1848, in Military Orders-Mexican War (Puebla), NARG 94 (Entry 134).

319. See, e.g., J. RANDALI, supra note 296, at 91 (martial law declared in New Orleans; William Mumford convicted and hanged for treason for tearing down United States flag after liberation of city).

320. See H.W. Halleck, INTERnational Law 782 (1861); see also S. Bent́t, A Treatise on Miltary LAW AND THE Practice of CourTS-MARTIAL 10-16 (4th ed. 1864). Halleck notes that in California, also the scene of fighting in the Mexican War, such offenses were generally tried in the civil courts; the occupying army set up special tribunals in only a few cases. H. HALLECE, supra, at 783.

321. Leitensdorfer v. Webb, 61 U.S. (20 How.) 176, $177-78$ (1857); accord Mechanics' \& Traders' Bank v. Union Bank, 89 U.S. (22 Wall.) 276, $295-97$ (1874); The Grapeshot, 76 U.S. (9 Wall.) 129, 132-33 (1869); Cross v. Harrison, 57 U.S. (16 How.) 164, 189-90 (1853). But see Jecker v. Montgomery, 54 U.S. (13 How.) 498, 515 (1851) ("neither the President nor any military officer can establish a court in a conquered country, and authorize it to decide upon the rights of the United States, or of individuals in prize cases, nor to administer the laws of nations"; the courts established in Mexico by the military commanders were "nothing more than agents of the military power, to assist it in preserving order in the conquered territory").

322. Several lower federal courts rejected the use of martial law in the period following the end of hostilities in the Civil War, granting writs of habeas corpus to release prisoners held under military authority. See, e.g., In re Egan, 8 F. Cas. 367 (C.C.N.D.N.Y. 1866) (No. 4303) (civilian tried for murder in South Carolina seven months after the rebel army surrendered); United States v. Commandant of Ft. Delaware, 25 F. Cas. 590 (C.C.D. Del. 1866) (No. 14,842) (four civilians tried for murder of military guard after hostilities had ceased). The Egan court suggested that martial law is really no law at all but simply the commanding officer's will, which takes the place of law that cannot be enforced under the conditions of war. The court found that martial law could be indulged only as a matter of necessity; when order is restored, that necessity ceases and the exercise of martial law is inappropriate.

Whether the military could continue to try civilians once order was restored was the subject of challenges to the use of military government under the Reconstruction Acts, but was never definitively decided. Congress first sought to block the Supreme Court's consideration of the question by removing the Court's appellate jurisdiction over habeas petitions. See Ex parte McCardle, 74 U.S. (7 Wall.) 506 (1868). When the Court decided that it nonetheless had jurisdiction, Ex parte Yerger, 75 U.S. (8 Wall.) 85 (1868), the prisoner was released before the merits of the question were reached. See ERWIN CHEMERINSKY, FEDERAI JURISDICTION 154-57 (1989) (discussing factual backgrounds of $\mathrm{McCardle}$ and Yerger). 
were in turbulence as a result of the fighting, the civil authority in the state was never interrupted. Nothing prevented access to the state courts, where trials for murder and other ordinary criminal charges would usually be held. Indeed, Governor Ramsey threatened to try the Dakota in the Minnesota courts if the army did not carry out what he saw as its responsibility to punish the offenders. ${ }^{323}$ The situation does not seem to have demanded summary military action, so the claim of military necessity could not have provided the army with the authority to try the Dakota by military commission for civilian crimes.

Another type of tribunal used by General Scott during the Mexican War provides a more apt historical model for the military commissions convened by Colonel Sibley to try the Dakota. These tribunals, called "councils of war," were court-martial-like bodies constituted to try individuals, not for criminal offenses committed in time of war, but for violations of the "laws of war"-emerging standards regarding proper conduct of warfare. ${ }^{324}$ Some commissions tried Mexican citizens or soldiers for encouraging desertion by United States soldiers; 325 others tried individuals for being "guerilleros."326 To the extent that any of the Dakota committed acts that could be considered violations of the laws of war, the tribunals established by General Scott might be historical precedent for trying the Dakota by military commission. ${ }^{327}$

323. Of course, the Dakota might have fared even worse in the state courts. Sibley may have been motivated to convene a commission in order to ensure fairer trials than would have occurred in the state courts. See text accompanying notes 490-494 infra. Similar motives may have led to the trial of the Lincoln murder conspirators before a military commission rather than before a civil jury. See Thomas R. Turner, What Type of Trialt A Civil Versus a Military Trial for the Lincoln Assassination Conspirators, in 4 PAPERs OF the ABRAfiam Lincoln Assoclation 29, 38 (1982). Nonetheless, as explained in the text, jurisdiction for such a commission trial was lacking and no tribunal, state or federal, could legitimately try the Dakota for anything other than violating the laws of war.

324. See Gen. Order No. 181, HQ Army at Puebla, June 19, 1847, in Military Orders-Mexican War (Gen. Scott), NARG 94 (Entry 134). In his treatise, Winthrop lists eight orders, 2 W. WINTHROP, supra note 179, at $60 \mathrm{n} .1$, but some of these are simply orders creating a council, rather than records of judgments by the councils. See, e.g., Gen. Order No. 181, June 19, 1847, in Military Orders-Mexican War (Gen. Scott), NARG 94 (Entry 134); Gen. Order No. 184, June 24, 1847, in id.

325. See Gen. Order No. 187, HQ Army at Puebla, June 24, 1847, in Military Orders-Mexican War (Gen. Scott), NARG 94 (Entry 134).

326. See Gen. Order No. 372, HQ of the Army, Dec. 12, 1847, in Military Orders-Mexican War (Volunteer Div.), NARG 94 (Entry 134). The Order referred to "atrocious bands called Guerilleros and Rancheros who under instructions from the late Mexican Government or authorities, continue to violate every rule of warfare observed by civilized nations." It provided that no quarter should be given to such individuals and that a Council of War should be convened to try any such offenders "falling into the hands of American troops." The Council could condemn a prisoner to death for "flagrant" violations of the laws of war "on satisfactory proof that such a prisoner, at the time of capture actually belonged to any party or group of known robbers or murderers or had actually committed murder or robbery upon any American officer or soldier or follower of the American Army." Unfortunately, the army records remaining from the Mexican War are not complete, and there were no further orders describing individual trials for the described offenses. It is thus not possible to learn what the army considered to be "murder" or a "flagrant" violation of the laws of war.

327. Several commentators have pointed to other earlier trials-the 1780 trials of Major John André and Joshua Hett Snith for conspiring with Benedict Arnold and the 1815 trial of Louis Louaillier for assisting the enemy-as predecessors to the military commission trial. See 2 W. WINTHROP, supra note 179, at 59; A. Wigfall Green, The Military Commission, 42 AM. J. INT'L L. 832, 


\section{Military Commissions in the Civil War}

During the Civil War, the use of military commissions greatly expanded. In addition to their use as part of military government in occupied rebel territory, they were employed, much like General Scott's "councils of war," to try Confederate soldiers accused of violating the laws of war. ${ }^{328}$ Soldiers were tried for offenses such as robbing civilians, ${ }^{329}$ passing Union lines in civilian dress, ${ }^{330}$ and boarding a United States ship in neutral territory with intent to seize it on the high seas. ${ }^{331}$

Military commissions were also widely used in northern states and occupied rebel territory to try individuals accused of "disloyal practices," 332 including fighting as guerrillas, often by attacking civilians. ${ }^{333}$ General Order 100, which was issued in April 1863 to instruct the military about proper conduct in warfare, formalized the role of military commissions for trying violations of the laws of war, declaring that "cases which do not come within the Rules and Articles of War, or the jurisdiction conferred by statute on courts-martial, are tried by military commissions" under the common law of war. ${ }^{334}$

Whether any of these military commission trials was lawfully conducted is less than clear, however. Statutory authority remained meager, ${ }^{335}$ and questions were repeatedly raised regarding the military's authority to conduct trials not affirmatively authorized by Congress. Indeed, shortly before the United States-Dakota War, the highest ranking judicial officer in the Army, Judge Advocate John F. Lee, suggested to the Secretary of War that

832-33 (1948). In each of these cases, however, the defendants were tried for offenses defined by statute as triable by court-martial. Thus the trials do not truly represent the use of military commissions.

328. Interestingly, Confederate soldiers were treated as legitimate belligerents despite the United States government's refusal to recognize the Confederacy as an independent sovereign. Although the United States maintained that it could try the rebels for treason, it chose to grant the Confederate forces the privilege of being treated as belligerents, both for humanitarian reasons and to avoid retaliation against Union troops. See J. RANDALI, supra note 296, at 65-69.

329. Gen. Order No. 135, May 18, 1863, in Military Orders, NARG 94; Gen. Order No. 151, May 26,1863 , in id.

330. Gen. Order No. 135, May 18, 1863, in Military Orders, NARG 94.

331. 8 U.S. DEPARTMENT OF WAR, THE WAR OF THE REBELlion: A COMPILATION OF THE OFFICIAL RECORDS OF THE UNION AND CONFEDERATE ARMIES, SERIES II, 674-81 (1899) [hereinafter WAR OF THE REBELIION, SER. II].

332. J. RANDALL, supra note 296, at 175-76.

333. See Gen. Order No. 135, May 18, 1863, in Military Orders, NARG 94; Gen. Order No. 267, Aug. 3, 1863, in id.; Gen. Order No. 151, May 26, 1863, in id. Most, if not all, of the trials for conducting guerrilla warfare occurred in occupied rebel territory, where many individuals not in the Confederate army nevertheless engaged in obstructive tactics and acts of violence. J. RANDALI, supra note 296 , at $174-75$.

334. Gen. Order No. 100, I1 13, Apr. 24, 1863, reprinted in Richard SHElly HARTiGAN, LIEBER's CODE AND THE LAW OF WAR 45 (1983) [hereinafter Gen. Order No. 100]; accord Letter from Maj. Gen. Henry Halleck to Brig. Gen. John Pope (Dec. 31, 1861), reprinted in 8 WAR OF THE REBELIION, SER. I, supra note 52, at 822-23 (prisoners of war who violate the laws of var are to be tried by military commission, not court-martial; source of law is "general code of war," not Articles of War, and charge should be "violation of the laws of war").

335. See notes 309-310 supra. 
military commissions had no legitimacy, ${ }^{336}$ although Lee later acquiesced to the practice despite his continuing doubts. ${ }^{337}$

Lee's successor, former Secretary of War Joseph Holt, ${ }^{338}$ was less ambivalent. As of September 8,1862, the issue was still under advisement by the President, but Holt expressed his own view that "[ $t]$ hese 'commissions' . . . have existed too long in the service, and [are] too essential to its wants and emergencies, to be now ignored. Long and uninterrupted usage has made them as it were part and parcel of the common military law." 339 Despite the lack of formal authority, President Lincoln concurred. On September 24, 1862 , he declared that rebels, insurgents, and all persons "guilty of any disloyal practice affording aid and comfort to rebels" would be subject to martial law and liable to trial by court-martial or military commission. ${ }^{340}$

\section{Military Commissions After the Civil War}

The legitimacy of wartime commissions was settled only temporarily, as shown by the numerous challenges to the practice that arose once wartime tension abated. In 1865 , for example, controversy arose concerning the validity of the military commission appointed to try the defendants charged with the assassination of President Lincoln. ${ }^{341}$ Both defense counsel and the Judge Advocate presented lengthy arguments to the Commission concerning the legality of that body. ${ }^{342}$ During the trial, the Attorney General advised

336. Letter from J. Adv. John Lee to Sec'y of War (Mar. 1862), in Letters Sent-JAG, NARG 153 (Entry 1), at 289 ("[U]nder our municipal laws, State or Federal, these procedings [a military commission trial of a civilian] are of no validity. Military commissions are not a tribunal known to our laws; and military commanders have no power to inflict death except by sentence of courtmartial.").

337. Letter from J. Adv. John Lee to Sec'y of War (June 8, 1862), in Letters Sent-JAG, NARG 153 (Entry 1), at 312 ("I have been compelled to submit my opinion that these 'military commissions' within the territory and jurisdiction of the U.S. are tribunals unknown to our laws, and there is no warrant of law for executing the sentences of death they adjudge. Still it is done.").

338. Holt's title was Judge Advocate General, a post newly created by Congress in the Act of July 17,1862 , ch. 201, § 5, 12 Stat. 597, 598, but his role was identical to Lee's.

339. Letter from J. Adv. Gen. Joseph Holt to Sec'y of War Edwin Stanton (Sept. 8, 1862), in Letters Sent-JAG, NARG 153 (Entry 1). As discussed above, see notes 311-319, 324-327 supra and accompanying texts, this "long usage" dated back only to the Mexican War in 1846-1847, and was used mostly in occupied territory to allow trial for normal criminal offenses that otherwise would have gone unpunished.

340. Proclamation by the President, Sept. 24, 1862, reprinted in 6 JAMES D. RICHARDson, Messages aNd PAPERS OF THE PResidents 1789-1897, at 98-99 (1897).

341. See generally Turner, supra note 323.

342. Reverdy Johnson, attorney for Mary Surratt, argued that the Bill of Rights protected the defendant, a citizen of the United States, and assured her trial by jury and presentment to a grand jury, unless she was serving in the armed forces. He denied that the President had authority under his "war power" to order such trials, because the war power belonged to Congress and Congress had not made statutory provision for military commissions. REVERDY JOHNSON, AN ARGUMENT TO Establish the ILlegality of Military COMMISSIONS IN THE UNTTED STATES 7-10, 14-16 (1865) (available at University of Minnesota Law Library). In response, Special Judge Advocate John Bingham made an argument notable less for clarity than for his repeated harangues about the evils of the enemies of the Union and the arrogance of those who would challenge the authority of the President and his Commission. See, e.g., John Bingham, Trial of the Conspirators For THE ASSASSINATION OF PRESIDENT LincolN 4-6, 12-13, 14-15 (1865) (available at University of Minnesota Law Library). He suggested that the Commission could have no authority to rule on the 
President Johnson that the military tribunal was validly conducted under the law of nations as an incident of war; the Constitution, he said, made the law of nations part of the laws of the land by granting Congress the power to "define and punish piracies and felonies committed on the high seas, and offences against the laws of nations." 343 Even if Congress did not deine such offenses by statute, the Attorney General suggested, the military could act directly under the laws and usages of war, because the law of nations exists independently of any "definition" by Congress. ${ }^{344}$ The Commission apparently agreed; it convicted the defendants and sentenced them to death. No court was asked to review that conclusion.

The next prominent discussion about the validity of military commissions arose in the trial of Confederate soldier Henry Wirz in August 1865. Wirz was charged and ultimately convicted of abusive treatment and murder of Union soldiers at the Andersonville prisoner of war camp in Georgia. ${ }^{345}$ He objected to the jurisdiction of the tribunal as one "unauthorized by either statute, military law, martial law, or well-established usage."346 As in the Lincoln assassination trial, the Judge Advocate argued that the power to conduct this military trial arose from the necessity for and right of any sovereign to protect itself in times of war and rebellion. ${ }^{347}$ The Commission implicitly concurred and overruled the challenge to its jurisdiction. ${ }^{348}$ Again, no court decision followed. Indeed, despite the large number of military commission trials of Confederate soldiers, none of these cases reached the federal courts for any definitive ruling on the validity of the trials, perhaps in large part because the President had suspended the writ of habeas corpus for the insurgents. ${ }^{349}$

The writ of habeas corpus was also suspended for citizens of Union states convicted by military commissions, ${ }^{350}$ but a case challenging such a trial

question of its own validity, because if it ruled the Commission invalid it would be in the absurd position of deciding a question it found it had no authority to decide. Id. at 7-11. On the substantive question of the source of authority for the tribunal, he supported the use of the military tribunal to try the alleged Lincoln assassins as an exercise of martial law and a necessary power of any government to defend itself. Id. at 13-14, 21-50.

343. 11 Op. Att'y Gen. 297, 299 (1865) (quoting U.S. ConsT. art. I, § 8, cl. 10).

344. Id. at 300,310 . The Attorney General responded to Reverdy Johnson's arguments that the fifth and sixth amendments required that the defendants be indicted by grand jury and tried by petit jury by distinguishing between "crimes," which fell under the protection of those amendments, and "offences," which did not. Id. at 312-13.

345. Trial of Henry Wirz, reprinted in H.R. ExEc. Doc. No. 23, 40th Cong., 2d Sess. 1 (1868).

346. Id. at 10.

347. Id. at 726-28.

348. Id. at 805,809 .

349. See Proclamation by the President, supra note 340. At least one state court had previously addressed questions about the validity of military trials of civilians in time of war. Smith v. Shaw, 12 Johns. 257 (N.Y. 1815). Shaw brought an action for assault and battery and false imprisonment based on his arrest and detention by the military. Shaw had been charged with, among other things, exciting insurrection and being a spy. Chief Judge Thompson, speaking for the New York Supreme Court, readily found that, because he was an American citizen, Shaw could not be charged as a spy. Therefore, he could not be brought before a court-martial for trial. Id. at 265.

350. See Proclamation by the President, supra note 340. Despite the suspension of the writ, many federal district courts entertained petitions for writs of habeas corpus and demanded responses from the military. If they responded at all, the military commanders simply relied upon the Presi- 
finally reached the United States Supreme Court in $1866 .{ }^{351}$ In Ex parte Milligan, ${ }^{352}$ the Court rejected the notion that, because of the existence of martial law, the "laws and usages of war" permitted the military to try the civilian defendant; the Court concluded that no jurisdiction existed for the trial. ${ }^{353}$ The Court emphasized, however, that Milligan was a citizen of a loyal state in which the civil courts were still in operation and concluded that, whatever authority the military might have under other circumstances, it could not try civilians in this manner. ${ }^{354}$ The Court did not reach-indeed it expressly declined to discuss-the question of "what rule a military commander . . . can impose on states in rebellion to . . quell the insurrection," 355 or how the result would change if the defendant had been a prisoner of war "engaged in legal acts of hostility against the government."356

\section{E. The Modern View}

As discussed in the previous section, there was no indication how the courts at the time of the Dakota trials would have ruled on the validity of military commissions used to try prisoners-of-war. In 1942, the Supreme Court in Ex parte Quirin ${ }^{357}$ finally held that the Army could conduct military commission trials of foreign nationals accused of sabotage, espionage, and other acts in violation of the laws of war, but by that time Congress had specifically authorized commission trials for violations of the laws of war. ${ }^{358}$

dent's suspension of the privilege. See J. RANDALL, supra note 296, at 157-63. A few courts upheld the authority of the military to make the arrests. See, e.g., Ex parte Vallandigham, 28 F. Cas. 874, 924 (C.C.S.D. Ohio 1863) (No. 16,816), cert. denied, 68 U.S. (1 Wall.) 243 (1863); Ex parte Field, 9 F. Cas. 1,8 (C.C.D. Vt. 1862) (No. 4761). Other courts determined the arrests to be unlawful and issued writs of habeas corpus, but the commanders were under orders not to obey the writs and the courts had no ability to enforce their judgments. See J. RaNDALI, supra note 296, at 157-63. Some judges issued opinions denouncing the failure to obey the court. See, eg., Ex parte Merryman, 17 F. Cas. 144 (C.C.D. Md. 1861) (No. 9487). At least one judge simply acknowledged the difficult position of the marshal who held the prisoner, caught between two masters, and declined to hold him in contempt. Ex parte Benedict, 3 F. Cas. 159, 173-74 (C.C.N.D.N.Y. 1862) (No. 1292).

351. Ex parte Milligan, 71 U.S. (4 Wall.) 2 (1866). The Court was earlier presented with the opportunity to rule on the validity of military commission trials of citizens of the Union in Ex parte Vallandigham, 68 U.S. (1 Wall.) 243 (1863). Perhaps uncomfortable with the possibility of undermining the President's war effort, the Court declined to decide the question whether the military commission had jurisdiction over Vallandigham. The Court ruled instead that neither the United States Constitution nor federal statutes granted the Supreme Court appellate jurisdiction to review military trials by writ of certiorari. Id. at 251-52. Although Vallandigham had sought a writ of habeas corpus from the United States Circuit Court, which was denied, he apparently petitioned the Supreme Court for a writ of certiorari to review the military proceedings rather than to review the denial of habeas corpus relief. See J. RaNDALI, supra note 296, at 178-79. In Ex parte Milligan, the defendant instead sought review of the denial of the writ of habeas corpus, and the Court agreed that there was jurisdiction to hear the claim. See text accompanying notes 352-356 infra.

352. 71 U.S. (4 Wall.) 2 (1866).

353. Id. at $121,130$.

354. Id. at 121-27.

355. Id. at 126.

356. Id. at 131 .

357. 317 U.S. 1 (1942).

358. Id. at 28-29. The primary statutory authorization was contained in the 1920 revision of the Articles of War. Act of June 4, 1920, ch. 227, 41 Stat. 759. Article 12 specified that general 
The Court expressly declined to answer whether the President as Commander-in-Chief could, without congressional approval, constitutionally create military commissions and authorize them to try foreign nationals for war crimes. 359

Thus, no court has ever precisely addressed the question whether military commissions, constituted in the absence of legislative authority, are legitimate tribunals for considering violations of the laws of war. Congress certainly could have specified that such offenses be punished: the Constitution gives Congress the power to "define and punish ... Offences against the Law of Nations," 360 which includes the laws of war. Moreover, if Congress, by statute, made criminal certain actions violating the laws of war, Congress could also have authorized the military to conduct trials for offenses arising under the statute. Indeed, in Ex parte Quirin the Supreme Court accepted the notion that Congress could simply authorize the military to punish violations of the "laws of war" without specifying the precise contours of those laws. The Court allowed Congress to leave the definition of offenses under the laws of war to "the system of common law applied by military tribunals so far as it should be recognized and deemed applicable by the courts." 361

The difficult question is whether the military could have operated directly under the law of nations, with no statutory authority of any kind. The Supreme Court stated in 1855 that, even without Congressional action, the law of nations, including the laws of war, forms a part of "the municipal jurisprudence of every country" in its dealings with foreign countries and their nationals. ${ }^{362}$ The Court emphasized that this was particularly true dur-

courts-martial would have the power to try "any other person [not subject to the Articles of War] who by the law of war is subject to trial by military tribunals." Id. at 789. Article 15 specified that the Articles of War "shall not be construed as depriving military commissions . . of concurrent jurisdiction in respect of offenders or offenses that by statute or by the law of war may be triable by such military commissions." Id. at 790. Congress thus did not expressly define the jurisdiction of military commissions but instead recognized the law of war as providing a separate source of authority for military tribunals.

359. 317 U.S. at 29.

360. U.S. CoNST. art. I, \& 8, cl. 10.

361. 317 U.S. at 29-30. The Quirin Court relied upon earlier decisions that had established the flexibility accorded Congress in defining offenses against the law of nations. See Harmony v. United States, 43 U.S. (2 How.) 210, 232 (1844); The Marianna Flora, 24 U.S. (11 Wheat.) 1, $40-41$ (1826); United States v. Smith, 18 U.S. (5 Wheat.) 153, 158-62 (1820). In 1867, perhaps in response to protests about the military arrests and trials during the Civil War or to civil suits against the officers who had made those arrests, Congress attempted to validate the actions of the military after the fact:

[A]11 acts, proclamations, and orders of the President [from March 4, 1861 to July 1, 1866]

... respecting martial law, military trials by courts-martial or military commissions, or the arrest, imprisonment and trial of persons charged with participation in the late rebellion against the United States ... and all proceedings and acts done or had by courts-martial or military commissions ... are hereby approved in all respects, legalized and made valid ....

Act of Mar. 2, 1867, ch. 155, 14 Stat. 432. To the extent that this Act attempted to make punishable acts that were not otherwise unlawful at the time, it was condemned as an ex post facto law. See In re Murphy, 17 F. Cas. 1030, 1032 (C.C.D. Mo. 1867) (No. 9947). Under the ruling in Murphy, if the military commission trying the Dakota went beyond its authority, the Act of Mar. 2, 1867, could not legitimize those trials.

362. Jecker v. Montgomery, 59 U.S. (18 How.) 110, 112 (1855). See also cases cited in note 321 supra. 
ing a state of war. ${ }^{363}$ Moreover, throughout the early history of America, statesmen and judges repeatedly asserted that the law of nations was part of domestic law. ${ }^{364}$ Such statements could lead to the conclusion that the military indeed possessed the power to act directly under the law of nations. But the judicial pronouncements were made largely in the context of issuing grand jury charges, not upholding prosecutions. ${ }^{365}$ When the question whether criminal prosecutions could be maintained directly under customary law was presented to the Supreme Court in 1812 in United States y. Hudson, ${ }^{366}$ the Court held that federal courts had no such common law jurisdiction. ${ }^{367} \mathrm{~A}$ broad reading of that case suggests that crimes not established by statute-such as crimes against the law of nations-were not punishable. 368

Thus substantial uncertainty exists whether, in 1862, the courts would have recognized the military's power to exercise common law authority to punish foreign nationals for violations of the laws of war. It is clear, however, that many of those who considered the question of the legitimacy of the military commissions at the time of the Civil War answered it in the negative. ${ }^{369}$

\section{SOVEREIGNTY AND WARFARE}

I suggestad in Part III that if the Dakota were simply individuals creating mayhem, a military commission was not a legitimate form of trial because martial law had not been declared and civilian authorities could have tried the Dakota under the state's criminal laws. If, on the other hand, the Dakota were foreign nationals fighting a war against the United States, there was at least historical precedent for the trials, though doubts remained about the validity of any military commission proceeding. In this Part, I explore the legitimate scope of trials of foreign nationals fighting a war, concluding that the law of nations permits such prosecutions only for offenses against the laws of war. I then consider whether the Dakota were acting as mem-

363. Jecker, 59 U.S. at 112.

364. See generally Stewart Jay, The Status of the Law of Nations in Early American Law, 42 VAND. L. REV. 819, 825-26 (1989).

365. Id. at 825-26.

366. 11 U.S. 31,7 Cranch 32 (1812).

367. Id. at 34.

368. Hudson may be a more limited decision, however. One commentator has suggested that the case was a product of concerns about protecting the lawmaking power of the states, not a statement about the applicability of the law of nations. Jay, supra note 364, at 843-44; see also Stewart Jay, Origins of Federal Common Law (pt. 1), 133 U. PA. L. REv. 1003, 1012-19 (1985). But see Arthur M. Weisburd, The Executive Branch and International Law, 41 VAND. L. REv. 1205, 122223 (1988) (Hudson "obviously weakened the authority of those Framers who contended . . . that the laws of the United States included the law of nations").

369. Realistically, it seems unlikely that the courts would have invalidated the trials on this ground. While legally the state courts had no jurisdiction, see Part IV infra, and military tribunals' claim to jurisdiction was debatable, the highly charged racial atmosphere and the nature of the attacks made some punishment of the Dakota virtually inevitable. As a practical matter, the best alternative may have been fairly conducted military trials for violations of the laws of war, but the Dakota were not even afforded that. 
bers of a sovereign nation at war with the United States, and thus entitled to the protection of international law for actions committed in wartime.

\section{A. The Laws of War in 1862}

It was well accepted in 1862 , as it is today, that when two sovereign nations wage war against one another, the soldiers on both sides are entitled to different treatment than individuals who engage in similar acts of assault, murder, and destruction not authorized by a nation at war. In a declared war between two sovereign powers, the law of nations permitted the use of force as a proper means of obtaining a nation's objectives. ${ }^{370}$ Captured enemy soldiers were therefore not to be punished for the killing and destruction carried out in the war effort, but were to be treated as lawful belligerents and held as prisoners of war.

This protection of enemy soldiers extended only to certain actions, however. Although the standards were not well developed, the law of nations in 1862 considered some acts of violence too odious to be permitted in modern warfare. These acts included assassination, poisoning, killing an enemy who had surrendered, and killing unarmed civilians. ${ }^{371}$ Such actions were considered punishable violations of the laws of war. Moreover, foreign citizens who killed or plundered without a formal or informal commission from their sovereign were considered bandits or marauders, subject to punishment for their depredations. ${ }^{372}$

This practice of treating enemy soldiers as justified in fighting a war, but limiting by custom those acts considered lawful in warfare, developed as a means to control the extent of killing and destruction caused by war. ${ }^{373}$ Treating the enemy's soldiers as prisoners of war rather than as criminals helped to ensure reciprocal leniency from the enemy; requiring authorization

370. See H. Halleck, supra note 320, at 425-26; De VATTEL, The LaW of Nations, bk. 3 , $\S \S 1-5,136$ (J. Chitty ed. 1852); Gen. Order No. 100, supra note 334 (Instructions for the Government of Armies of the United States in the Field, also known as the Lieber Code, see text accompanying notes 377-380 infra). See generally PERCy BoRDWELL, THE LAW of WAR BETWEeN Belligerents (1908); The LAW OF WAR (R. Miller ed. 1975); Hugo Grotius, THE RightS OF WAR AND PEACE (A. Campbell trans. 1901); Restraints on WAR (M. Howard ed. 1979); Roda Mushkat, Who May Wage War? An Examination of an Old/New Question, 2 AM. U.J. INT'L L. \& PoL'y 97 (1987). The modern law of nations now grants belligerent status to groups other than nation states. Organized groups subject to some form of military discipline, but not owing allegiance to a nation state, are now also accorded the rights of a lawful belligerent. INGRED DETTER DE LUPIS, THE LAW OF WAR 23-24 (1987); Mushkat, supra, at 104-37. Even in 1862 an entity that was not a fully sovereign state might, in practice, become a lawful belligerent if it actually went to war, though the theory recognized only sovereign states as having the legal right to wage war. Mushkat, supra, at 100 . In determining the proper treatment of the Dakota, I have relied upon the terminology and concepts generally in use in 1862 .

371. H. HALLECK, supra note 320, at 398-404, 426-28; DE VATTEL, supra note 370, bk. 3, $\$ \S 140-147,173$. However, some of these otherwise forbidden acts might be justified under certain circumstances. See H. HALLECK, supra note 320, at 428-29, 439-40, 444-45; DE VATTEL, supra note 370 , bk. 3, §§ 141-142, 145, 151. 226.

372. H. HALlECK, supra note 320 , at $386-87$; DE VATTEL, supra note 370 , bk. 3 , $\S \S 66-68$,

373. I.D. DE LUPIS, supra note 370 , at $124-25$. 
from a sovereign prevented individuals from taking advantage of wartime instability to kill or plunder for private purposes.

Most articulations of the rules regarding treatment of belligerents appeared in treatises by acknowledged experts in international law, ${ }^{374}$ not in domestic case law. As early as 1609, however, English law recognized that an alien enemy taken in war was not subject to the common law of the realm. ${ }^{375}$ Few cases arose to test that concept in the American courts, but in 1878 the United States Supreme Court confirmed in Coleman v. Tennessee that soldiers were not amenable to the ordinary criminal law of the enemy. ${ }^{376}$

Perhaps the most significant expression of United States concurrence in the international rules of warfare was the adoption of "Instructions for the Government of Armies of the United States in the Field," also known as the Lieber Code, by United States Army General Order in April 1863. ${ }^{377}$ Called one of the "three great landmarks of our modern Law of War," it was the first attempt anywhere to codify the customary law of war and establish legal standards under domestic law for the operation of national armies. ${ }^{378}$ The Lieber Code recognized each of the principles already outlined regarding the legitimacy of violence in wartime. ${ }^{379}$

Although the Lieber Code was not adopted until several months after the United States-Dakota War, the code reflected an understanding of the nature of warfare widely shared in the United States and other Western countries. ${ }^{380}$ Thus, to determine whether the United States complied with its own as well as international standards of wartime behavior, the treatment of the Dakota in 1862 should be judged in accordance with these norms. If the Dakota were a sovereign people and fought as a nation at war, the Dakota prisoners should have been punished only if they violated the laws of war. ${ }^{381}$ In the remainder of this Part, I discuss whether the Dakota were sovereign and acted in a sovereign capacity, which would entitle them to such limited

374. See sources cited in note 370 supra.

375. Calvin's Case, 77 Eng. Rep. 377, 398 (1609).

376. 97 U.S. 509, 515-16, 519 (1878). When the death sentence imposed on a Union soldier by a court-martial during the Civil War had not been carried out nine years later, the State of Tennessee tried and convicted him on the same charge. The Court reversed the state conviction, holding that, as a soldier in the Army of the United States, the defendant could not be tried under the ordinary criminal laws of the enemy (Tennessee).

The only contrary ruling appeared in the case of Government v. M'Gregory, 14 Mass. 498 (1780). In $M^{\prime}$ 'Gregory nine individuals were indicted for murder; they challenged the jurisdiction of the court on the grounds that they were prisoners of war and subjects of the King of Great Britain and therefore triable only under the law of nations in courts-martial, not under "municipal law." The court upheld the Massachusetts Attorney General's contention that the prisoners could be tried by the state for offenses malum in se and overruled the jurisdictional challenge. Id. at 499.

377. Gen. Order No. 100 , supra note 334 , at 45 . Francis Lieber, a scholar in international law and a close friend of General Halleck, was instrumental in developing General Order 100.

378. Geoffrey Best, Restraints on War By Land Before 1945, in RESTRAINTS ON WAR, supra note 370 , at 20.

379. See Gen. Order No. 100 , supra note 334 , at $45-51$.

380. See R. HARTIGAN, supra note 334, at 14-15; notes 370-376 supra and accompanying text.

381. See note 370 supra and accompanying text. 
immunity. In Part V, I consider whether the acts of particular Dakota were nonetheless punishable as violations of the laws of war.

\section{B. Sovereignty of the Dakota}

The first question is whether the Dakota were a sovereign people capable of declaring war on the United States. The Dakota had no doubt about their own sovereign status and their consequent right to declare and fight a war: The Dakota community lived separate from the Americans, maintained its traditional governing structure, and dealt with the United States as a foreign government through the tribe's own designated leaders. What I explore in detail here is whether the United States was compelled to recognize Dakota sovereignty by the history of its relations with the Indian nations and by international and domestic law.

\section{Indian warfare and sovereignty in United States history.}

The treatment of Indian tribes in wartime over the course of United States history demonstrates a consistent recognition of the sovereignty of Indian nations and their right to wage war. ${ }^{382}$ When groups of Indians fought in what the Americans perceived as a unified force-when the fighting was widespread and appeared to be motivated by a group decisionneither the military nor the civilian authorities of the United States formally held enemy individuals responsible for ordinary acts of destruction committed as part of the fighting. 383 When prisoners were taken by the Americans, those captured were usually held until peace was restored and then were released, imprisoned, or moved to reservations according to the peace terms agreed upon or imposed. ${ }^{384}$ Occasionally military commanders took it upon themselves to punish the Indian war leaders summarily-frequently by hanging them without further ceremony-but these incidents seem to represent individual action more than governmental policy. ${ }^{385}$ Thus, although the fighting men from Indian nations sometimes suffered retaliation for their ac-

382. Throughout this discussion I refer to historical incidents both before and after 1862 . While the latter are not "precedent" for the events of 1862 , they shed light on the attitudes and actions of the earlier period, particularly because of the consistency of treatment demonstrated, with the notable exception of the trials and executions that are the focus here.

383. Indeed, in only one instance did the Americans formally hold individuals responsible for the killing of civilians or other acts of destruction that violated the laws of war. This exception was the 1873 trial of Kintpuash (Captain Jack) for violating a flag of truce. See text accompanying notes 387-388 infra.

384. See, e.g., Robert M. Utley \& Wilcomb E. Washburn, The AMerican Heritage HISTORY OF THE INDIAN WARS 145-46 (1977) (General Sidney Jessup seized Osceola, leader of the Seminole resistance, and imprisoned him until his death); id. at 150 (Black Hawk jailed for a year); id. at 237-39 (72 Cheyenne, Kiowa, Arapaho, and Comanche war leaders deported and imprisoned for three years at Fort Marion, an old Spanish fortress at St. Augustin, Florida); id. at 298 (after Chief Joseph and the Nez Percé surrendered, they were moved to a new reservation); id. at 270 (those captured in Bannock-Paiute War sent to reservations); id. at 329 (Goyahkla (Geronimo) and his fighting men sent to prison forts in Florida and Alabama following surrender).

385. For example, in 1858, Colonel George Wright summarily hanged 15 members of various tribes involved in a successful attack on the troops commanded by Lieutenant Colonel Edward Steptoe. R. UTLEY \& W. WASHBURN, supra note 384, at 204-05. And in early 1863, as reported by a 
tions in war, never before or after the United States-Dakota War were they condemned by any form of legal process for violence associated with warfare.

Indeed, in one instance in 1879 , this limited immunity was made explicit. In that incident, seven bands of Utes residing on a reservation in western Colorado and eastern Utah fought a week-long battle with a detachment of United States soldiers at Milk Creek, on the reservation. When peace was restored, a civilian commission of inquiry was formed to determine whether to punish individual Utes. The commission cleared those who fought at Milk Creek because they were warriors engaged in a fair fight. ${ }^{386}$ Similarly, in California in 1873, a group of Modocs engaged in battles with U.S. soldiers and killed some civilians living in the vicinity of the fighting. Apparently no attempt was made to punish individually the majority of those who fought, including those who attacked civilians. Three of the Modocs, however, had killed two American soldiers sent to negotiate under a flag of truce. The Attorney General ruled that these three individuals could be tried for violating the laws of war. ${ }^{387} \mathrm{He}$ noted that the Indian tribes had been recognized as independent communities for treaty-making purposes and that they frequently carried on "organized and protracted wars"; he concluded that the Modocs, therefore, were subject to the rules of warfare and could be punished for transgressing them. ${ }^{388}$ Presumably, as recognized in a Judge Advocate General's opinion several years later, the members of an Indian tribe could not be held responsible if they did not violate the rules of war. ${ }^{389}$

\section{The law of Indian sovereignty in 1862 .}

While the extensive historical record reflects a consistent de facto recognition that the members of an Indian tribe should be treated as legitimate belligerents in wartime, the legal record on this issue is sparse. Only one case has ever directly addressed the question whether an American Indian group had sufficient sovereignty to afford its captured soldiers prisoner-of-war status. ${ }^{390}$ As the unexplained and unsupported decision of a territorial trial court, however, the case is singularly unenlightening. ${ }^{391}$ The only other judi-

prospector who witnessed the incident, soldiers guarding Mangas Coloradas, chief of the Warm Springs tribe, tortured him with heated bayonets and then shot him when he protested. Id. at 226.

386. Dee Brown, Bury My Heart at Wounded KneE 388 (1970). The Commission named 12 Utes to stand trial for killing Nathan Meeker, the much-resented Indian agent, and nine other employees at the Agency. R. UTLEY \& W. WASHBURN, supra note 384, at 310. The Commission thus seemed to be drawing a distinction between those who fought "fairly" and those who violated the laws of war.

387. 14 Op. Att'y Gen. 249, 253 (1873).

388. Id.

389. See Letter from J. Adv. Gen. Joseph Holt to Adj. Gen. (Jan. 29, 1875), in Letters SentJAG, NARG 153 (Entry 1); text accompanying note 434 infra.

390. United States v. Cha-to-kah-na-pe-sha, 25 F. Cas. 414 (Super. Ct. Ark. Terr. 1824) (No. 14,789a).

391. Id. In this 1824 case, the Superior Court of the Territory of Arkansas tried an Osage for murder. The defendant claimed that the Osage were sovereign and had the right to declare war and that, consequently, his actions-not described in the opinion - were acts of war. Abruptly and without reference to any authority, the court noted that "[e]ven if this position was sound, which is not 
cial references to the status of Indian nations at war with the United States appear as dicta in general discussions of the nature of Indian sovereignty, primarily in nineteenth century Supreme Court decisions that still serve as the foundation for present-day concepts of Indian sovereignty.

The first such direct reference was in 1831 in Cherokee Nation v. Georgia, ${ }^{392}$ in which Chief Justice Marshall first described Indian tribes as "domestic dependent nations."393 Although he determined that the Cherokees were not a "foreign state" for purposes of article III jurisdiction, Marshall described the Cherokees as "a distinct political society, separated from others, capable of managing its own affairs and governing itself."394 By its treaties with the Cherokees, Marshall said, the United States had recognized them "as a people capable of maintaining the relations of peace and war, of being responsible in their political character ... for any aggression committed on the citizens of the United States, by any individual of their community."395 Marshall's notion of "domestic dependent" status meant that the Indian nations had placed themselves under the protection of the United States and could no longer carry on foreign relations directly with any other nation. A majority of the Court recognized that the Indian nations nonetheless retained control over "the relations of peace and war," at least with respect to the United States. ${ }^{396}$

The next year, in Worcester $v$. Georgia, ${ }^{397}$ Marshall again recognized that

the fact," the Osage were not at war with the United States and had disavowed the defendant's actions and surrendered him to the authorities for prosecution. The court thus held that the Osage nation could not claim belligerent status based on sovereignty and that, in any event, this Osage certainly could not because his nation was not at war. Even if the facts had warranted a more extended consideration of the question whether the Osage had a right to wage war, this alternative holding by a territorial trial court could hardly be considered strong precedent on the issue.

392. 30 U.S. (5 Pet.) 1 (1831).

393. Id. at 17 .

394. Id. at 16, 19. Article III of the United States Constitution grants the federal courts jurisdiction over "Controversies ... between a State, or the Citizens thereof, and foreign States, Citizens or Subjects." U.S. CoNST. art. III, § 2. In Cherokee Nation, the Cherokees sought an injunction to prevent the state of Georgia from enforcing the laws of Georgia within Cherokee territory; these laws had the alleged purpose of annihilating the Cherokes as a political society and seizing the Cherokee lands. 30 U.S. (5 Pet.) at 15.

395. 30 U.S. (5 Pet.) at 16.

396. Justice McLean joined Chief Justice Marshall. Justices Thompson and Story, in dissent, agreed that the Cherokees were sovereign and suggested further that they were a foreign state under the Constitution. Id. at 52-62 (Thompson, J., dissenting). Although it did not expressly refer to the power to wage war, the dissent's view of Cherokee sovereignty necessarily encompassed that power. Justices Johnson and Baldwin, while concurring with the Court's result, denied that the Cherokee were sovereign. Id. at 21-27 (Johnson, J., concurring); id. at 33-39 (Baldwin, J., concurring). Justice Duvall apparently did not participate. See Joseph C. Burke, The Cherokee Cases: A Study in Law, Politics, and Morality, 21 STAN. L. REv. 500, 517-18 (1969). Thus, four of the seven justices agreed that the Cherokees had the right to wage war. Marshall indirectly recognized the same point earlier in Johnson v. McIntosh, 21 U.S. (8 Wheat.) 543 (1823). By recognizing that a land cession in a peace treaty between the United States and the Illinois and Piankeshaw nations could effectively annul an earlier grant of the land to an individual, Marshall implicitly recognized the Illinois and Piankeshav as nations capable of making war and settling terms of peace.

397. 31 U.S. (6 Pet.) 515 (1832). The State of Georgia had convicted Samuel Worcester of residing in Cherokee territory without a license required under Georgia statutes. The Supreme Court reversed the conviction, holding that the Cherokee nation was a "distinct community" in which the laws of Georgia had no force. Id. at 561-63. 
the English, and by implication the Americans, had regarded the Indian nations "as nations capable of maintaining the relations of peace and war."398 Justice McLean, concurring, made the point more explicit:

We have recognized in them the right to make war. No one has ever supposed that the Indians could commit treason against the United States. We have punished them for their violation of treaties; but we have inflicted the punishment on them as a nation, and not on individual offenders among them as traitors. ${ }^{399}$

Both of these cases echoed an 1828 opinion of the Attorney General about the status of the Creeks: "Like all other independent nations, they have the absolute power of war and peace." 400

Because the Supreme Court never had to decide directly whether an Indian nation was legitimately at war with the United States for purposes of the law of nations, all of these statements are dicta, not holdings. Nonetheless, when one considers the nature of sovereignty that Chief Justice Marshall acknowledged for the Cherokees, it follows that they did have the power to wage war and the right to have their soldiers treated as belligerents under the laws of war. Marshall most fully expressed his idea of Indian sovereignty in Worcester. ${ }^{401}$ There he wrote that the Indian tribes had always been treated as independent by the European nations and subsequently by the United States, and that the lands received from the Indians had been purchased as from another sovereign. ${ }^{402}$ When the Cherokees placed themselves under the protection of the British or the Americans, it was not an abandonment of their sovereignty, but instead an alliance. ${ }^{403}$ The Cherokees may have been a dependent ally, weaker than the United States and seeking support and protection, but the relation "was that of a nation claiming and receiving the protection of one more powerful; not that of individuals abandoning their national character, and submitting, as subjects, to the laws of a master." 404 The settled doctrine of the law of nations, Marshall noted, is that the "weaker power does not surrender its independence . . . by associating

\section{Id. at 548.}

399. Id. at 583 (McLean, J., concurring).

400. 2 Op. Att'y Gen. 110, 133 (1828). The same point was made sixty years later, after many more wars with the Indian nations, by the United States Court of Claims:

The principles of international law have been applied to hostilities with the Indian tribes so far as to accord to them the rights of a belligerent. It is too well-settled to need citations that an Indian warrior in a war waged within the boundaries of a State can not be tried for murder or robbery in its courts .... When war comes, it becomes lawful to kill, capture, and destroy; and if by the peculiar circumstances of a case such acts are deemed offenses, it is because they are offenses against the laws of war.

Love v. United States, 29 Ct. Cl. 332, 346 (1894); accord Leighton v. United States, 29 Ct. Cl. 288, 304, 325 (1894); Ke-tuc-e-mun-guah v. McClure, 122 Ind. 541, 23 N.E. 1080 (1889).

401. 31 U.S. (6 Pet.) at 515.

402. Id. at 546-47; see also Steven Paul McSloy, American Indians and the Constitution: An Argument for Nationhood, 14 AM. INDIAN L. REv. 139, 139-40 (1989) (Marshall articulated the view, accepted by European monarchs and legal scholars throughout the colonial period, that the Indian nations of North America were independent sovereign powers.).

403. 31 U.S. (6 Pet.) at 555.

404. Id. 
with a stronger, and taking its protection."405 The law of nations recognizes that even a tributary state, so long as it retains the right to govern its own body, retains its sovereign status. ${ }^{406}$ Moreover, once considered sovereign, a nation acquires and retains the power, under the law of nations, to declare and fight wars, ${ }^{407}$ with no distinction made for wars against a protector state or for those fought after recitation of treaty obligations to maintain perpetual peace and friendship.

Marshall's belief that the Cherokees maintained their existence as a nation, though perhaps not "foreign" for purposes of article III, was based on his review of the history of Cherokee relations with Europeans and Americans. Beginning with the assumption that the Cherokees were sovereign before Europeans arrived on the North American continent, Marshall considered the treaties between the Cherokees and other nations and determined that the treaty language continued to recognize the sovereignty, if not the separateness, of the Cherokees. 408

A review of the treaties between the Dakota and the United States suggests that these treaties similarly recognized the sovereign status of the $\mathrm{Da}$ kota. For example, in the Treaty of 1805 the "Sioux Nation" granted land to the United States and expressly granted "full sovereignty and power over said districts forever," a recognition that the "Sioux" were a "nation" that had the power to grant sovereignty along with territory. ${ }^{409}$ Subsequent treaties proclaimed "perpetual peace and friendship" between the United States and the tribes or bands signing the treaty, 410 an earmark of international agreements. ${ }^{411}$ Felix Cohen, an authoritative scholar of Indian law ${ }^{412}$ suggested that treaty provisions related to war and peace, national boundaries, and extradition show the international status of the Indian tribes. ${ }^{413}$ Each of these kinds of clauses appears in the treaties with the Dakota. For example, the 1825 treaty was an effort "to promote peace among [the Sioux and other tribes] and to establish boundaries among them"; 414 it spoke of drawing lines

405. Id. at 561.

406. See DE VATTEL, supra note 370 , bk. $1, \S 7$.

407. See id. at bk. $2, \S \S 49-52$, bk. $3, \S \S 1-5$.

408. See Worcester v. Georgia, 31 U.S. (6 Pet.) 515, 552-57 (1832); Cherokee Nation v. Georgia, 30 U.S. (5 Pet.) 1, 16 (1831).

409. Treaty with the Sioux, Sept. 23, 1805, art. 1, reprinted in 2 CHARLES J. KAPPLER, INDIAN AfFairs: LAwS AND Treaties 1031 (19C4). The Treaty of 1805 was confirmed by the Senate on April 16, 1808, 2 J. Exec. Proc. S. 80 (1808), but was apparently never proclaimed by the President or published in the United States Statutes at Large. 2 C. KAPPLER, supra, at 1031 n.

410. Treaty with the Sioux of the Lakes, July 19, 1815, art. 2, 7 Stat. 126, 126 (1846); Treaty with the Sioux-See-see-toan and Wah-pe-toan Bands, July 23, 1851, art. 1, 10 Stat. 949,949 (1855); Treaty with the Sioux-Med-ay-wa-kan-toan and Wah-pay-koo-tay Bands, Aug. 5, 1851, art. 1, 10 Stat. 954, 954 (1855).

411. See Love v. United States, 29 Ct. Cl. 332, 340-41 (1894); Feldx S. Cohen's HandBooz OF FEDERAL INDIAN LAw 39 (1942) [hereinafter CoHEN's HANDBOOK].

412. The courts have viewed Cohen's work as authoritative. See, e.g., Squire v. Capoeman, 351 U.S. 1, 8-9 (1956); Felix Frankfurter, Foreword to FeliX S. Cohen, THE LEgal Conscience: SELECTEd PAPERS OF Felix S. Cohen at xiii (1960); Stephen M. Feldman, Felix S. Cohen and His Jurisprudence: Reflections on Federal Indian Law, 35 BufFalo L. REv. 479, 514-17 (1986).

413. CoHEN's HANDBOOK, supra note 411, at 39.

414. Treaty with the Sioux and Chippewa, Sacs and Fox, Menominie, Ioway, Sioux, Winne- 
"dividing [the] respective countries" of the tribes. ${ }^{415}$ The 1858 treaties contained pledges "not to engage in hostilities with the Indians of any other tribe unless in self-defence" and to deliver to the United States any member of their bands who became an offender against the laws of the United States or of Minnesota. 416

The Dakota treaties departed significantly from those reviewed by Marshall in Worcester 417 only in their handling of the land reserved to the Dakota. It appears in Worcester that the Cherokees never ceded to the United States the land recognized as Cherokee territory by the treaties but simply retained it as their own. ${ }^{418}$ The 1851 treaty with the Dakota, on the other hand, seemed to cede land to the United States, which then returned some of it to the Dakota. ${ }^{419}$ Since a sovereign state can acquire its domain by grant or cession, as well as by long occupancy, discovery, or conquest, ${ }^{420}$ the Dakota would have been no less sovereign had they received their land by treaty from the United States rather than by retaining it. Certainly the Dakota had no cause to believe that the treaty terms changed their sovereign status; indeed, they probably were unaware of the technical provisions for transferring the land reserved to them. Nor is there any indication that the Americans thought the 1851 treaties affected the status of the Dakota. In fact, seven years later the Americans concluded another set of treaties with the Dakota, indicating a continuing understanding that the Dakota remained sovereign. ${ }^{421}$

\section{Although Chief Justice Marshall's concept of Indian sovereignty thus}

bago, and a portion of the Ottowa, Chippewa, and Potawattomie Tribes, Aug. 19, 1825, preamble, 7 Stat. 272, 272 (1846).

415. Id. arts. 2 \& 5, 7 Stat. 272-73.

416. Treaty with the Sioux-Mendawakanton and Wahpakoota Bands, June 19, 1858, art. 6, 12 Stat. 1031, 1033-34 (1863); Treaty with the Sioux-Sisseeton and Wahpaton Bands, June 19, 1858, art. 6, 12 Stat. 1037, 1039 (1863).

417. Worcester v. Georgia, 31 U.S. (6 Pet.) 515 (1832).

418. Id. at 552-57.

419. The 1851 treaties negotiated with the Mdewakanton, Wahpekute, Sisseton, and Wahpeton bands appear to provide for a total cession of all Dakota lands in the Territories of Minnesota and Iowa. In return, the United States agreed to set apart specified land on the Minnesota River "for the future occupancy and home of the Dakota Indians, ... to be held by them, as Indian lands are held." Treaty with the Sioux-Sisseeton and Wahpaton Bands, July 23, 1851, art. 3, 10 Stat. 949, 949; Treaty with the Sioux-Med-ay-wa-kan-toan and Wah-pay-koo-tay Bands, art. 3, 10 Stat. 954. The Dakota, however, understood the treaty to reserve for them the land on the Minnesota River without cession. In negotiating both treaties, Dakota leaders expressed concern that the terms might be changed in Washington. Minnesota Territorial Governor Alexander Ramsey and Commissioner of Indian Affairs Luke Lea assured them that no changes would be made. Ten months after the signing of the treaty, the Senate rejected its provisions and proposed instead that the president be permitted to set aside for the Dakota unspecified land outside the ceded territory. S. Res., 10 Stat. 957 (1852). Some chiefs refused to sign the amended treaties. One who refused to sign-Mazasha (Red Iron)-was arrested and the American negotiators replaced him with a chief more willing to comply. See I. HEARD, supra note 6, at 34-40; R. MEYER, supra note 6, at 86. Having little choice, the Dakota finally acquiesced to the amendments. See 10 Stat. 958 (1852). The President ultimately chose the precise tract of land specified in the original treaty terms. See generally R. MEYER, supra note 6, at 85-87 (discussing the above sequence of events).

420. H. HALLECK, supra note 320 , at 126; DE VATTEL, supre note $370, \mathrm{bk} .2, \S 80$.

421. Treaty with the Sioux-Mendawakanton and Wahpakoota Bands, 12 Stat. 1301; Treaty with the Sioux-Sisseeton and Wahpaton Bands, 12. Stat. 1037. 
encompassed the right to wage war, his was not the only theory offered by the Supreme Court before 1862. In 1846 in United States v. Rogers, ${ }^{422}$ Chief Justice Taney provided his own interpretation of the history of relations with the Indian nations, one totally at odds with the opinions of Chief Justice Marshall. Rogers raised the question whether a white American could renounce his citizenship, be adopted into the Cherokee nation, and thereafter be governed solely by Cherokee law rather than by American criminal law. In his opinion for the Court, Taney stated that the Europeans never treated or acknowledged the native tribes as independent nations but rather treated them as subject to the dominion and control of whichever European nation claimed, on the basis of discovery, the territory in which the Indian nation resided. Without citation to authority of any kind and without mention of the contrasting vision of history described in Cherokee Nation v. Georgia and Worcester, Taney wrote: "[W] think it too firmly and clearly established to admit of dispute, that the Indian tribes residing within the territorial limits of the United States are subject to its authority ...."423 If Taney meant, as it appears, that the Cherokees retained no aspects of sovereignty, then presumably they also had no right to wage war.

Subsequent commentators have severely criticized the Rogers opinion as a misreading of history and a misinterpretation of prior doctrine. ${ }^{424}$ In 1856, only ten years after Rogers, Taney contradicted his own earlier view when he stated, in Dred Scott v. Sandford: ${ }^{425}$

[T] he Indian[s] . . . were yet a free and independent people, associated together in nations or tribes, and governed by their own laws .... These Indian Governments were regarded and treated as foreign Governments, as much so as if an ocean had separated the red man from the white ... and the people who compose these Indian political communities have always been treated as foreigners not living under our Government. 426

The Court reconfirmed this position in 1884 in Elk $v$. Wilkins, ${ }^{427}$ holding that a person born as a member of and owing allegiance to an Indian tribe was no more the subject of the United States government than were children of subjects of any foreign government born within the United States. ${ }^{428}$ Whatever force Rogers might have had was dissipated by Taney's apparent abuse of the historical record, his own equivocation, and the Court's subsequent rejection of the view expressed in that case.

422. 45 U.S. (4 How.) 567 (1846).

423. Id. at 572 .

424. See, e.g., Milner S. Ball, Constitution, Court, Indian Tribes, 1 AM. B. Found. REs. J. 1, 40-42 (1987); Robert T. Coulter, $A$ History of Indian Jurisdiction, in RETHINKING INDIAN LAws 9 (1982); Nell Jessup Newton, Federal Power Over Indians: Its Sources, Scope, and Limitations, 132 U. PA. L. Rev. 195, 210 (1984); Daniel L. Rotenburg, American Indian Tribal Death $\rightarrow$ A Centennial Remembrance, 41 U. MiamI L. REV. 409, 420 (1986); Rachel San Kronowitz, Joanne Lichtman, Steven Paul McSloy \& Matthew G. Olsen, Toward Consent and Cooperation: Reconsidering the Political Status of Indian Nations, 22 HARV. C.R.-C.L. L. REV. 507, 524 (1987) (student authors).

425. 60 U.S. (19 How.) 393 (1856).

426. Id. at 403-04.

427. 112 U.S. 94 (1884).

428. Id. at 102. 
The prevailing and most persuasive Supreme Court theory of Indian sovereignty thus offers a conceptual affirmation of the manner in which the American Indian was ordinarily treated in wartime. Certainly, the United States throughout its history often trampled upon or ignored Indian sovereignty-for example, with respect to land claims and treaty rights. ${ }^{429}$ Nonetheless, the United States seemed to recognize, both in its actions and in its words, that the Indians were sufficiently separate and independent to retain the right, under the law of nations, to fight as sovereign nations and to have their members accorded the rights of lawful belligerents.

\section{Fighting as a Nation}

As noted earlier, the law of nations in 1862 recognized a distinction between violence committed as part of a public war and violent acts committed without such authorization or sanction. ${ }^{430}$ In a public war, those who fought were considered justified when they killed or destroyed within the bounds of "proper" warfare. In contrast, individuals who acted for their own private gain or who acted without authorization from their government, even if their government was at war, were considered marauders, robbers, and murderers and could be punished as such. The history of warfare between the United States and the Indian nations also reflects this distinction: While Indians who fought in wars were not punished as criminals for their acts, individual Indians were sometimes tried and punished-in criminal proceedings in state courts-if their actions seemed more like isolated attacks on individuals than part of official hostilities.431

In 1847, for example, Chief Tilokaikt, Tomahas, and several other Cayuses entered the Christian mission at Waiilatpu in Oregon Territory and killed fourteen people, including missionaries Marcus and Narcissa Whitman. The Cayuses apparently did not participate in any further fighting but simply faded into the countryside. Later, five of the "ringleaders" of the attack were tried and convicted for murder after they gave themselves up in 1850.432 Similarly, in 1871, Kiowa chiefs Satanta and Big Tree were tried for killing individuals during an attack on a wagon train that was part of a pattern of raids conducted from their base on the Kiowa reservation in Texas. ${ }^{433}$

In most of these instances, the distinction between individual acts and group warfare was not articulated. On some occasions, however, the difference was made explicit. In early 1875, for example, the Judge Advocate

429. See generally D. Brown, supra note 386; HeLEN HuNT JACKSON, A CENTURY of DisHONOR (1881 and photo. reprint 1965); VINE DELORIA, JR. \& Clifford M. LYTLE, AMERICAN INDIANS, AMERICAN JUSTICE (1983).

430. See text accompanying notes $370-372$ supra.

431. The courts, as well, have occasionally noted this distinction between individual acts and group warfare. See Montoya v. United States, 180 U.S. 261, 266 (1901); People v. McLeod, 25 Wend. 483, 578 (N.Y. Sup. Ct. 1841).

432. R. UTLEY \& W. WAShBURN, supra note 384 , at 179-81.

433. The two were condemned to death, but their sentences were commuted to imprisonment and, in 1873, they were freed to return to their people. Id. at 261-62. 
General ruled that a group of Indians accused of murder, robbery, and theft could be tried in state court because the alleged acts had occurred when there was no state of war. In doing so, the Judge Advocate General distinguished an earlier case in which "an entire Indian clan, having a tribal organization, engaged in hostilities, as such, against the United States."434

The United States, then, recognized the difference between acts of warfare and acts of individuals. The next step is to determine whether the Dakota acted as individuals or as a nation at war. Under the law of nations in 1862 , the manner in which a nation could declare war and thereby transform acts of individuals into acts of warfare was controlled by that nation's own fundamental law allocating decisionmaking responsibility. ${ }^{435}$ The Dakota nation, like many other Indian nations, was governed by consensus operating at levels ranging from a single band to the whole nation. ${ }^{436}$ Important decisions affecting the band as a whole were made at Council, a meeting of the men and sometimes also the women of the band. Generally, all who came to Council had an opportunity to speak, and the band took action only when there was sufficient agreement. Each band had the independence to reach its own governing decisions, including whether to go to war.

A decision as important, and with such ramifications, as a declaration of war, however, was often made at a Council attended by representatives of more than one band. A decision would still be made by consensus, but participation would not be so general; the chiefs would speak and act on behalf of their bands. Once a Council representing multiple bands reached a decision, each band was bound by the collective decision, unless the band chose to withdraw from the larger group. If the community decided in Council to go to war, a soldiers' lodge-a collection of men experienced in warfarewould form, with complete authority over the community for the duration of the war. ${ }^{437}$

The events of 1862 followed this general pattern. After the killings at Acton, when some of the young men began to urge war, Shakopee's band held a Council, followed by a multi-band Council in Taoyateduta's village and subsequent Councils among the Sissetons at the Yellow Medicine (Upper) Agency. ${ }^{438}$ It was at these Councils that the Dakota made the decision

434. Letter from J. Adv. Gen. Joseph Holt to Adj. Gen. (Jan. 29, 1875), in Letters Sent-JAG, NARG 153 (Entry 1). The Judge Advocate General was distinguishing the case of the Modoc leaders tried by military commission in 1873. See text accompanying notes 387-388 supra. But see Letter from J. Adv. Gen. Joseph Holt to Sec'y of War William Belknap (July 3, 1869), in Letters Sent-JAG, NARG 153 (Entry 1) (denying payment of claim to Cherokees for cattle taken by United States forces during Civil War; Cherokees could not be considered to be at war with the United States because they were in state of pupilage and dependence and were not independent communities).

435. DE VATTEL, supra note 370, bk. 3, §4; H. HALLECK, supra note 320 , at 351.

436. S. Pond, supra note 216 , at $66-69$. The following description is gleaned from discussions with present-day members of the Dakota nation.

437. The authority of the soldiers' lodge is similar to the authority of the military after a declaration of martial law. Sometimes a soldiers' lodge formed before the formal decision was made to go to war in part to attempt to influence the decision. The soldiers' lodge had no formal authority, however, until the Council decided on war. See note 436 supra.

438. See texts accompanying notes $22-25 \& 40$ supra. 
to go to war. With many Dakota having become "farmer-Indians" and assimilating American ways in the years preceding the war, however, the community itself was split. The farmer-Indians had formed their own band and were no longer part of Shakopee's or Taoyateduta's bands. When the decision to go to war was made, the farmer-Indians, who were assumed to be more sympathetic to the Americans, were not included at the Council meetings. Many of them were thus as surprised, angry, and frightened by the outbreak of the war as were the Americans. 439

The Dakota made the momentous decision to go to war rapidly, under the press of circumstances and despite the opposition of some of the leaders. Some Dakota may have felt that the decision to go to war was made without sufficient deliberation and consultation, contributing to a sense among some of the Dakota that the war was not a tribal decision, but rather a series of actions by a group of angry young men and those who chose to follow them. Despite the resulting opposition to the war by some of the Dakota, however, the forms of typical Dakota decisionmaking had been followed. Though the Dakota might ordinarily have taken more time to make such a decision and might have consulted more bands, Councils were held and group decisions were made, both to begin and to continue the fighting. These procedures were sufficient to gain recognition for the Dakota as legitimate belligerents. ${ }^{440}$

Even if the violence were considered to be the actions of a breakaway group, the men who fought may have been entitled to be treated as legitimate belligerents. Although the courts never decided what form of hostilities between the United States and an Indian nation would constitute an official war under the law of nations, the courts frequently considered a related question that sheds considerable light on this issue. In 1891, Congress passed the Indian Depredations Act, ${ }^{441}$ which provided for payment to individuals who proved that their property was taken or destroyed by "Indians belonging to any band, tribe, or nation, in amity with the United States." The United States would pay the claims from annuities or other funds owed to the tribe. ${ }^{443}$ When claims were made, the question necessarily arose whether the group of Indians that had taken or destroyed the property belonged to a "band, tribe or nation" that was "in amity" with the United States.

Almost invariably, the group in conflict was not a whole tribe or even a band, but a group that had broken from the rest and had independently decided to fight the Americans. In case after case, the Claims Court and then

439. See Cecilia Campbell Stay's Account, in Through Dakota Eyes, supra note 6, at 47-52; Good Star Woman's Recollections, supra note 21, at 52-53; Esther Wakeman's Reminiscences, in TrRough Dakota EyES, supra note 6, at 53-55; Joseph Coursolle's Story, supra note 19, at 57-58; Taopi's Statement, in Through Dakota EYEs, supra note 6, at 63-65.

440. See text accompanying note 435 supra.

441. Ch. 538, \& 1, 26 Stat. 851 (1891).

442. Id. at 851-52.

443. Id. $\S 6$, at 853. If no such funds were available, the United States would pay the claimant from the Treasury, but the amount would then be deducted from future payments to the tribe. Id. 
the Supreme Court determined that these groups had to be treated as distinct from their tribe. ${ }^{444}$ The courts invariably concluded that, although the tribe or nation remained at peace with the United States, the breakaway group had made an independent decision to go to war. Since the group that caused the injury was not "in amity with the United States," the property damage constituted an act of war and the claimant was not entitled to any recovery. 445

Of course, in these cases the courts were construing a statute, not applying international law. Moreover, the courts may have been motivated in part by a desire to protect the United States Treasury: If they found the warring group to be politically separate from the tribe, neither the tribe nor the United States would have to pay. 446 Nonetheless, the conclusions the courts reached about the political status of the warring groups seem to reflect the general understanding of Indian warfare shared by Congress, the military, and the general public. Thus, even if Taoyateduta and the Dakota who fought in 1862 did not act for the entire tribe, they should have been recognized as a politically separate band of belligerents entitled to favorable treatment under the laws of war.

\section{The Views of the Participants}

Although the historical and legal precedents consistently reflect that the Dakota were entitled to be treated as a sovereign nation fighting a war, the officials who controlled the events in 1862 did not treat them as such. For some purposes, at least, these individuals seemed to view the Dakota as sovereign, ${ }^{447}$ but in the aftermath of the war, the Americans involved in the

444. See Montoya v. United States, 180 U.S. 261 (1901); Scott v. United States, 33 Ct. Cl. 486, 493-94 (1898); Salois v. United States, 33 Ct. Cl. 326, 332-33 (1898); Conners v. United States, 33 Ct. Cl. 317, 320 (1898); Dobbs v. United States, 33 Ct. Cl. 308, 314-16 (1898).

445. In the most telling of these decisions, the Court of Claims reviewed the acts of what it called an "insurgent" group of Chiricahua Apaches led by Goyahkla (Geronimo), consisting of 22 men, 13 women, and 2 children. The group had no existence as a band prior to the outbreak of hostilities; had a military leader, not a hereditary chief, as their commander; and had no separate territory. The court nonetheless concluded that Goyahlla's small group was at war with the United States, independent of the much larger body of the Chiricahuas, who remained at peace. Scott, $33 \mathrm{Ct}$. Cl. at 494. The court accorded similar treatment to Tahmelapashme (Dull Knife) and Little Wolf, and to their followers, 320 members of two bands who had broken away from the rest of the Northen Cheyenne. Conners, $33 \mathrm{Ct}$. Cl. at 321. In considering (and rejecting) a reparations claim for injury caused by this group, the Court of Claims noted that these bands vere not individuals wandering from the main body, murdering and destroying while the main body remained in amity, but "an entire body waging armed resistance, with all its might and with all the ferocity of Indian warfare, against whatever power the United States could bring to bear upon them." Id.

446. See Steven A. Knecht, Tribal Status and the Indian Nonintercourse Act: An Alternative to the Montoya Definition of Tribe, 29 CATH. U.L. REV. 625, 629 (1980) (student author). The tribe remained primarily liable, but the United States Treasury was charged if no money was available from payments due or becoming due to the tribe from annuities or land sales, or from appropriations other than for "current and necessary support, subsistence and education." Indian Depredations Act, ch. 538, \& 6, 26 Stat. 851, 853 (1891).

447. See, e.g., Governor's Message, Pioneer Democrat, Sept. 10, 1862, at 4, col. 1 (Governor Ramsey's message to the state legislature referring to the "Dakota nation" and the "Sioux nation"); The Question of Responsibility. St. Paul Daily Press, Sept. 12, 1862, at 1, col. 2 (editorial noting that "[t]he Sioux Indians are not within the jurisdiction of the State of Minnesota, nor subject to its laws. 
events made clear that they believed the Dakota should be considered ordinary murderers and thieves. Sibley himself indicated that he regarded the Dakota "not . . . as entitled to be considered in the light of prisoners of war, but rather as outlaws and villains . . . "448 Senator Henry Rice agreed, saying that it would be an error to call the Dakota prisoners of war; in his opinion they were "murderers of the deepest dye."449 Although Governor Ramsey recognized the Indians "as independent nations, competent to declare war, to make laws for their own guidance, and to hold and dispose of property,"450 he also suggested that the Dakota should be treated as "visiting bands of murderers" and punished by the State of Minnesota. ${ }^{451}$ Senator Wilkinson and Representatives Aldrich and Windom wrote to President Lincoln expressing similar sentiments: "These Indians are called by some prisoners of war. There was no war about it. It was wholesale robbery, rape, murder. These Indians were not at war with their murdered victims." 452 Even Bishop Whipple, who was inclined to a more benevolent attitude, declined to consider the Dakota as sovereign and therefore entitled to carry on a war. ${ }^{453}$

The State authorities are excluded from any control over them or any responsibility for their conduct," but also stating that the Dakota were wards of the United States government); Letter from Right Reverend Bishop Whipple, St. Paul Daily Press, Dec. 4, 1862, at 4, col. 3 ("In all of our relations [with the Dakota] we have persistently carried out the idea that they were a sovereign people."); St. Paul Pioneer, Jan. 8, 1863, at 1, col. 1 (reporting another of Governor Ramsey's messages to the state legislature, in which he complained about "[t] he recognition of [the Dakota] as independent nations, competent to declare war, to make laws for their own guidance, and to hold and dispose of property").

448. Letter from Brig. Gen. Henry Sibley to Acting Ass't Adj. Gen. R. Selfridge (Dec. 22, 1862), in Letters and Telegrams Sent, NARG 393 (Entry 343). One month earlier, Sibley had written to Selfridge requesting his guidance regarding whether the Dakota were to be considered prisoners of war and thus entitled to complete rations. Letter from Brig. Gen. Henry Sibley to Ass't Adj. Gen. R. Selfridge (Nov. 29, 1862), in $i d$. Sibley seems never to have questioned the treatment of the Dakota as simple murderers for the purpose of the Commission trials. In a letter to Judge Advocate General Holt following the disapproval of the trial of Wowinape in 1863, Sibley challenged the application of a particular statute to trials, such as the Commission proceedings, involving "enlisted men or prisoners of war," see notes 184-185 supra, thus implicitly suggesting that the Dakota were prisoners of war. In view of his other actions and remarks, however, it is unlikely that Sibley fully considered this statement or meant to recognize in the Dakota any sovereign status entitling them to formal treatment as prisoners of war.

449. Letter from Sen. Henry Rice to Bishop Henry Whipple (Nov. 19, 1862), in Whipple Papers, MHS.

450. Annual Message of Governor Ramsey to the Legislature of Minnesota (Jan. 7, 1863), at 27 (on file with Stanford Law Review).

451. Id. at 29. In suggesting that the State might punish the Dakota, however, Ramsey continued to recognize the unusual status of the Dakota. The authority to try the Dakota that he claimed for the State emanated, he thought, from the state's power to engage in war independently of the United States when its own boundaries were invaded. Ramsey still saw the Dakota as a warring nation, not as a group of simple murderers acting individually and subject to the normal criminal jurisdiction of the State.

452. Letter from Sen. Morton Wilkinson and Reps. Cyrus Aldrich and William Windom to Pres. Abraham Lincoln, reprinted in S. EXEC. Doc. No. 7, supra note 116, at 4 (emphasis in original).

453. Letter from Bishop Henry Whipple to Sen. Henry Rice (Nov. 29, 1862), in Whipple Papers, MHS ("I said what I did simply to show how false a system was whose policy if carried out to its just conclusions left these savages as an independent nation and as such would have the right to engage in war, a doctrine I do not believe."). At least one person not directly involved with the 
These statements confirm what is evident from reading the transcripts of the trials: the Dakota were tried as common criminals, not as legitimate belligerents of a sovereign nation. The only proper charge against a belligerent is violation of the laws and customs of war. The Commission, instead, tried the Dakota on charges of murder, robbery, rape, and participation in the "outrages" on the frontier. Most of the Dakota brought before the Commission were charged with and convicted of murder solely for participating in battles, which is not an offense for legitimate belligerents captured in warfare. Although some individual Dakota might have committed acts in violation of the laws of war, ${ }^{454}$ the Commission made no attempt to identify those actions. The transcripts show that the Commission acted without recognition of the fact that most of the Dakota were guilty of nothing more than fighting in a war and that they were therefore guilty of no punishable offense.

\section{Violation OF THE LAWS OF WAR}

As members of a sovereign nation, the Dakota should not have been condemned for fighting in a war with the United States. Under the law of nations, however, they - as well as the American soldiers-would have been liable for acts that overstepped the bounds of proper warfare. We must therefore ask a final question: Do the trials reveal that any of the Dakota were guilty of violating the laws of war? Clearly, if the Dakota were sovereign and fighting a war, killing soldiers in battle would not be a violation. Similarly, once civilians took up arms and established themselves as de facto military units, as did the defenders at $\mathrm{New}$ UIm, they should be considered combatants and fair targets in the war. ${ }^{455}$

The killing of noncombatants is more problematic. Certainly it was the killing - and alleged mutilation-of civilians that provoked cries for revenge from the Minnesotans. It was also the killing of civilians that apparently persuaded President Lincoln to order execution of those who participated in "massacres" rather than in battles.

Although the proposition that noncombatants should be protected in wartime seems unobjectionable, it is far from clear what standard should have been used to judge the actions of the Dakota, because no precise standard existed in 1862. General Order 100,456 issued in early 1863 to guide the United States Army in its fight against the Confederacy, stated that the citizen of a hostile country is an enemy and is subject to the hardships of war, but that "[t]he principle [is] more and more acknowledged that the unarmed

events in Minnesota disagreed with these views and suggested a distinction of the sort $I$ have proposed in this article. V.D. Lowther, an attorney in Chicago, wrote to Whipple: "[R]ecognizing as we mistakenly do by Treaties the Indians as independent nations, not amenable to our laws, all of them that we have captured are entitled to be treated as Prisoners of War, entitled to their immunities ..." Letter from V. Lowther to Bishop Henry Whipple (Dec. 13, 1862), in Whipple Papers, MHS (emphasis in original).

454. See Part V infra.

455. H. HALLECK, supra note 320 , at 426 , 428; DE VATTEL, supra note 370, bl. 3, $\S \S 145$, $147,149$.

456. Gen. Order No. 100, supra note 334. 
citizen is to be spared in person, property, and honor as much as the exigencies of war will admit." 457 Similar sentiments were expressed by the major treatise writers of the time. ${ }^{458}$ But General Order No. 100 left ambiguous just what "the exigencies of war will admit": "Military necessity admits of all direct destruction of life or limb of armed enemies, and of other persons whose destruction is incidentally unavoidable in the armed contests of the war." 459 It consists "of those measures which are indispensable for securing the ends of the war, and which are lawful according to the modern law and usages of war." 460 The contemporary treatises were equally ambiguous: A belligerent nation has "the right to use such force as may be necessary, in order to obtain the object for which the war was undertaken .... [The subjects of the belligerent states], therefore, have no right to take the lives of non-combatants ... unless the same should be necessary for the object of the war."461

The general rule in 1862 , then, was that noncombatants should be protected but they might legitimately be injured or killed if the war required it and modern "law and usages of war" permitted it-a kind of common law standard to be gleaned from custom. 462 But in 1862 -indeed, until much later than $1862^{463}$ - there were no clear customs about when military necessity would justify killing civilians; perhaps the only certainty was that violence was directed at civilians, and was seldom punished. ${ }^{464}$ This proved

457. Id. § $1, \| 22$.

458. See, e.g., DE VATTEL, supra note 370 , bk. 3 , $\S \S 136-139,145 ;$ H. Grotius, supra note 370, at 323-31; H. HALIECK, supra note 320, at 412 . Halleck, it should be noted, was not only a scholar in the area of international law, publishing several editions of his treatise; he was also at various times the commanding general of the Union Army for the western theater, General-in-Chief of the Union armies, and chief of staff under General Grant. David Herbert Donald, Uniting The Republic, 1860-1877, in THE GREAT REPUBLIC 452, 460, 462 (1985). He was instrumental in promoting the promulgation of General Order 100.

459. Gen. Order No. 100, supra note 334, § 1, If 15.

460. Id., \& 1 , I 14.

461. H. HALLECK, supra note 320 , at 412 .

462. General Order 100 may have tried to move towards increased protection of civilians by limiting harm to them to situations in which it was "incidentally unavoidable," suggesting that direct attacks on civilians would be considered unacceptable even if "indispensible for securing the ends of the war." Gen. Order No. 100, supra note 334, $\S 1$, $\uparrow 14$. Without further contemporary explanation or application of these newly expressed terms, however, the precise standard by which to judge the Dakota remains unclear. See notes $463-467$ infra and accompanying text.

463. The international community did not reach any formal agreement on the protection of noncombatants until 1949. See Geneva Convention Relative to the Protection of Civilian Persons in Time of War, Aug. 12, 1949, 6 U.S.T. 3516, T.I.A.S. No. 3365, 75 U.N.T.S. 287. Earlier international agreements primarily concerned the treatment of combatants and prisoners of war. See I. DELUPIS, supra note 370, at 332-37. Even today, there remains significant controversy about the extent to which "military necessity" may justify behavior that would otherwise violate express provisions of the Geneva Convention on the treatment of civilians.

464. See, eg., Donald A. Wells, War Crimes and Laws of WAR 3-4 (1984); Best, supra note 378, at 29-31; Michael Howard, Temperamenta Belli: Can War Be Controlled, in ResTRAINTS ON WAR, supra note 370, at 1, 9-11; Donald Cameron Watt, Restraints on War in the Air Before 1945, in id. at 57, 57-58. Indeed, it was the absence of such international standards that raised questions about the legality of the Nuremberg and Tokyo War Crimes trials following World War II. See generally D. WELLS, supra, at 1-3, 71-72; William J. BosCh, JUDGMENT ON NUREMBERG: AMERICAN ATtTTUDes TOWARD tHe Major German War-Crime Trials 40-66 (1970); Charles E. Wyzanski, JR., WHEREaS-A Judge's Premises $164-90$ (1965). 
especially-although not uniquely-true in fighting between the United States and the Indian nations. ${ }^{465}$ The participants in the events of 1862 might therefore have had some difficulty articulating custom-based rules by which to judge the behavior of the Dakota.

Moreover, the Dakota, like other Indians, traditionally fought with methods substantially different from those of the Americans and Europeans. In particular, in intertribal Indian wars almost all members of the enemy nation-including women and children-were legitimate targets of attack, and captives were rarely taken. ${ }^{466}$ These practices were largely dictated by circumstances: the Indians had no prison camps in which to confine captives; women and older children, if taken, were likely to escape and bring vital information back to their own tribes; the fighting men could not effectively transport the younger children, and infants would likely die on the way. ${ }^{467}$ In arriving at its decisions, the Commission should have at least considered these differences in culture and military methods in any attempt to determine whether "military necessity" permitted killing noncombatants in the war.

Had the Commission tried to articulate rules of war by which to judge the Dakota, we could now evaluate whether the standards imposed were fair and reasonable, as articulated and applied. Unfortunately, the manner in which the trials were conducted does not permit such an inquiry. Even if now, more than a century later, we could somehow craft a nonanachronistic set of rules about treatment of noncombatants, the record compiled by the Commission would not be sufficient for application of those rules. The Commission allowed each defendant to speak and asked witnesses to identify the defendant and explain what they knew of his participation in the fighting, but the members did not inquire further once they had evidence of participation in the fighting. To the Commission, evidence that a defendant had shot a gun in battle with soldiers was just as damning as testimony that he had killed a family of settlers fleeing in a wagon. Because the Commission was determined to punish any Dakota who fought in any manner, it asked no questions about military necessity and made no effort to explore the circumstances of any of the killings.

President Lincoln stated that he made his decision to hang only thirtyeight of the 303 condemned Dakota in order to execute those involved in

465. See generally R. UTLEY \& W. WAShBURN, supra note 384; ROBERT WOOSTER, THE MilitaRy AND UNITED STATES INDIAN Policy 1865-1903, at 137-38, 141-42, 208-09 (1988) (U.S. army often violated traditional rules of warfare in fighting with Indians; Indian women and children were frequent targets); Don Higginbotham, The Early American Way of War: Reconnaissance and Appraisal, 44 WM. \& MARY Q. 230, 230-234 (1987) (reviewing work concluding that American wars were fought with a "strategy of annihilation," particularly in conflicts with Indians); Robert $M$. Utley, The Frontier Army: John Ford or Arthur Penn?, in Indian-WhITE Relations: A PersisTENT PARADOX 133, 133-34, 141 (J. Smith \& R. Kvasnicka eds. 1976) (U.S. army practiced total war against bands or tribes that resisted, killing many noncombatants).

466. See William W. Warren, History of the OjibWay People 102-07, 183-87, 224-27, 327-29, 352-53, 367 (1885 \& photo. reprint 1984); S. PoND, supra note 216, at 135.

467. S. PoND, supra note 216, at 135. 
"massacres" rather than "battles."468 Lincoln made these judgments, it seems, without recognizing the sovereignty of the Dakota, based solely on his desire to treat the Dakota more humanely and avoid the wholesale slaughter recommended by Sibley and Pope. Yet by distinguishing between "massacres" and "battles," Lincoln in effect attempted to draw the kind of line that would have been legitimate had the Dakota been acknowledged as sovereign and tried for violations of the laws of war. To some degree he was successful. The testimony-flawed though it may have been ${ }^{469}$ - tended to show that many of those who were hanged had killed men, women, and children in what appeared to be attacks on individuals in their homes or wagons, not as part of larger battles, ${ }^{470}$ or to have shot at individuals under such circumstances. ${ }^{471}$ Others were shown to have been in a group of Dakota, some of whom killed individuals in this manner ${ }^{472}$-although the liability of those accompanying the killers is questionable, as I have already suggested. ${ }^{473}$ Two were convicted of raping captive women. ${ }^{474}$

In other cases, however, Lincoln's choices are harder to understand. The Commission found Hdainyanka guilty of nothing more than leading the Dakota into battle and opposing the return of the hostages. ${ }^{475}$ Shoonkaska (White Dog) was found guilty only of using a stratagem at the battle at Redwood Ferry: he held Captain Marsh in conversation, allowing the Dakota to surround and fire upon the captain and his soldiers. ${ }^{476}$ Wahehud was convicted of killing a soldier, under circumstances not explained in the testimony. ${ }^{477}$ Several others may have been convicted for killings that occurred during the Battle of New Ulm, ${ }^{478}$ an attack on a strategically placed settle-

468. See notes 116-120 supra and accompanying text.

469. See notes 210-246 supra and accompanying text.

470. See Trial Transcripts, Case Nos. 6, 14, 15, 22, 67, 68, 69, 96, 115, 170, 210, 225, 264, 318, $333,342,373,377,382$.

471. See Trial Transcripts, Case Nos. 5, 138, 175.

472. See Trial Transcripts, Case No. 2 (defendant acted pleased when others said they killed two men; also convicted of rape), Case No. 4 (with group when settler killed; also convicted of rape), Case No. 24 (in party that killed settler, but defendant was chasing a girl who ran away when killing occurred), Case No. 155 (in group that killed settler), Case No. 254 (in group that shot at settlers on way to New Ulm), Case No. 279 (in group that fired on settlers at Beaver Creek), Case No. 327 (defendant seen in house where old man and two girls were killed), Case No. 359 (present when settler killed; saved white woman from death).

473. See text accompanying notes 219-221 supra.

474. See Trial Transeripts, Case Nos. $2,4$.

475. See Trial Transcripts, Case No. 19.

476. See Trial Transcript, Case No. 35; K. CARLEY, supra note 6, at 16; I. HeARD, supra note 6 , at 72-73. With no guarantees of safe passage having been given and no truce flag violated, it does not appear that these actions would violate the laws of war. Instead, they would be considered the ordinary kind of deception practiced to obtain advantage on the battlefield.

477. See Trial Transcripts, Case No. 12. Wahehud was also charged with and convicted of "making war upon the citizens of the United States," but the specifications listed only general participation in the war, and the testimony related only to the killing of the soldier. Id. It is against the law of war to kill a soldier who has surrendered, unless taking prisoners is impossible. H. HALLECK, supra note 320 , at $429-31,439-40$. The transcript gives no clues whether this is the kind of charge alleged.

478. See Trial Transcripts, Case Nos. 10, 178, 383. It is unclear from the evidence given whether these were isolated attacks not part of a general battle or actually part of the unified attack on New Ulm. 
ment defended by a group of citizen-soldiers. At least one Dalkota was omitted from the list of those to be hanged although his "crimes" were indistinguishable from some of those executed. 479

Lincoln tried to distinguish rationally between the Dakota who deserved retribution for their actions and those who did not. But because neither he nor the Military Commission recognized the sovereignty of the Dakota or attempted to define the proper bounds of warfare on the frontier, he constructed an imperfect line. Furthermore, the record he drew upon was insubstantial, the evidence was of questionable reliability, and the standards by which the Dakota were judged were unexpressed. Only the two convictions for rape present undeniable cases of violation of the laws of war. With respect to all the other cases, we cannot adequately judge the defendants. Because the participants did not ask the right questions, we cannot reconstruct the events sufficiently to determine whether the Dakota committed acts for which they might legitimately have been punished.

\section{UNDERSTANDING THE HISTORY}

We have seen that the trials of the Dakota were conducted unfairly in a variety of ways. The evidence was sparse, the tribunal was biased, the defendants were unrepresented in unfamiliar proceedings conducted in a foreign language, and authority for convening the tribunal was lacking. More fundamentally, neither the Military Commission nor the reviewing authorities recognized that they were dealing with the aftermath of a war fought with a sovereign nation and that the men who surrendered were entitled to treatment in accordance with that status.

A final question remains, however. The historical record shows that in no other instance in American history did the military respond to a war in this manner, though there were many opportunities. Why did it happen here?

First, the fact that the Dakota lived on a small strip of land, entirely surrounded by United States territory, must have led the Americans, consciously or unconsciously, to view the Dakota as less independent and less sovereign than Indian tribes that occupied larger tracts of land. ${ }^{480}$ The $\mathrm{Da}$ kota's growing dependence on the annuities paid annually by the United States government reinforced that perception. ${ }^{481}$ This attitude is reflected in the question asked over and over again in the trials of Wakanozanzan and Shakopee: Were they annuity Indians under the protection of the United

479. See Trial Transcripts, Case No. 3 (defendant in party that killed settler). There was testimony that he saved a white woman from death, and this may have saved his life, but others of those hanged had also protected captive women and were not spared. See note 223 supra.

480. I sense today the same reluctance among the general populace to view Indian tribes as sovereign, confined as they are to relatively small reservations surrounded by American territory.

481. These annuities were required payments for land sold pursuant to treaties and so represented, if anything, an affirmation of the sovereign status of the Dakota, since a country concludes treaties only with other nations, not with private groups. Whatever the legal consequences of receiving annuities, however, the Minnesotans apparently viewed the annuities as creating a dependent relationship. 
States? In effect, the Commission was asking whether the Dakota were dependent upon the United States and thus guilty of rebelling against their own government rather than warring against a foreign one.

A second likely reason for the treatment accorded the Dakota was the Americans' perception that the Dakota were no longer as different and separate as once they had been. When first encountering the Dakota on the frontier, the settlers considered them to be "savages" who could be forgiven their excesses because they did not know better. By 1862, however, the Americans viewed the Dakota as having betrayed a special relationship created by a dozen years of close contact between members of the two communities and substantial assimilation by some of the Dakota. ${ }^{482}$ The Dakota Reservation was an especially small geographical area, so the Dakota often traveled off the reservation and frequently visited the American settlements. Many of the settlers provided food, medicine, and volunteer services to the Dakota, particularly in times of special need. ${ }^{483}$

Missionaries had been active among the Dakota since the establishment of the first mission in 1835; although they reported few conversions before 1862, the clergy had a marked impact through their efforts to evangelize and acculturate the Dakota to Christian and "white men's ways." 484 Many intermarriages occurred between the two communities, and family ties thus bound them together. Substantial numbers of full-blood Dakota had adopted some American ways-cutting their hair and donning American clothesevents often accompanied by great pomp and ceremony by the American officials marking the transition. The farmer-Indians served as a visible reminder that some of the Dakota were settling into a very American-and very un-Dakotan-way of life. In 1856, a group of Dakota had broken entirely from the Dakota community and set up the highly touted "Hazlewood Republic," adopting an American-like constitution and laws.485 All these things combined to obscure from the Americans the extent to which most Dakota remained governed by their own traditions and to suggest to the Americans that the Dakota "knew better" and should be punished for their actions.

Some of the calls for vengeance on the Dakota reflected precisely this

482. See generally Gary Clayton ANDERson, Kinsmen of ANOTHER Kind: DakotaWHITE RELATIONS IN THE UPPER MISSISSIPPI VAIIEY, 1650-1862 (1984); Reginald Horsman, Indian and White Perceptions of an Expanding Republic: Minnesota in the Mid-Nineteenth Century (unpublished paper, on file with the Stanford Law Review); B. Forbes, supra note 123.

483. See Sweet, supra note 17, at 355-56, 369.

484. See generally B. Forbes, supra note 123 . Forbes reports that only 52 full-bloods and 15 mixed-bloods were members of the three mission churches on the eve of the war, but that the missionaries' impact on the Dakota community was much stronger than these figures suggest. Id. at 77. He believes that the tensions caused by the missionaries' inroads on traditional Dakota culture were themselves an important cause of the war. Id. at 259-67.

485. R. MEYER, supra note 6, at 102; B. Forbes, supra note 123, at 71. The Republic was established in 1856 by 17 Wahpeton, who, "wishing to place themselves under a separate chief and adopt all the habits of civilized 'life," signed a constitution and requested recognition from the federal government as a separate band. Id. (quoting the HazLEwOOD REPUBLIC CONST.). The Republic was recognized by the federal government, and by 1858 included 82 Dakota and mixedbloods. 
notion, which Sibley himself expressed in a letter he wrote to Bishop Whipple on December 7, 1862, seeking to justify the trials and executions:

A great public crime has been committed not by wild Indians who did not know better, but by men who have had advantages, some of religious teachings, all more or less of acquiring light, by long and intimate intercourse with white men, which rendered them entirely competent to judge of the criminality of the proceedings in which they are now implicated and who therefore do not deserve to be judged with the leniency, with which entirely wild and ignorant savages might have a claim to be treated. ${ }^{486}$

The extent of the killing and disruption caused by the Dakota and the nature of the Dakota attacks on a settled, permanent community further explain the American response. Hundreds of settlers were killed and more than ten thousand fled from their homes in fear for their lives. The Dakota destroyed homes and storehouses, and the settlers knew they would face the winter without sufficient supplies. Many Minnesotans personally knew someone who was killed in the fighting. In no other conflict with Indians, at least since colonial times, was a settled civilian community so thoroughly affected ${ }^{487}$-and all of it caused by a group most viewed as "civilized." Moreover, the attack came at a time when Minnesota, and the nation, felt particularly vulnerable as a result of the Civil War. ${ }^{488}$ Add the widespread belief, albeit unfounded, that most of the Dakota had engaged in wholesale rape and mutilation, and it becomes easier to understand the outpouring of rage and the disinclination to view the actions of the Dakota as justifiable warfare. At least one historian has suggested that the settlers' response to the

486. Letter from Brig. Gen. Henry Sibley to Bishop Henry Whipple (Dec. 7, 1862), in Whipple Papers, MHS. A printed memorial, sent to President Lincoln as be pondered the fate of the condemned Dakota, expressed similar sentiments:

Tame [the Indian], cultivate him, strive to Christianize him as you vill, and the sight of blood will in an instant call out the savage, wolfish, devilish instincts of the race. It is notorious that among the earliest and most murderous of the Sioux, in perpetrating their late massacre, were many of the "civilized Indians," so called, with their hair cut short, wearing white men's clothes, and dwelling in brick houses built for them by the government.

S. Exec. Doc. No. 7, supra note 116, at 5; see also Pioneer Democrat, Sept. 10, 1862, at 4 (Governor Ramsey's message to the legislature); Memorial for the Removal of the Winnebago Indians, Sept. 23, 1862 , reprinted in GENERAI AND Special Laws OF THE STATE OF MINNESOTA, EXTra SESSION of THE STATE Legislature COMmencing Sept. 9, 1862, at 92-93 ("[T]o live adjacent to those savages . . . is more than can reasonably be expected from a people who have lost all confidence in Indian integrity or Indian professions of friendship."); Reminiscence of Marcia Doughty Pike, Sunday Oregonian, Nov. 17, 1940, in Sioux Uprising Collections, MHS ("Had these red-skinned natives been engaged in open war, such as the law of races or of nations tolerate, their advocates might well have claimed for them the rights extended to prisoners of war. But these savages had declared no open war. They had secretly conspired against the lives of men, women and children in a time of peace when the hand of genuine friendship was extended for their relief.").

487. One historian called the United States-Dakota war "the most disastrous Indian uprising white Americans had experienced since the attacks of Opechancanough and Philip on the Virginia and Massachusetts frontiers two centuries before." ANGIE DEBO, A HISTORY OF THE INDIANS OF THE UNITED STATES 157 (1970).

488. In fact, there was suspicion that the Confederacy had incited the Dakota to war. See, e.g., Daily Tribune, Aug. 25, 1862, at 4, col. 4 ("The Sioux have doubtless been stimulated if not bribed to plunder and slaughter their white neighbors by White and Red villains set among them for this purpose by the Secessionists."); B. Forbes, supra note 123, at 255-59. 
war may also have been motivated by greed: Treating the Dakota as criminals allowed the United States summarily to remove all the Dakota from the state, thereby opening to settlement land that the Minnesotans had coveted for years. ${ }^{489}$

All of this may explain why the American community was unwilling to consider the Dakota as legitimate belligerents. Ultimately, however, it was Colonel Sibley, not the community, that decided to try the Dakota. It was he who first suggested, in his letters to General Pope, that he conduct trials and execute the guilty. Sibley had no prior experience in the military to suggest military commission trials as the proper avenue for punishing unfair tactics in warfare. But Sibley was a lawyer-indeed, the first lawyer and the first Justice of the Peace in the territory that became Minnesota. 490 His father had been Chief Justice of the Supreme Court of Michigan.491 Sibley was outraged at the conduct of the Dakota, personally offended by what he viewed as the rejection of friendship and assistance offered them, ${ }^{492}$ and keen to punish those he saw as murderers. His training as a lawyer, however, would suggest not that he punish the Dakota by removing them to a distant reservation, as was frequently done, but that he try them for their crimes. $\mathrm{He}$ expressed precisely such thoughts a dozen years earlier when, as delegate from the Territory of Minnesota, he introduced into Congress a bill for the extension of the laws of the United States over the Indian tribes of Minnesota and Oregon. "If the Indians must be punished," he said, "let the inflictions at least be regulated by law." 493 In providing trials for the Dakota in 1862 , he protected them, at least in his own mind, with due process, while ensuring that the guilty would be punished. ${ }^{494}$

\section{CoNCLUSION}

In one sense, Sibley may indeed have protected the Dakota. Without trials to satisfy the demand for retribution, the Minnesotans might well have

489. R. MEYER, supra note 6, at 124-25; $c f$. R. WOOSTER, supra note 465, at 51-55 (United States military policy often shaped by settlers' desire for Indian land). The Dakota were removed pursuant to statute rather than by treaty, as other Indian removals had been accomplished. See note 150 supra and accompanying text.

490. Robert J. Sheran \& Timothy J. Baland, The Law, Courts, and Lawyers in the Frontier Days of Minnesota: An Informal Legal History of the Years 1835 to 1865, 2 WM. MrTCHELL L. REv. 1, 6 (1976).

491. Id. at 14.

492. See note 486 supra and accompanying text.

493. Cong. Globe, 31st Cong., 1st Sess. 1507 (1850).

494. "I shall do full justice, but no more," he wrote to his wife. "I do not propose to murder any man, even a savage, who is shown to be innocent of the great transgression, or to permit the massacre of women and children." Letter from Brig. Gen. Henry Sibley to Mrs. Henry Sibley (Oct. 20,1862 ), in Sibley Papers, MHS. The role he played weighed heavily on his mind. Several days earlier he had written to his wife:

I have to review all the proceedings, and decide the fate of each individual. This power of

life, and death, is an awful thing to exercise, and when I think of more than three hundred

human beings are subject to that power, lodged in my hands, it makes me shudder. Still, duty must be performed, and judgment visited upon the guilty.

Letter from Brig. Gen. Henry Sibley to Mrs. Henry Sibley (Oct. 17, 1862), in Sibley Papers, MHS. 
carried out their threats to attack and kill the entire Dakota community. Moreover, by holding trials, Sibley left a more substantial record of the events of 1862 , providing greater opportunity for challenging the treatment of the Dakota. To the Dakota, however, who never doubted their own sovereignty, the trials were incomprehensible and an affront to their dignity. Because they gave a pretense of process with little actual fairness, with an underlying absence of authority, and with no recognition of Dakota sovereignty, the trials obscured the ultimate injustice to the Dakota nation.

The events of 1862 also suggest something more general about the limits of law in society. To fully serve its purposes, the law must do more than simply define boundaries of behavior and punish those who overstep the boundaries. Law must be more than the routine exercise of power. ${ }^{495}$ It must "guide and educate" those subject to it and validate itself ethically in the eyes of the governed as well as in the eyes of the ruling class. ${ }^{496}$ Groups that form the polity must either share the norms of behavior reflected in the law or accept that the system that produces those standards represents the best interests of the community of which they are a part, even if some individual rule is not consistent with their own self-interest. Law is justifiedand effective-only insofar as it reflects the community's shared values or is the product of a process viewed as legitimate by the governed.

In a relatively homogeneous society, or one in which cultural assimilation of new groups is the expectation and the reality, the law can easily fulfill this role. But those assumptions no longer apply in American society, if they ever did. We now recognize the very different realities that exist for culturally distinct subgroups of the governed. ${ }^{497}$ As we thus approach a more truly pluralistic society, acknowledging and (sometimes) valuing the separateness and individuality of the nation's constituent groups, the validity of duly enacted legal rules is no longer assured. ${ }^{498}$

The United States-Dakota War trials starkly illustrate the limits of law when the governors and the governed do not share an understanding, much less an acceptance, of the forms of law used and the norms applied. Because of the wide cultural gulf separating the Dakota from the Americans, the Dakota did not in 1862, and do not today, fully understand why trials were

495. See Mark Kelman, A Guide to Critical Legal Studies 263 (1987); Eugene GeNovese, Roll, JoRdan, Roll: The World the SLAVes MADE 27 (1974).

496. E. Genovese, supra note 495; see also Douglas Hay, Property, Authority and the Criminal Law, in Albion's Fatal Tree: CRIME AND SOCIETY IN EighteENTH-CeNTURY ENGLAND 17 (1975); M. KELMAN, supra note 495, at 262-68. But cf. Alan Hyde, The Concept of Legitimation in the Sociology of Law, 1983 WIS. L. REv. 379 (discussing generally the legitimacy of laws).

497. See generally KenNETH L. KARST, BelongIng to AMERICA: EQUAL CITIZENSHIP AND THE CONSTTIUTION (1989) (discussing United States' treatment of culturally distinct subgroups under the Constitution).

498. See, e.g., People v. Kimura, No. A-091133 (L.A. Super. Ct. 1985) (Japanese mother charged only with involuntary manslaughter in death of her two children where her actions would have only been deemed involuntary manslaughter in Japan); Nat'l L.J., Apr. 17, 1989, at 3, col. I (Chinese immigrant received lightest possible sentence for the murder of his wife after successfully asserting "cultural defense"-cultural factors lessening the defendant's responsibility for certain crimes). 
held, why some men were convicted and some were not, or why the thirtyeight, and later two more, were chosen to hang. If, as appears to be true, the United States intended the trials to "guide and educate" the Dakota-to confirm the acceptable standards of behavior and to serve as a warning about the consequences of future violations-then the trials failed to achieve their didactic purpose. The defendants and the rest of the Dakota community acquiesced in their treatment; they had no choice. ${ }^{499}$ But with no opportunity for the governed to understand the treatment they received, the trials and executions became an exercise of power, not law.

499. In this they seem less like the governed described by Genovese and Hay, see text accompanying note 496 supra, and much more like the criminal defendant who sits quietly through his trial and walks calmly, escorted to prolonged confinement, not because of any shared understanding of the rules but because of the "overwhelming array of violence ranged against him." See Robert M. Cover, Violence and the Word, 95 YAIE L.J. 1601, 1607 (1986). 
APPENDIX

The following is a list of abbreviations $I$ have used to refer to material contained at the National Archives and the Minnesota Historical Society:

\section{Documents at the National Archives}

Court Martial Cases, NARG 153, File NN3132

Indian Prisoners, NARG 94 (Entry 173)

Letters Rec'd, NARG 393 (Entry 340)

Letters Rec'd-Adj. Gen., NARG 94

Letters and Telegrams Sent, NARG 393 (Entry 343)

Letters Sent-Indian Expedition, NARG 393 (Entry 354)

Letters Sent-JAG, NARG 153 (Entry 1)

Military Orders, NARG 94
Court Martial Case Files; Records of the Immediate Office of the Judge Advocate General; Records of the Office of the Judge Advocate General (Army), 18081942; Record Group 153, National Archives, Washington, D.C.

Indian Prisoners, 1861-1865; Civil War, 1861-1865; Records Relating to Wars, 1812-1943; General Records of the Adjutant General's Ofice, Record Group 94 (Entry 173); National Archives, Washington, D.C.

Letters Received, 1862-1869; District of Minnesota, Nov. 1862-June 1873; Geographical Districts and Subdistricts; United States Army Continental Commands, 1821-1920, Record Group 393 (Entry 346); National Archives, Washington, D.C.

File 5I-1866; Sioux Uprising in Minnesota in 1862, 1862-1916; (National Archives Microfilm Publication M619, roll 483); Letters Received by the Ofifice of the Adjutant General, Main Series, 1861-1870; Records of the Adjutant General's Office, 1780s-1917, Record Group 94; National Archives, Washington, D.C.

Letters and Telegrams Sent, Nov. 1862-Oct. 1873; District of Minnesota, Nov. 1862-June 1873; Geographical Districts and Subdistricts; United States Army Continental Commands, 1821-1920, Record Group 393 (Entry 343); National Archives, Washington, D.C.

Letters Sent, June-Oct. 1862; Daily Journal of the Indian Expedition, June-Sept. 1863; District of Minnesota, Nov. 1862-June 1873; Geographical Districts and Subdistricts; United States Army Continental Commands, 1821-1920, Record Group 393 (Entry 354); National Archives, Washington, D.C.

Letters Sent, 1842-1889; Records of the Immediate Office of the Judge Advocate General; Records of the Office of the Judge Advocate General (Army), 18081942, Record Group 153 (Entry 1); National Archives, Washington, D.C.

Orders and Circulars, 1797-1910; Orders, 1797-1939; General Records of the Adjutant General's Office, Record Group 94; National Archives, Washington, D.C. 
Military Orders-Mexican War, NARG 94 (Entry 134)

Military Orders-Mexican War (Puebla), NARG 94 (Entry 134)

Military Orders-Mexican War (Volunteer Div.), NARG 94 (Entry 134)

Military Orders-Mexican War (Gen. Scott), NARG 94 (Entry 134)

Trial Transcripts
Orders, 1845-48; Mexican War, 1845-50; Records Relating to Wars, 1812-1943; General Records of the Adjutant General's Office, Record Group 94 (Entry 134); National Archives, Washington, D.C.

Mexican War Department of Puebla Orders and Special Orders, March-June 1848; Orders, 1845-48; Mexican War, 1845-50; Records Relating to Wars, 1812-1943; General Records of the Adjutant General's Office, Record Group 94 (Entry 134); National Archives, Washington, D.C.

General and Special Orders, February 18-December 18, 1847, Mexican War Volunteer Division Issued and Received; Orders, 1845-48; Mexican War, 1845-50; Records Relating to Wars, 1812-1943; General Records of the Adjutant General's Office, Record Group 94 (Entry 134); National Archives, Washington, D.C.

Worth's and Scott's Command Orders, Issued and Received, June 1846-July 1847; Orders, 1845-48; Mexican War, 1845-50; Records Relating to Wars, 1812-1943; General Records of the Adjutant General's Office, Record Group 94 (Entry 134); National Archives, Washington, D.C.

Senate Records 37A-F2, Original Transcripts of the Records of Trials of Certain Sioux Indians Charged with Barbarities in the State of Minnesota; National Archives, Washington, D.C.

\section{Documents at the Minnesota Historical Society}

ABCFM Papers, MHS Papers of the American Board of Commissioners for Foreign Missions, 1827-1878; File BA10.A512b, Minnesota Historical Society, St. Paul, Minnesota.

Riggs Letters, WPAChippewa County Project, MHS

Riggs Papers, MHS

Sibley Papers, MHS [microfilm]

Sioux Uprising Collection, MHS

Sioux War Trials, MHS P1423
Letters of Stephen R. Riggs; Works Progress Administration, Chippewa County Museum Project 1465, 1936-37; File FF612.W9C5 (vol. 13), Minnesota Historical Society, St. Paul, Minnesota.

Stephen Return Riggs and Family Papers, 1837-1958; File P727, Minnesota Historical Society, St. Paul, Minnesota.

Henry Hastings Sibley Papers, 1815-1930; File M164, Minnesota Historical Society, St. Paul, Minnesota.

Sioux Uprising Collection; File P1369, Minnesota Historical Society, St. Paul, Minnesota.

U.S. Army; Military Commission, Sioux War Trials, 1862; Trial Transcripts; File P1423, Minnesota Historical Society, St. Paul, Minnesota. 
Whipple Papers, MHS

Henry Benjamin Whipple Papers, 1833-1934; File P823, Minnesota Historical Society, St. Paul, Minnesota. 